\title{
- Corpo, A Artista e A Feiticeira
}

\author{
Kim Cavalcante
}




\section{Instruções}

$1^{\circ}$ Ver os vídeos e fotografias das performances Intervalo (2016) Saia Sonora/ O mar não encena (2016), Experimentos de Jardim (2016) e Artista Feiticeira (2017) .

$2^{\circ}$ Ver as 125 lâminas no arquivo Laminas_digital. Originalmente estas lâminas são impressas em transparências. Algumas delas contém intervenções.

$3^{\circ}$ Ler o arquivo Escritos II_digital. 


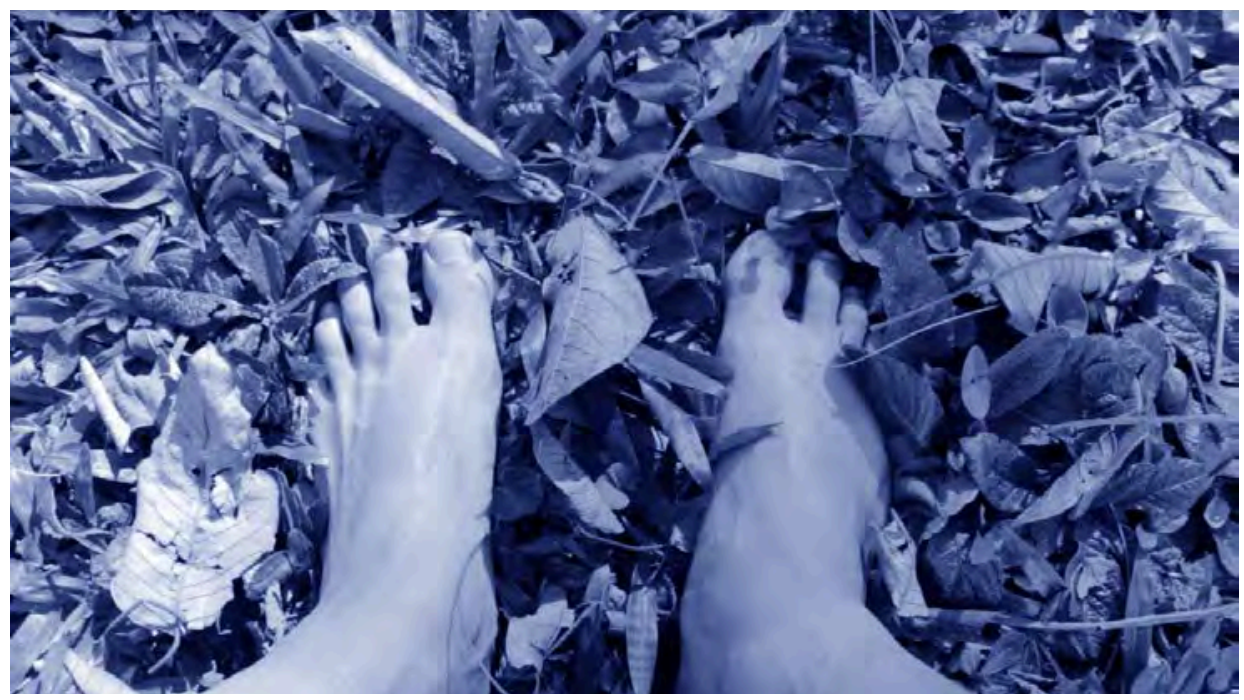




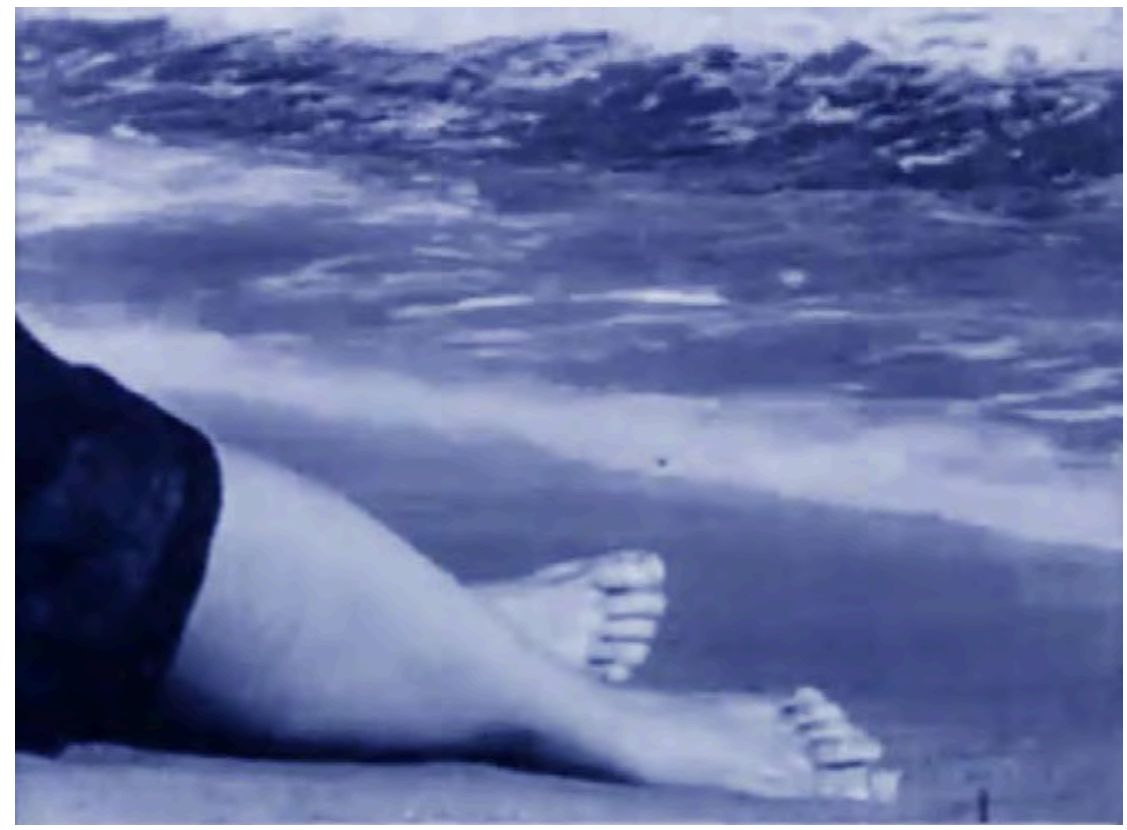




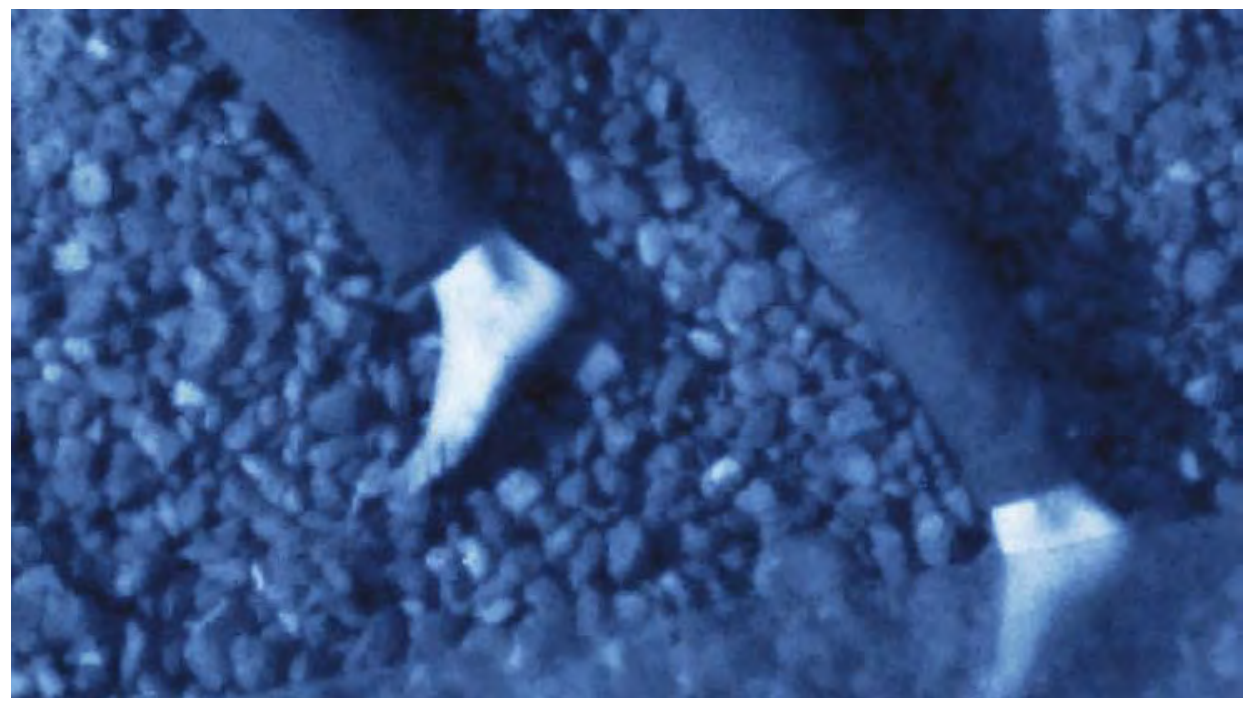


Intervalo

quebra no tempo

quebra no espaço

nuances sutilezas

delicadezas

pequenos grandes momentos

interrupção

No momento da realização, o foco era a descoberta: o que eu poderia sentir ali naquele contato?

Improvisação: tempo real e verdadeiro no tempo que é. Não ensaio.

Pulsações latentes dos pés. Daquele instante exato pulsação vida. 
De fato há prazer nisso. Em descobrir meu pé naquele lugar.

As sensações, os sons das folhas conforme o movimento dos meu pés. As marcas deixadas.

O gelado da terra que não está na superfície.

O próprio movimento dos meus pés. Que caminho é esse? Por que ele se movimenta assim?

A entrega ao desconhecido, mas que sabe que vai revelar algo, algum conhecimento, nem que este seja o próprio conhecimento de como posso estar ali, que caminhos meu corpo faz, mesmo sem sentido aparentemente.

Lugares a serem descobertos.

Tempo, espaço no tempo, do tempo mais próximo do real da experiência. Imersão nos movimentos e sensações, e extra sensações,

Tato, som.

Por que tanto tempo fazendo isso? movimentando os pés? o que acontece? Nada é o que acontece. 
Pés ali descobrindo o que há ali. O quê meus pés fazem aqui?

Quando você se solta, mesmo tendo um repertório, a diversão está justamente no que você faz naquele momento. Qual sequência? Em que lugar você põe seus pés agora? Qual vai ser seu recado desta vez?

Nós já sabemos andar, já sabemos por um pé em seguida do outro. Somos capazes de não saber e arriscar descobertas nisso? Sentindo prazer?

Momento de nada.

Tátil.

Contrações corporais que se concentram e tensionam nos pés. Som de cada sutil movimento, seu som.

Som do atrito com a terra, com as folhas, das folhas com a terra, da terra com as folhas, das folhas com os pés, dos pés com os pés. 
A visão dos pés e, por alguns momentos, das pernas e entre as pernas, pois a visão é minha e minha cabeça fica no meio das pernas.

Poucos estão acostumados a utilizar o corpo como fonte de prazer. Poucos utilizam mais que três posições e nem sempre elas significam prazer. Visão limitada do corpo. Alguns encontram o prazer do corpo somente no sexo. Não sentem prazer em sentir a água escorregando pela língua, não sentem prazer na variação de temperatura, não sentem prazer em revirar as mãos de modo a fechar os olhos e não conseguir deduzir em que posição está, sem ver. Não sentem prazer em simplesmente não saber e deixar o porvir.

Sempre achei que a dança tinha um elo direto com o sexo.

Para mim, dançar é um prazer imenso, como o sexo e como comer. São todos momentos de descoberta e de desfrute.

Quando eu danço eu não sei como vai ser. Vai depender da música, e da minha energia naquele momento. Digo energia não de um modo abstrato, mas justamente da frequência e intensidade que posso assumir naquele momento.

A mesma música pode suscitar em momentos diferentes movimentos e intenções diversas. E o recado é diferente em cada um destes momentos. Depende justamente da sequência de movimentos feitos naquele momento.

Por movimento, enten do também as diferentes frequências de respiração, diferentes olhares, as pausas, os silêncios, as deixas, e os movimentos que não fiz.

\section{- RGCabo:}

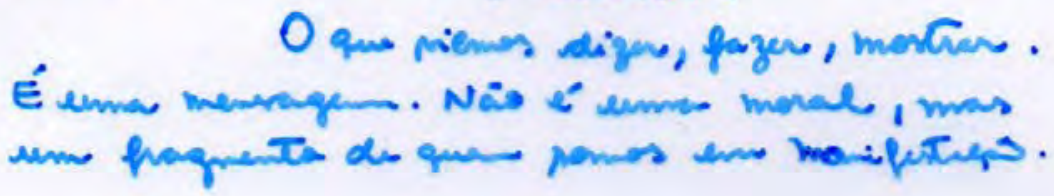


Por isso é uma sequência, um conjunto. Quando deixo de fazer, também há uma intenção. O não saber desenrolado a partir de um movimento já sabido, é um aprofundamento do movimento, das descobertas. É um desvelamento do movimento consigo mesmo e você se torna cada vez mais parte dele e ele de você. Se torna um segredo. Um feitiço. Você passa a experienciar aquilo que já sabe, o que é capaz de fazer e para que deseja fazer. O que não é para você, mas o que é seu. A partir daí, sabe quando deve e quando não deve, sempre correndo o risco de errar, e por isso sempre procurando a beleza de acertar no desconhecido. Passa a dançar com o desconhecido, aprende a dançar com ele e sua beleza. Sua magia passa a crescer com ele.

O corpo pulsa, mas a maioria não está acostumado a assumir a pulsação. Necessita pegar o ônibus, seguir movimentos para estar no ônibus. Necessita estar no trabalho, e seguir movimentos para estar no trabalho. Vai para a aula de dança, e seguir os passos da dança. Isso não é pulsação, é passo, pé de dança, protocolo.

Pulsação é algo que varia, mesmo que repita o mesmo passo. É infinito. E viver essa infinitude é sua beleza. 
O intervalo é um tempo suspenso. Um não tempo. $O$ tempo do não acontecimento, da não ação. É o entretempo entre um movimento e outro. Por isso, o intervalo tem o poder de dilatação. Nele, qualquer movimento simples é ampliado à percepção. Mas a entrada no intervalo está condicionada à pausa, ao silêncio do movimento, em que todas as ações são novas e novamente, ineditamente perceptiveis, incorporando justamente aquilo que sempre vemos, mas não conhecemos. O intervalo torna o micro em macro. E proporciona uma nova percepção, além da visão, olfato, tato e audição.

O intervalo é um rastro que contém milhares de acontecimentos. É uma investigação do rastro, dos tempos suspensos, do deslocamento do tempo, assim como é o espectro. $O$ intervalo é a vivência do espectro $A$ imersão no tempo e espaço do espectro. Rastreamepto de tudo que nele existe. Aquilo que em imagens em moyimento são vistos como rastros, disformes, não absolutos, são um mundo inteiro. Com o intervalo é possível descobrir que os mundos espectrais são tangíveis. O intervalo mostra a potência do corpo de captar e vivenciar este não tempo que fambém tem matéria e ação.
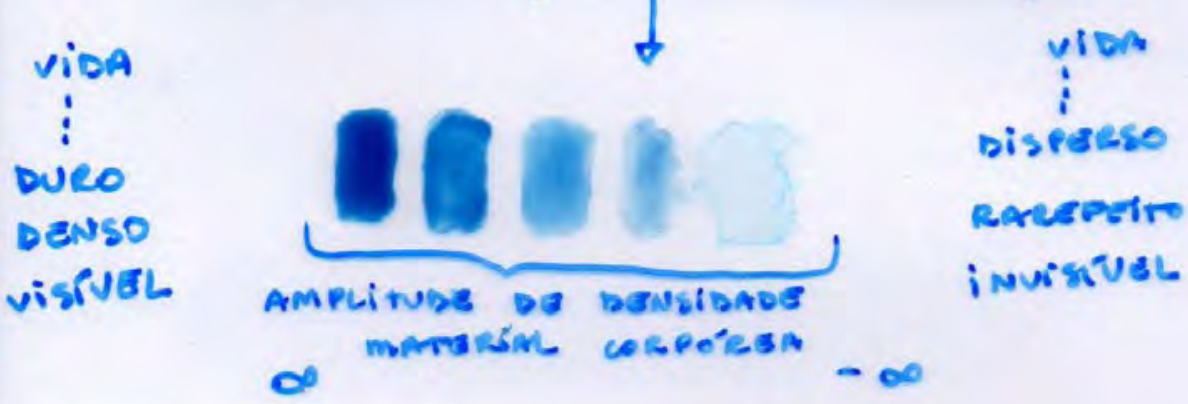
meditação em movimento

corpo contato

tátil, sopro, poeira

rastro

fricção

ritmo e compasso em que se lançam ao acaso do caos as folhas

avisos

gritos pássaros

ar que soa em avião

infrassons

espaçamentos preenchidos no acontecer dos rastros das folhas ar que ocupa

em meu corpo elas se encontraram

por acaso em muitos pontos

e o som se fez contato

matéria da folha que marca o espaço e o compasso

medida

folha marcada, folha não marcada

onde pisou, onde retrocedeu

suco espreme

tira do vazio sua essência em caldo

líquido

vazio que escorre

in loco

corpo que estrala na pausa 


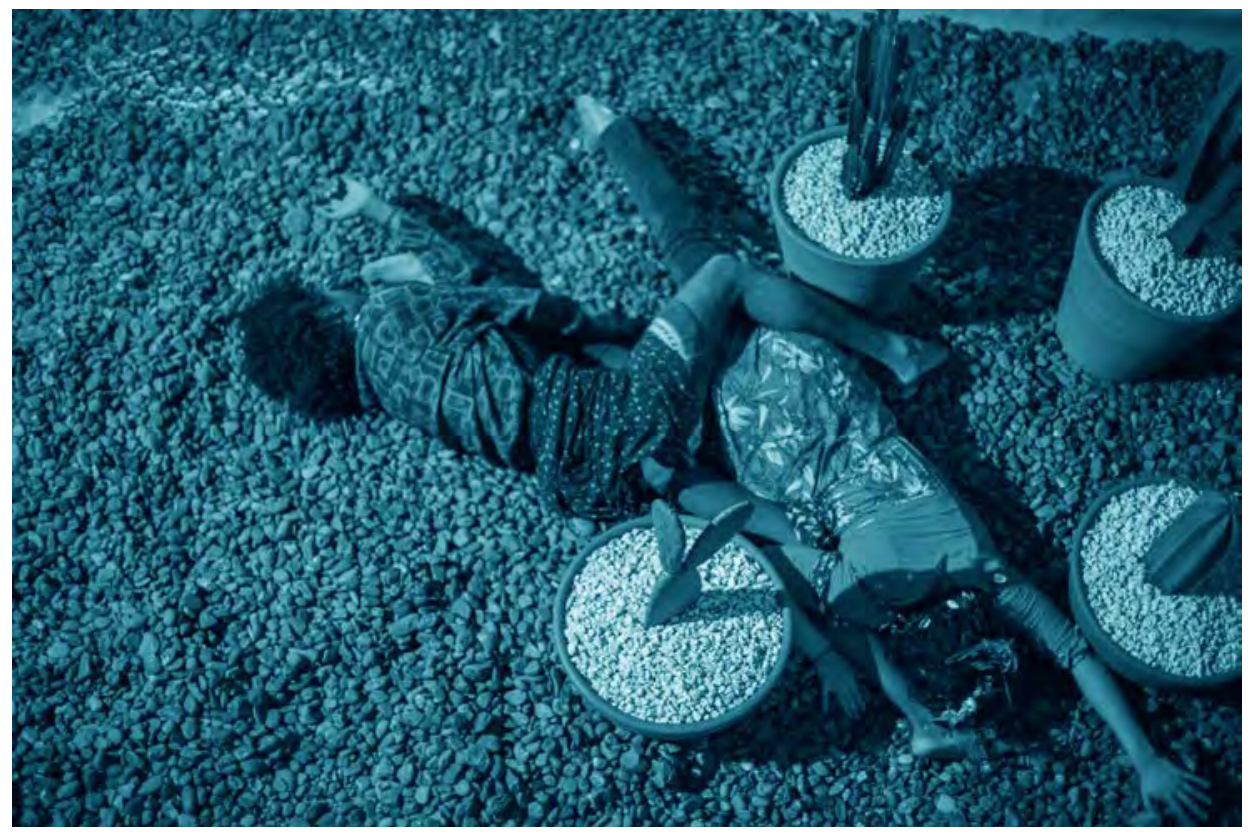




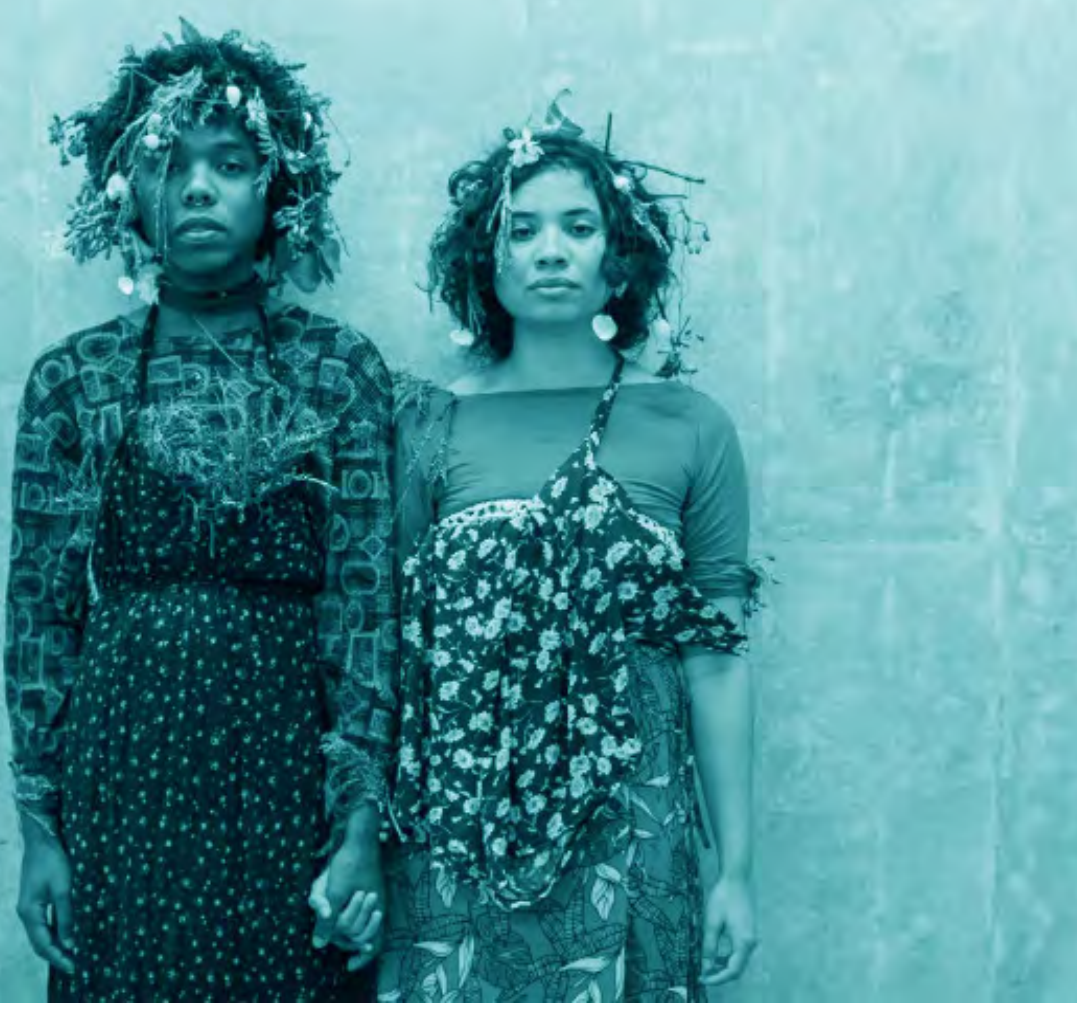


Conheci Castiel e seu trabalho durante minha participação como artista imersa no Afrotranscendence 2016 na Red Bull Station - uma rede interdisciplinar que incentiva e promove experimentação, pesquisa, conhecimento e a produção do pensamento crítico e artístico cultural afro-brasileiro.

Castiel e eu nos identificamos através de nossos trabalhos. Ambas desenvolvemos nossa poética em intersecção com corpo, natureza, gênero, decolonialismo e questões étnico raciais. Também com o terror. Trabalhamos com performance, fotografia, vídeo e objetos, tendo como centro nosso próprio corpo.

Castiel se auto define como bixa, preta, terrorista de gêneros racializados, localizando-se entre a psicologia e a arte. É artista e estudante de psicologia na Universidade Federal do Espirito Santo. Estabelece uma relação poética instigante com sua avó, usando suas roupas. Eu me apaixonei por Castiel. 
Eu havia sido escalada para outro grupo, com artistas incríveis. Mas essa seria uma oportunidade de fazer um trabalho com Castiel que eu não poderia perder.

Já havia falado muito rapidamente com Castiel sobre a possibilidade de fazermos algo juntas. Pela manhã cedo, levei roupas, recolhi plantas e the falei sobre minha ideia de usar o jardim.

Fiquei instigada pela possibilidade de fundir nossos trabalhos, pois Castiel trabalha com roupas-próteses e eu, com aparatos corporais. Isso abriu para mim também a possibilidade trabalhar intersecções com a moda.

A proposta que recebemos de utilizar o prédio da Red Bull Station, localizado no Anhagabaú, foi para mim um desafio de intervenção num espaço urbano, uma natureza no espaço urbano, num prédio no centro de São Paulo.

A nossa proposta de trabalho então se constituiu num cruzamento de interesses por moda, roupa, revistas, imagens de moda, ensaios fotográficos de moda, o espaço do jardim, a natureza, performance e instalação.

Senti com Castiel uma sintonia muito grande. Quando conversávamos sobre a ação, tudo parecia muito simples e fácil. Assim como eu, ela se entrega muito facilmente à ação. Tudo fluía muito bem, mesmo que sem muita preparação. 
A ideia era fazer um jardim. Nós seríamos o jardim.

Gabriel Hilair, criador de Dudús - uma plataforma digital colaborativa de divulgação de artistas negros -, estava aí ajudando a mim e a Castiel a criar nossas camadas de tecidos e diversos elementos.

Eu havia conhecido Gabriel através do Afrotranscendence 2016. Melhor, eu o havia conhecido pelas suas roupas simplesmente incríveis que ele criava. Meu encontro com sua produção, assim como com Castiel, fazia-me perceber diálogos possíveis entre meu trabalho, a vestimenta e a moda.

Eu havia levado uma série de roupas de tecidos herbários e florais. Levei conchas, óleos essenciais, linhas, flores, plantas. Castiel também levou tecidos, roupas, e colheu algumas plantas.

Tudo aconteceu numa lógica do improviso. Gabriel nos ajudava a nos vestir. Trabalhamos com sobreposições de roupas e estampas. Eu deixei essa parte com Gabriel e Castiel, pois era seu talento. Apenas me entreguei. Castiel usava roupas de sua avó e roupas minhas. Tínhamos plantas em nossas roupas e nos cabelos, onde também penduramos conchas.

Eu havia preparado um spray com óleos essenciais de flores e ervas para nosso jardim, para que sua percepção se desse de outras maneiras, sutis, que não a visual, já que era de sua natureza arquitetônica ser um jardim escondido. Mas ao longo dos preparativos o spray simplesmente desapareceu, e não pudemos usá-lo. Eu e Castiel ficamos muito chateadas, mas sabíamos que não podíamos perder o foco da ação.

Tudo aconteceu sem um planejamento metódico. Mas tudo parecia já estar arranjado. Fluidez. 
Por que o jardim? O jardim porque era um espaço real, com características próprias, uma espécie de site specific do edifício, que poderia ser o lugar de uma instalação. Era para mim ali um jardim morto, meio escondido. Aquele tipo de espaço que sobra, mas que não é completamente invisível.

Haviam ali pedras de jardim e cinco vasos de cactos. Apenas isso. uma oportunidade de trabalhar com uma outra natureza: uma natureza urbana, montada, de um edifício e de um espaço um tanto cinza, aparentemente inerte.

A grande quantidade de pedras me chamava a atenção, pois gosto de trabalhar com elementos e movimentos sutis e com seu som. Era uma jardim grande em metros quadrados, mas morto até então.

Limpamos o jardim, de papéis, bitucas de cigarro e etc. Pela manhã as pedras estavam muito quentes, por isso não foi possível fazer testes. Era impossível deitar sobre as pedras sem se queimar. 
Diferente de outros trabalhos que aconteciam naquela noite na Red Bull Station, durante o Afrotranscendence, dentro de um percurso no qual Benjamim Abras - um dos mentores da imersão artística - conduzia o público a diferentes pontos onde aconteciam diferentes ações dos imersos, eu e Castiel decidimos simplesmente permanecer como um lugar - um jardim.

Decidimos que seria diferente dos outros trabalhos nos quais as pessoas eram levadas até o ponto onde estes estavam acontecendo, então permaneciam por um tempo, até o fim do trabalho e depois seguiam para o próximo.

O espaço do jardim era abaixo do nível dos pés das pessoas. Eu e Castiel havíamos utilizado uma escada para descer até lá. Para ser visto como algo além de um buraco, havia a necessidade de um olhar mais atento para o jardim e havíamos decidido que aquela condução não deveria ser aplicada ao nosso trabalho. Em Experimentos de Jardim, o público somente passaria pela performance junto a Benjamim. Apenas permaneceria quem olhasse e percebesse que algo ali acontecia, para então permanecer, se assim desejasse.

Essa decisão diz muito sobre o trabalho. Pensamos que era um risco e talvez até um erro. Mas decidimos viver isso: as vidas mínimas, os movimento mínimos, o grande que está no mínimo.

O trabalho trata da visão e seu alcance, do que é visível e o que é invisível; da vida que existe e não se vê, por algum motivo. Qual o alcance do nosso olhar? porque acreditamos tanto naquilo que vemos? E acreditamos naquilo que não vemos?

A matéria escura junto com a energia escura constitui $95,1 \%$ do conteúdo do universo. É a matéria que não interage com a luz, mas interage gravitacionalmente com a matéria conhecida. Ela não é visível, mas existe. Não se sabe como surge, ou em que pode se transformar.

Assim, seríamos eu e Castiel. Nós seríamos plantas, dança, vida, movimento. Mesmo que ninguém nos visse, ainda assim seríamos e estaríamos alí, de fato. 
Enquanto já haviam começado as apresentações na nossa última noite, eu e Castiel apenas estávamos ali, sendo o jardim. Benjamim Abras conduzia o público pelos diferentes espaços nos quais os artistas se apresentavam, e nós estávamos apenas ali, 0 jardim.

De noite, o jardim estava iluminado. Começamos em meio aos cactos. Nossos movimentos e respiração se encaminhavam pela interação entre eu Castiel e as pedras, ora pelo olhar, ora entrar e sair do ar, pelo som, pelo contato.

Nossos movimentos em meio às pedras eram muitas vezes pesados. Penetrar em meio a elas era fazer um caminho. Era um processo árduo que demandava muita energia. A conexão, entre eu e Castiel, que acontecia de diversas maneiras, em algum momento se tornou intensa. Nós nos embrenhávamos. Eu, de olhos fechados, já não sabia o que era braço, o que era perna, somente sentia deslizes. Não havia mais pênis nem vagina. A pulsação dos movimentos e da respiração variavam num ritmo próprio, sem coordenadas. E naquele momento eu senti a relação entre a vida e o sexo. Um sexo autêntico, não precisa de penetração, precisa de encontro e de perda. Perda de si, perda do controle, perda da noção de sítio, para que o encontro possa acontecer e se realizar como encontro, uma outra coisa, um outro ser, uma criação, outra vida.

Essa outra vida pode durar segundos, horas, anos e se remodelar a cada encontro, ou num mesmo encontro. 
Era difícil muitas vezes chegar até um lugar hospedável, onde eu pudesse ter um espaço para meu corpo crescer. Em meio as pedras, tudo é mais inóspito, e o barulho do meu caminho em atrito com elas denunciava isso.

Quando minhas pontas encontravam o vaso depois de percorrer sofridamente grande parte do jardim -, eu comecei a sentir a preparação, o recuo que antecede $o$ ataque. Eu havia encontrado um lugar para mim. Mas perscrutar leva tempo. Fixar-se requer cuidado.

O recuo que antecede o ataque... Neste momento eu entendi: porque muitas vezes as danças dos orixás são daquela maneira. 


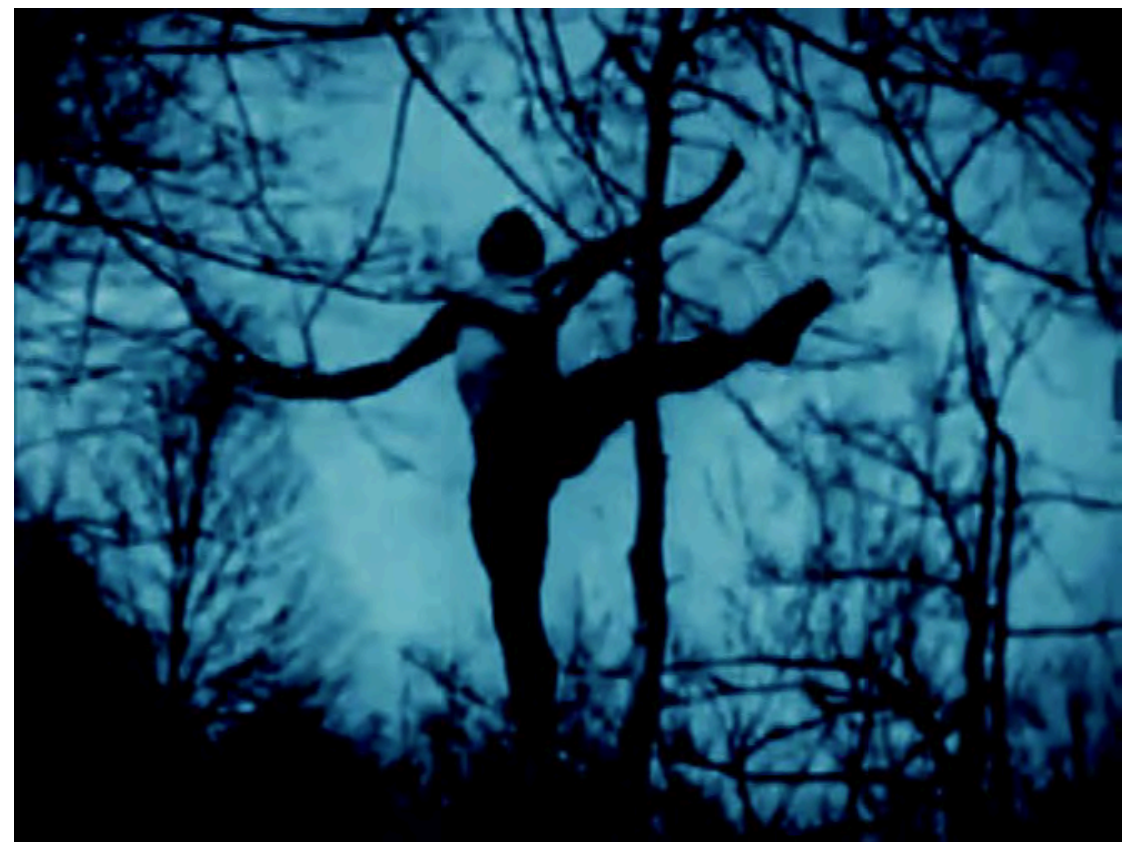


Uno busca por su lugar, donde pueda ser. Y ser significa una preparación antes de ser, una preparación para ser. Uno sólo es siendo. Pero, ¿cuál es el lugar fértil para que uno sea? Nadie ni nada va a ser igual en lugares diferentes. Uno busca por el mejor lugar para ser quién es en verdad, para que uno sea en verdad y pueda crecer nutriéndose de lo mejor que pueda ser, alli reside su belleza.

tada e imprevisible, porque to son en verdad ellos mismos - lo mejor que pueden ser. Eso nos enseña la belleza de cada uno, su espacio y su nutrición al crecer, al buscar su lugar propio. Todos tienen su lugar al sol. Las plantas buscan por su lugar al sol; ya sea que prefieran una sombra, su lugar está alli, y solo alli pueden habitar, crecer, dar frutos, flores y morir, retornando al suelo y nutriendo a todos a su alrededor.

$\rightarrow$ DANCYA:

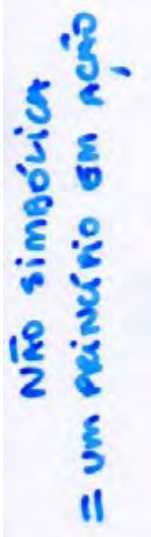

Eu perscrutava o vaso de pedras brancas do cactos e meu corpo soube antes de mim que aquele era o lugar, o melhor lugar para mim. Eu estudava com as mãos, com os braços, com o tronco, com meu estômago, com os tubos das narinas, a melhor recepção para mim naquele habitat. 
Percebo muitos dos trabalhos que realizo no sentido de um processo artístico capaz de provocar experiências em muitos níveis, dos quais não se tem muito controle. A magia é assim. O princípio básico é que não sabemos de nada. $O$ que sabemos, sabemos pelo contato e aprendizado através de experiências com diversas realidades. O que significa que lidamos não somente com espíritos, não somente com seres mortos, que um dia viveram, mas com muitas categorias de seres, que não conhecemos o limite.

Por isso, o trabalho artístico, assim como a magia, requer cuidados. Requer responsabilidade e, antes de mais nada, requer verdade e coração puro em seu fazer.

O coração puro não é o coração inocente. É justamente o conhecimento e a consciência de que tudo pode sair bem, como pode sair mal que torna a pessoa sabida da preponderância da verdade e do coração puro. A pureza vem da verdade no amor. $\mathrm{Na}$ espiritualidade não existe mentira. Independente do que se diga ou pareça ser, tudo que vai volta, e aí só existe a verdade.

Desse modo, a verdade e o coração puro protegem o artista em seu fazer. A artista feiticeira quando age dentro destes princípios não precisa ter medo.

Alguns podem se perguntar se isso não seria "brincar" com a espiritualidade. Não. Isso não é brincar com a espiritualidade. A espiritualidade está em tudo. Para lidar na dimensão da espiritualidade, basta estar conectada a ela. Sim conectada. Pois é um canal. Como uma televisão. Você pode estar conectada ao canal $x$ ou ao canal $y$, ou com os dois simultaneamente. E o canal $x$ e $y$ existem e operam, interagem, independente de você, mesmo que você não esteja conectado a eles. Mas para operar com eles, deve-se estar conectada. Caso contrário, fará tudo sem um intuito definido. 
É incrível como a espiritualidade está em tudo. Está nas pessoas que se conhece, nos lugares onde se vai, na comida que se come.

Neste trabalho com Castiel, estávamos trabalhando questões de gênero, o espaço, o jardim, as plantas, mas a dimensão espiritual estava presente no seu modo de fazer, no seu desenrolar, nos acontecimentos, em nosso corpo e fora dele.

Castiel havia participado de outro trabalho em que costurava sobre roupas de um querido amigo da imersão. Eram roupas do Candomblé. Ele ficou muito preocupado, pois sentia a seriedade do trabalho ao lidar com aquelas vestimentas, mas não conseguia muito bem definir seu lugar naquilo, se o que estava fazendo era apropriado, ou inapropriado, se era seguro ou não. Não tivemos tempo para conversar sobre isso, o que teria sido muito interessante, principalmente se o fizéssemos com os artistas imersos Nega Duda e Iwintolá (Rafael Ribeiro) que são do Candomblé e fizeram ações nas quais essa tradição e ação ritual eram preponderantes.

Mas em meio a tudo isso, depois de vermos nossos portfolios, de conversarmos sobre nossos trabalhos, de nos vestirmos juntos, de conversarmos sobre ervas, florais e óleos essenciais, Castiel me fez uma das melhores perguntas: "o que é você"?

Eu interpretei a pergunta: "Como pode alguém ser artista e também ser feiticeira, de fato e não só na poesia?"

Trato justamente de como que essa dimensão poética é capaz de proporcionar experiências espirituais de fato; como é possível tratar destas questões; como é possível abordá-las no universo da arte, como elas se configuram na arte e na história da arte.

Quando são utilizados processos artísticos, a história da arte e processos ritualísticos espirituais num só momento, o que acontece? 


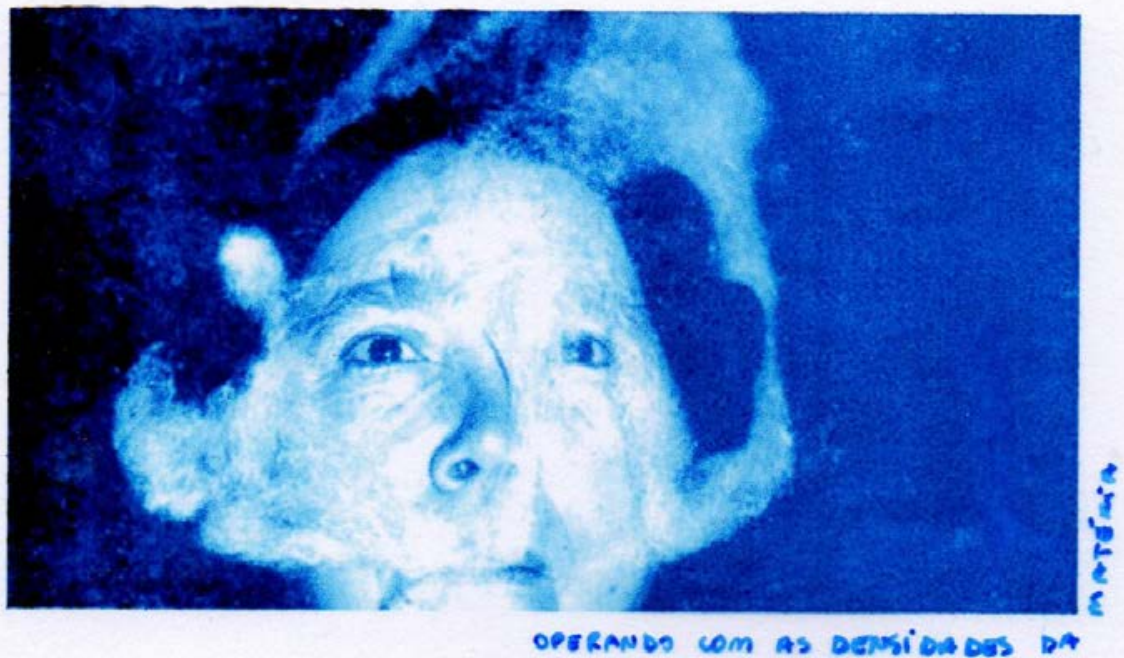




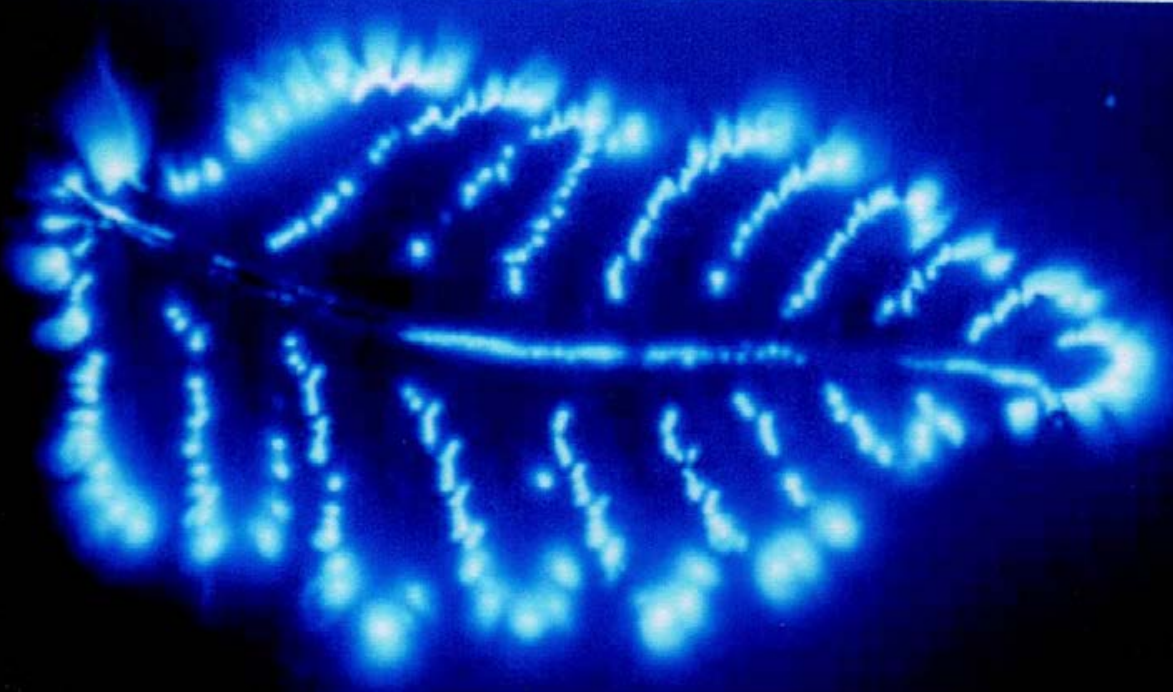

AURA 
Espectros de densidade e não densidade.

Se vê, se sente, é porque toca e atravessa, Mesmo à distância. 
se revela pelo negativo

como pode existir num momento e depois não

se transfere

pode ser condensada num momento e não o ser no outro

ser matéria visível e depois não visível

ela é errante e intercambeia

é matéria livre

mutante

pode ser ar

pode ser som

pode ser água

pode falar

pode cantar

pode aparecer

ser massa

gosma

dura

fumaça

é vela 
A presença marca principalmente um modo de estar, uma relação com o corpo, a corporeidade. Esta maneira de estar, o modo que se apresenta pode oscilar entre o totalmente denso e uma densidade próxima de zero, sendo que ao que indicam as pesquisas científicas, não existe material que não seja permeado pelo vazio. Nesse sentido, tudo seria a priori espectral. O espectral estaria justamente aí, pois nunca se refere a um estado totalmente denso. Sua tangibilidade é, assim, uma questão. Pois pode ser "tangível" como a água, ou como uma gelatina, mas se for o ar, sua tangibilidade será variável. A parafina é um caso interessante de presença espectral, pois que sua materialidade é temporal, ela se transforma, é uma matéria mutável, que varia entre o líquido e o sólido. Assim seriam todas as matérias também em mutação: como uma madeira pegando fogo, uma cera derretendo, uma água congelando/evaporando. A goma é inicialmente um pó branco, uma farinha. Quando fervida com água, torna-se em determinada temperatura uma gosma transparente para, em seguida, grudar e se tornar uma casca seca. O som, é uma presença, um corpo que pode ser sentido como mais denso ou como rarefeiro, é um corpo em potencial descontrole. 
efêmero 
MAGIA

$=$

prática de tornar presentes coisas que estão ausentes e ausentes coisas que estão presentes 
natureza

o que é natureza

tudo é natureza

o ar

a água

as árvores

os pássaros

os cantos

as bactérias

os vermes

as larvas

os elétrons as faíscas

alcançar

as paredes

o cimento

os postes

o petróleo

o plástico

a margarina

nós

os deuses

os crimes

todos 


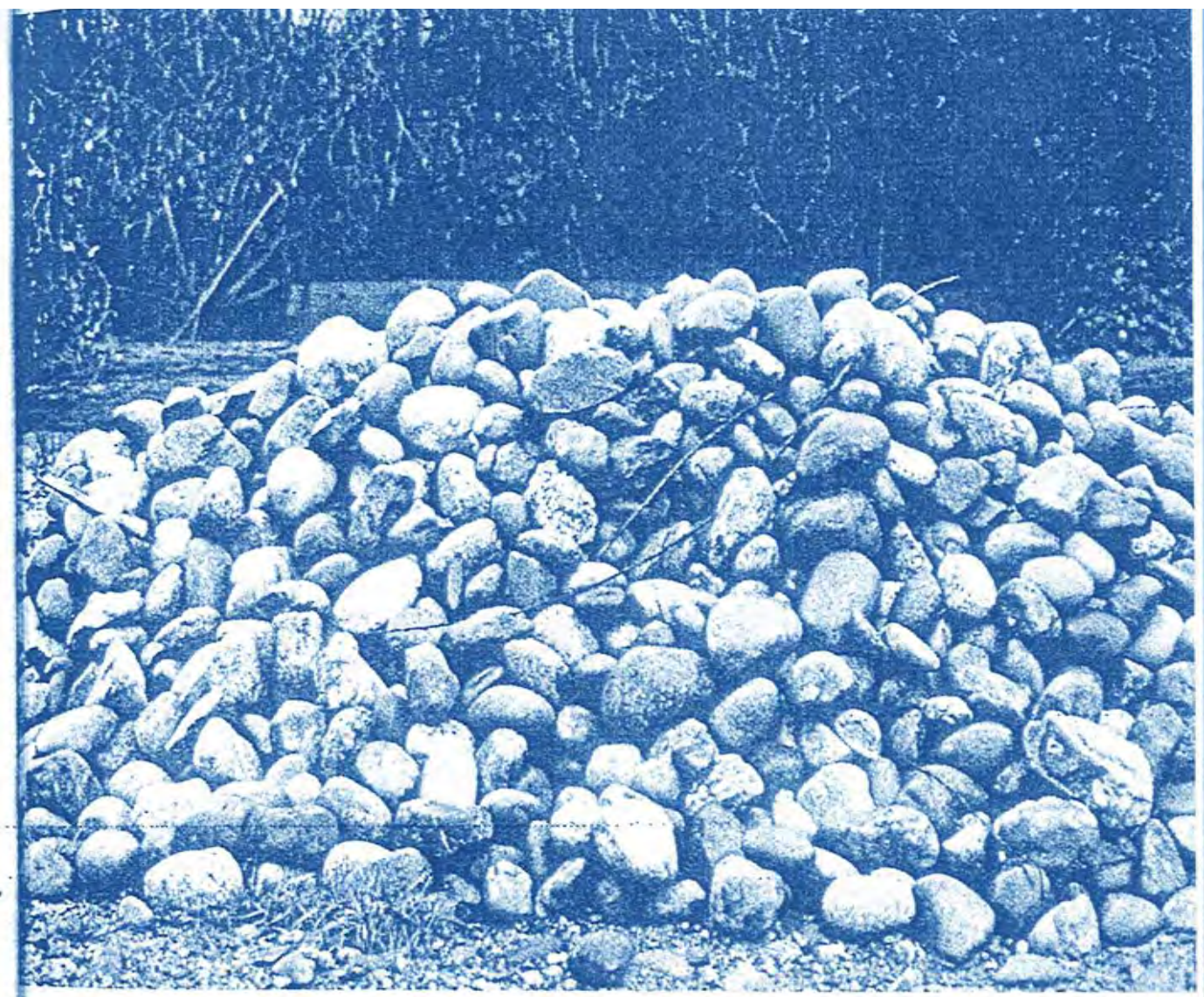




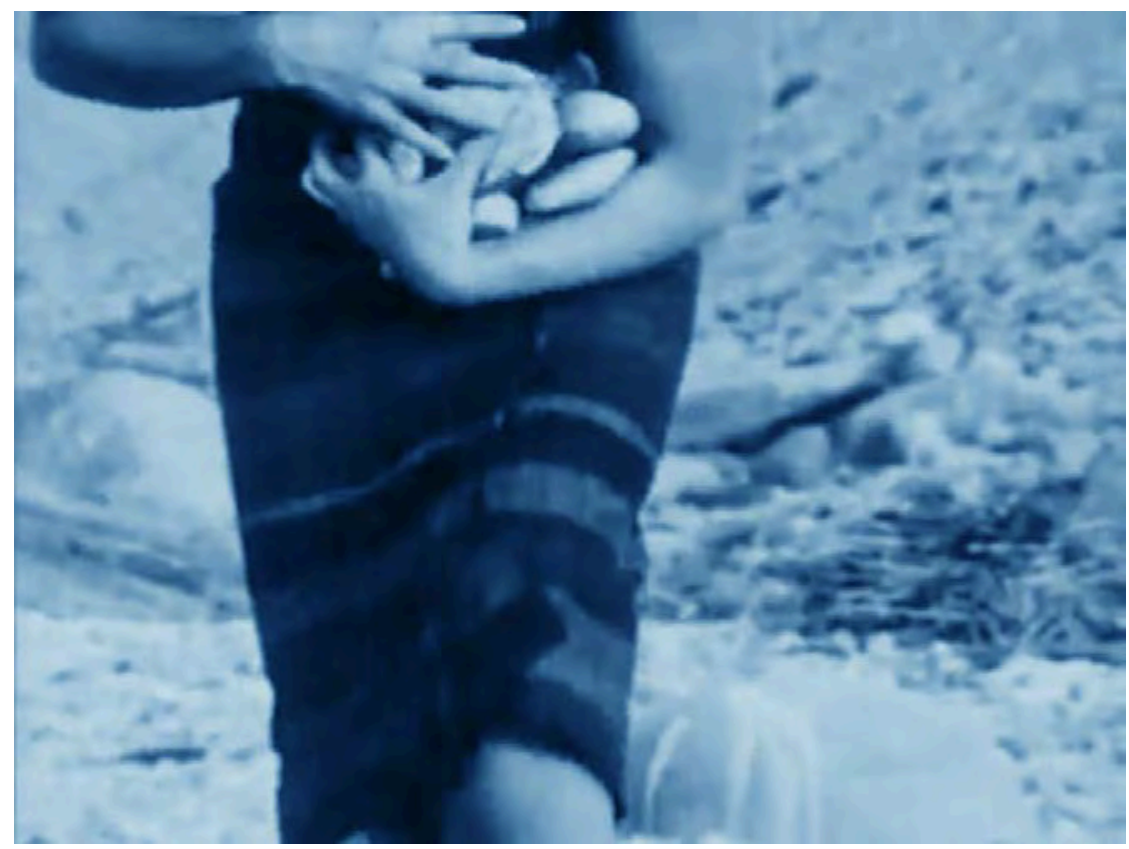




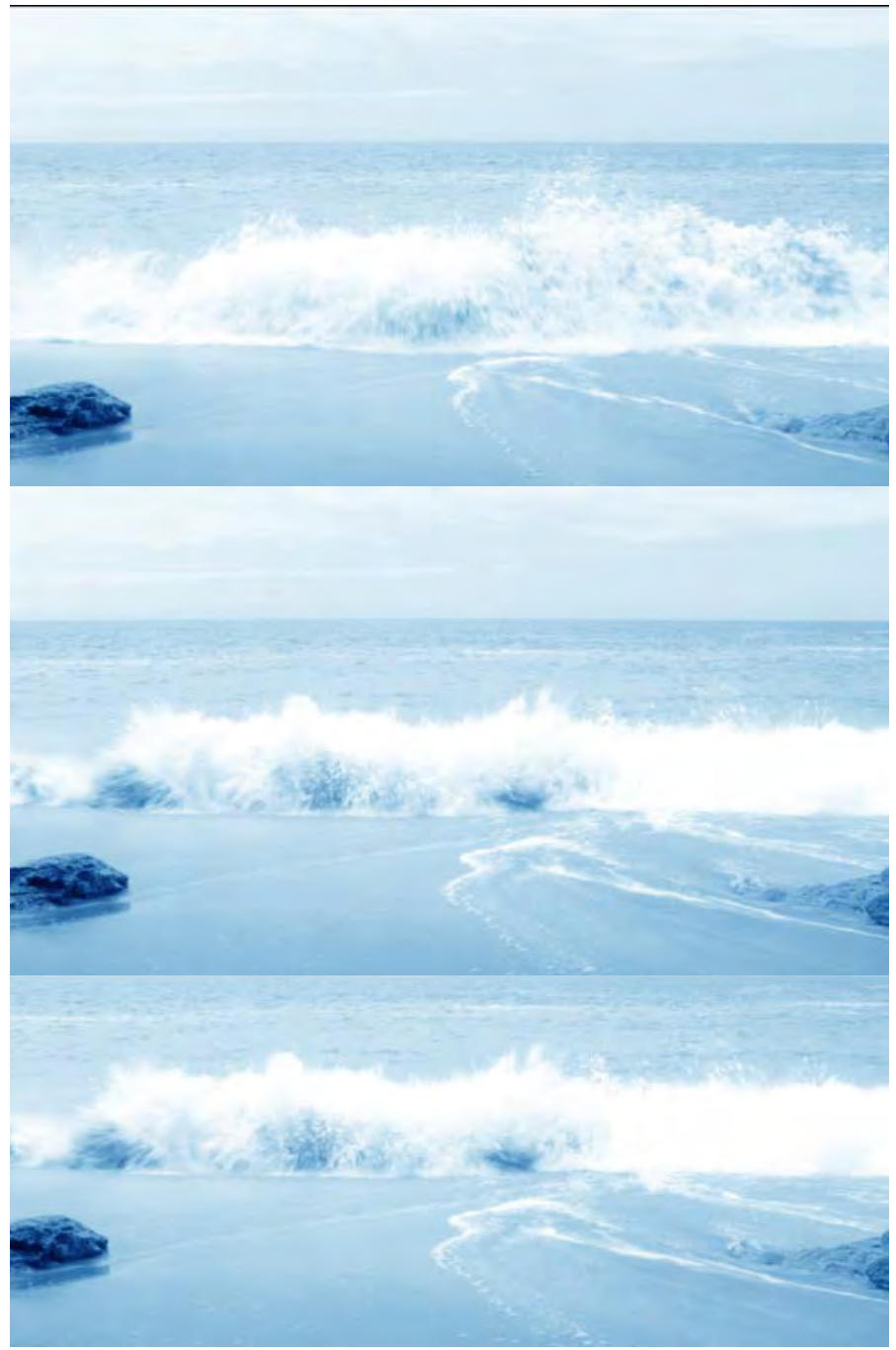




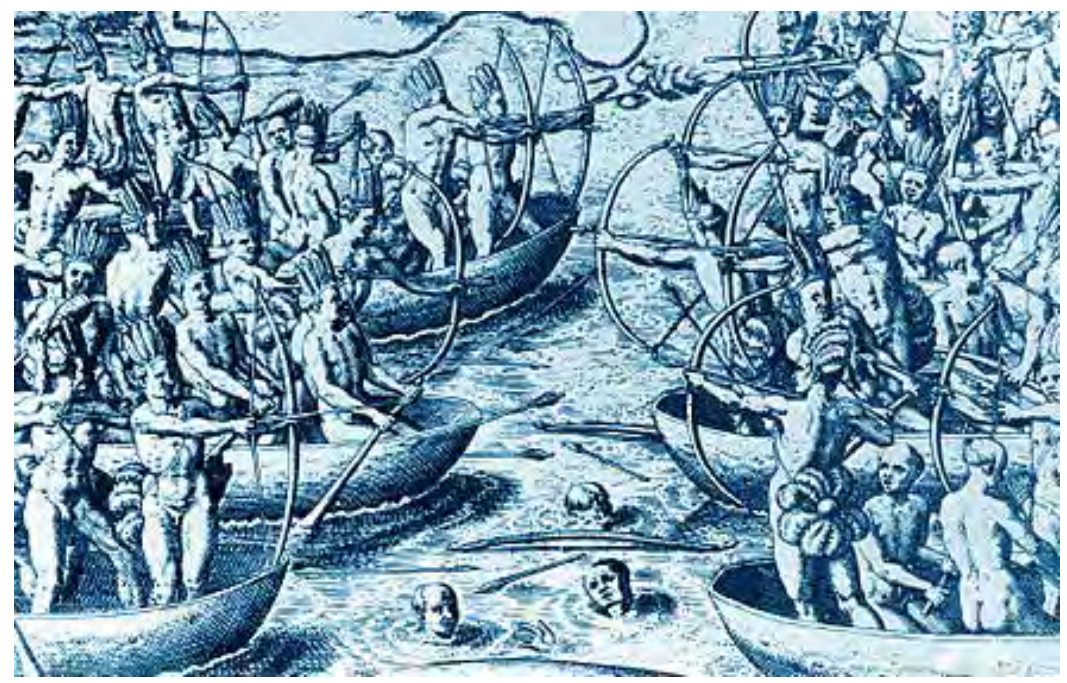


TEMPO FAZ BURACOS 


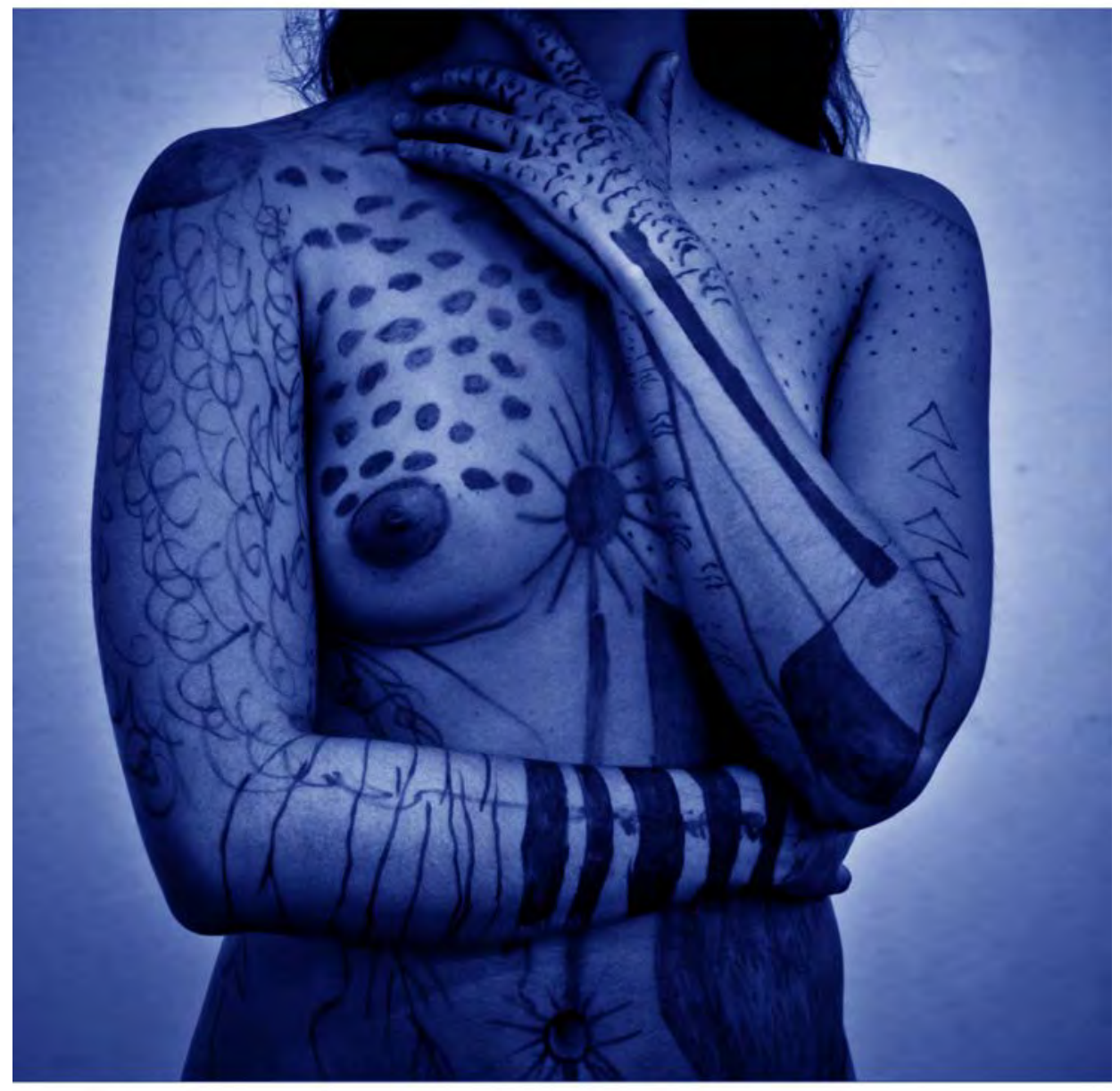




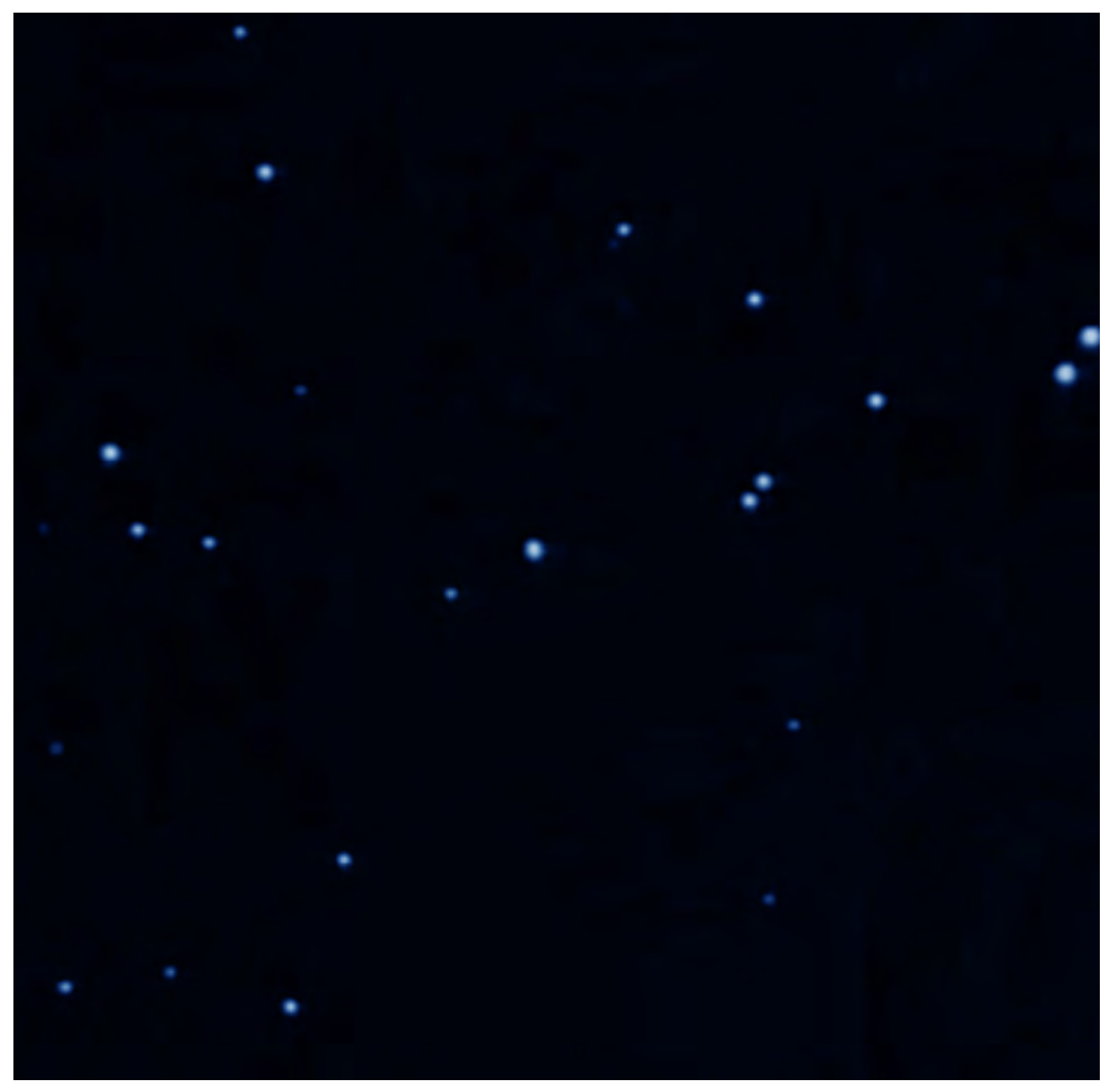




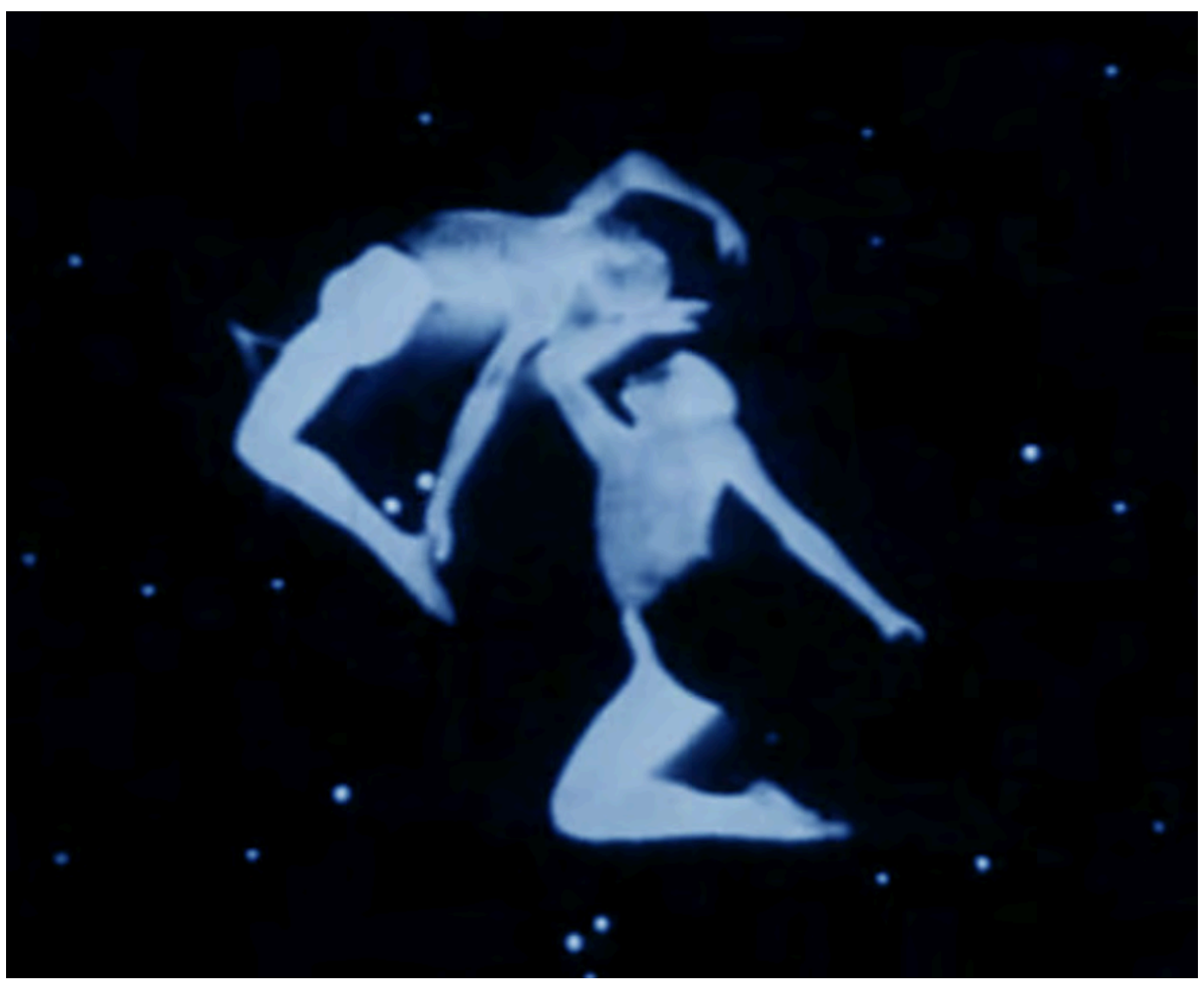


se as folhas fossem estrelas, pedras cósmicas

o que aconteceria ao agitá-las em seu meio

- o céu?

onde elas se chocariam?

onde se concentrariam?

em que tempo se dispersariam?

implosão

cacos do que já foi. 


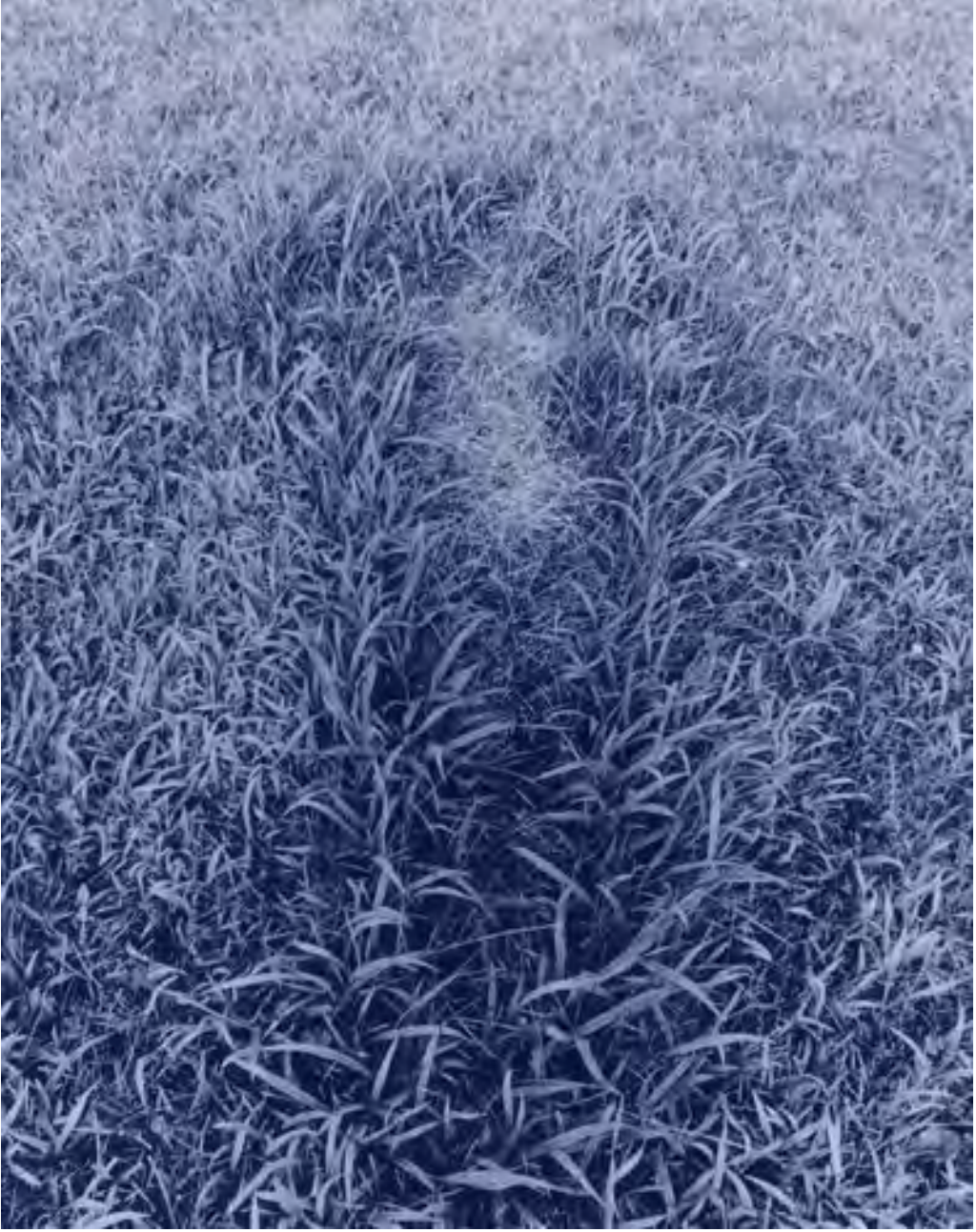




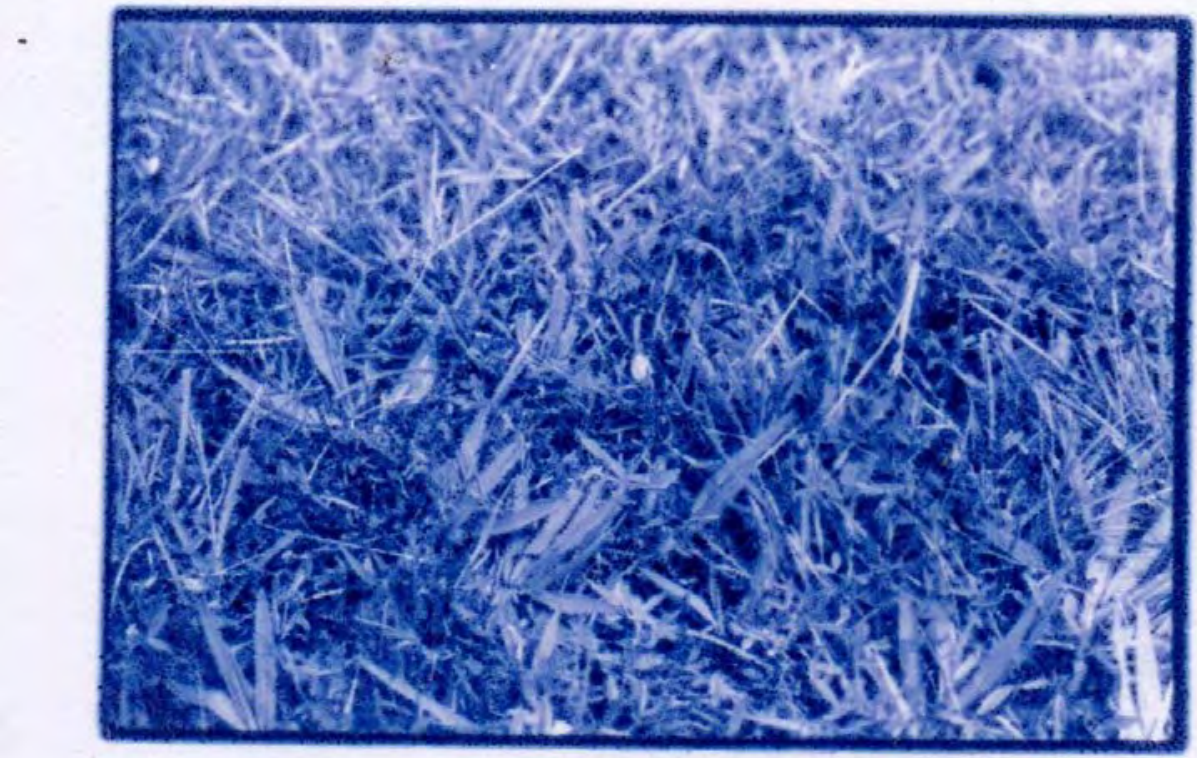

BoReoustr Gm PONTO 

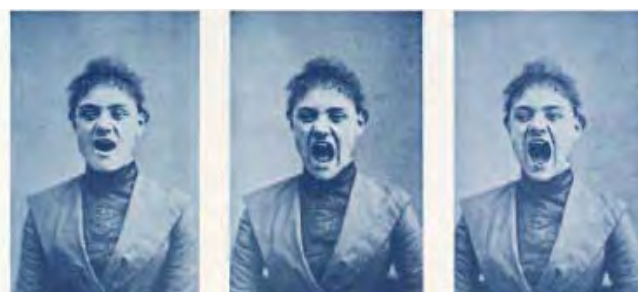


$$
\pi
$$



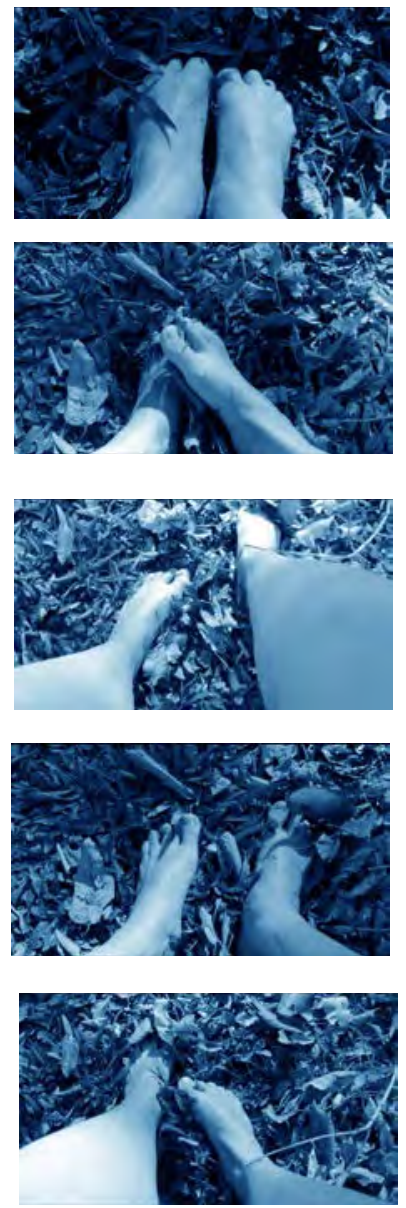



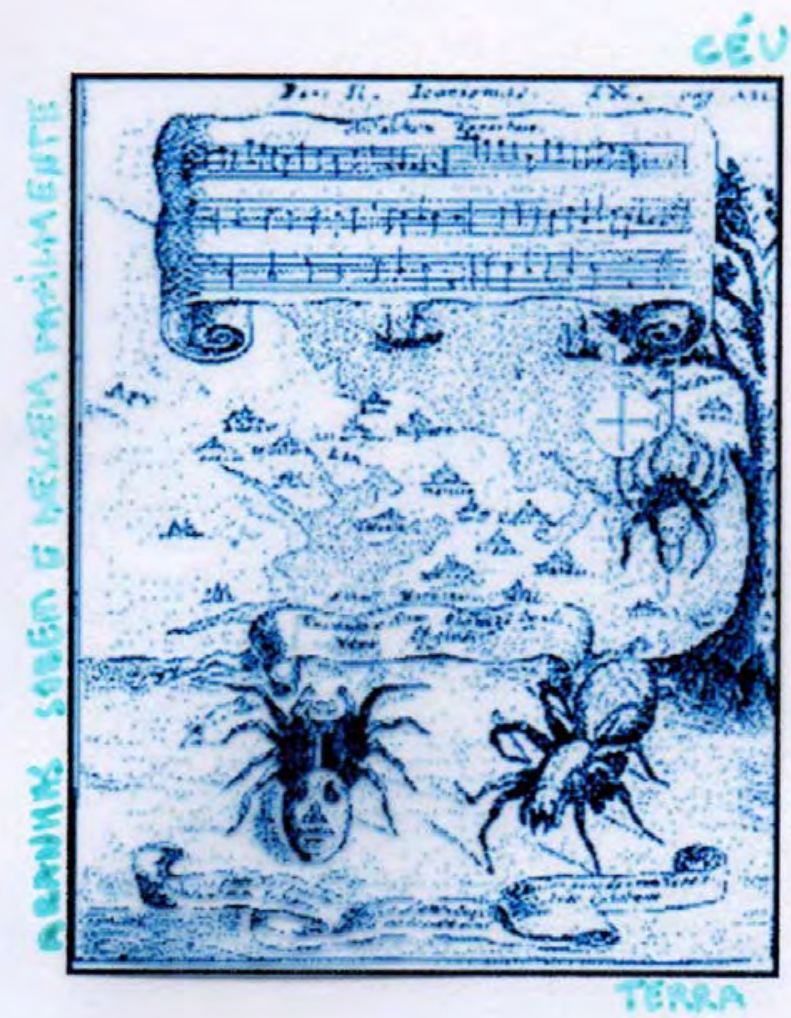




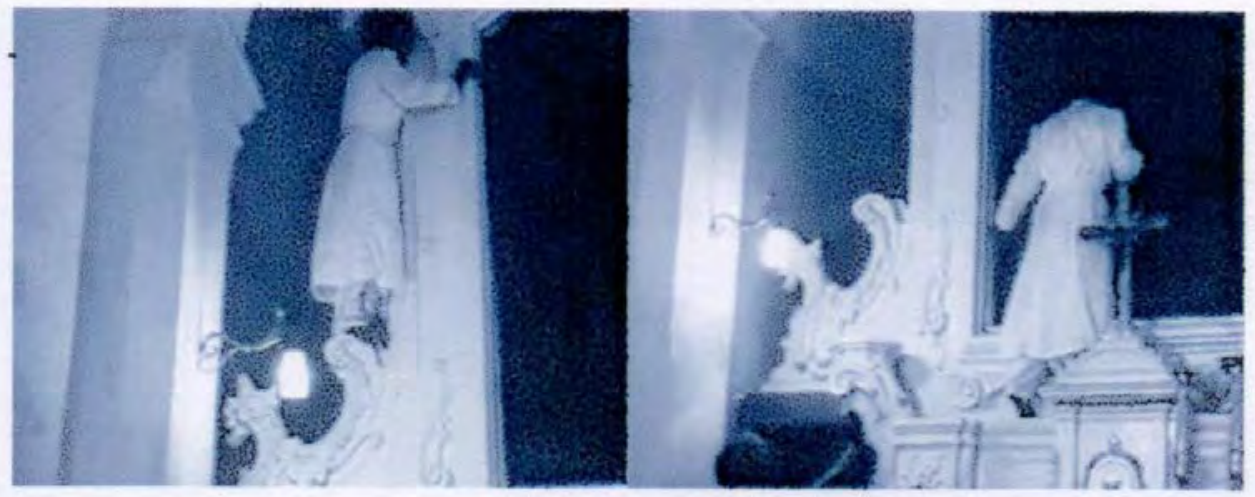

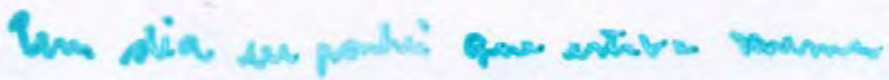

$\frac{2}{3}$

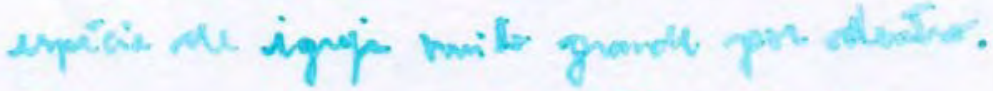

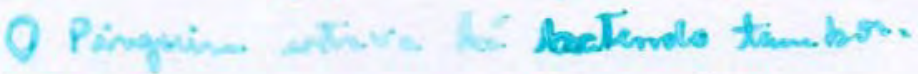

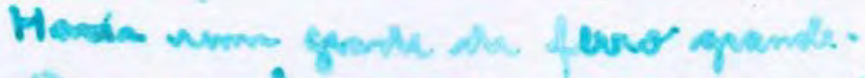

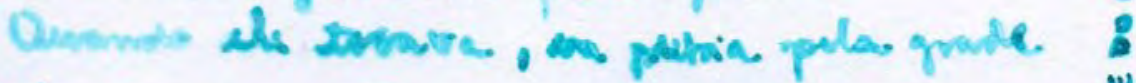

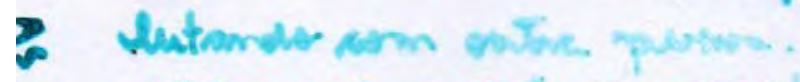

羡 

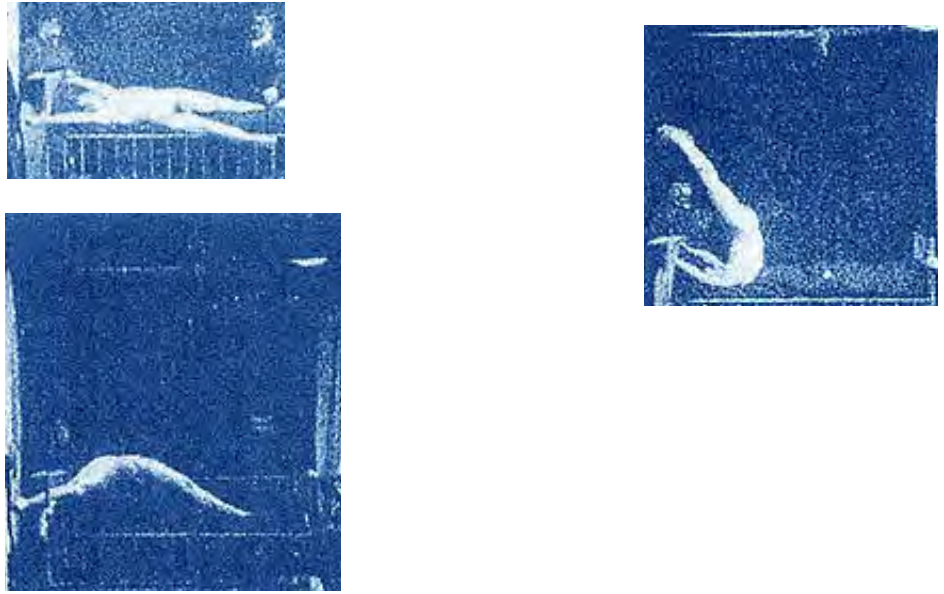


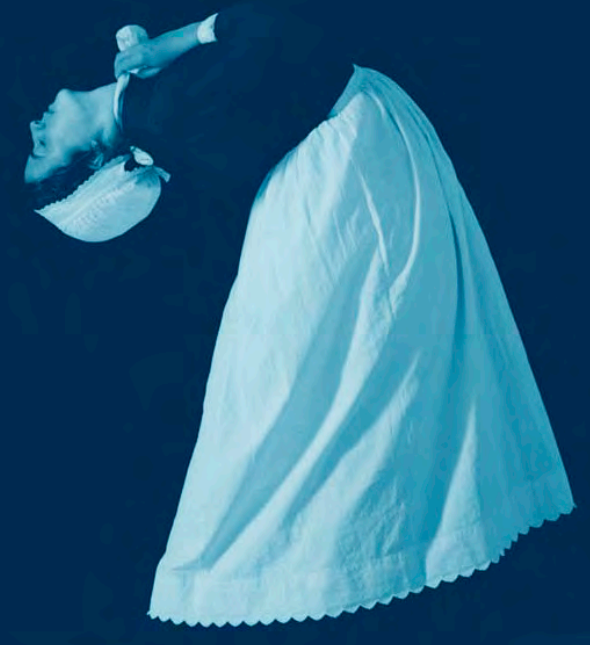




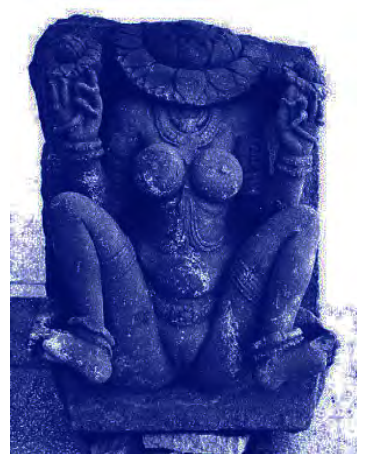




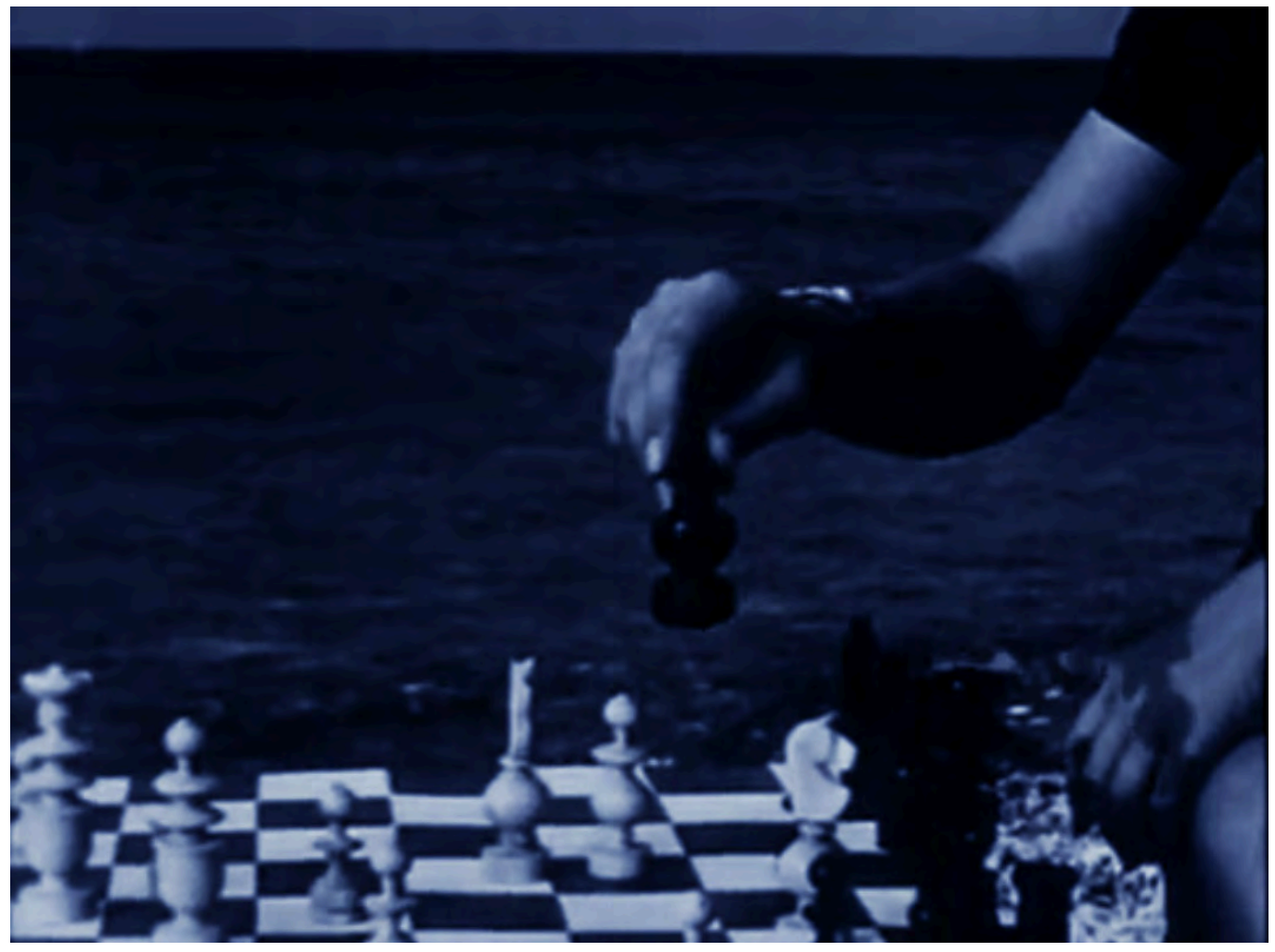




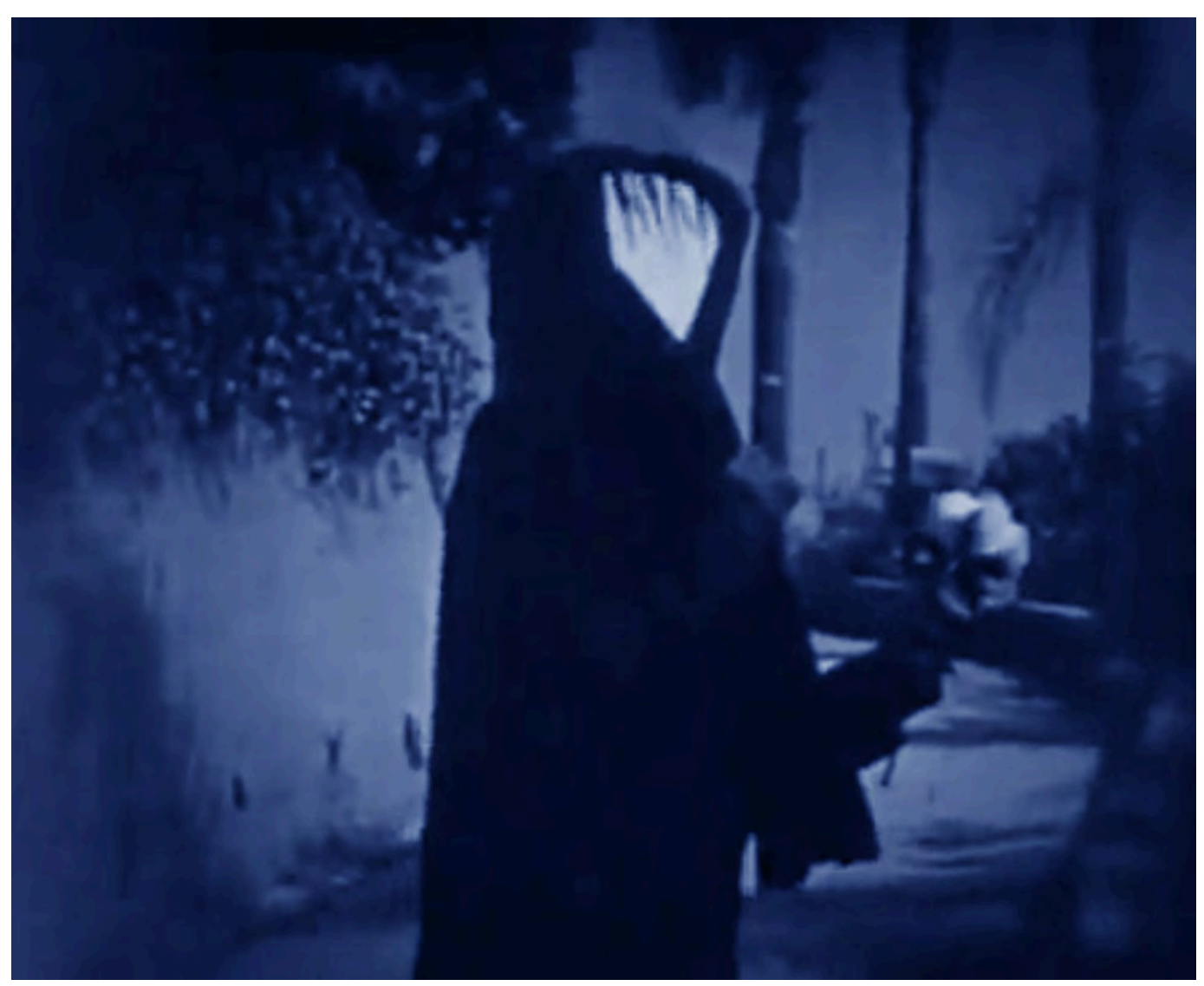



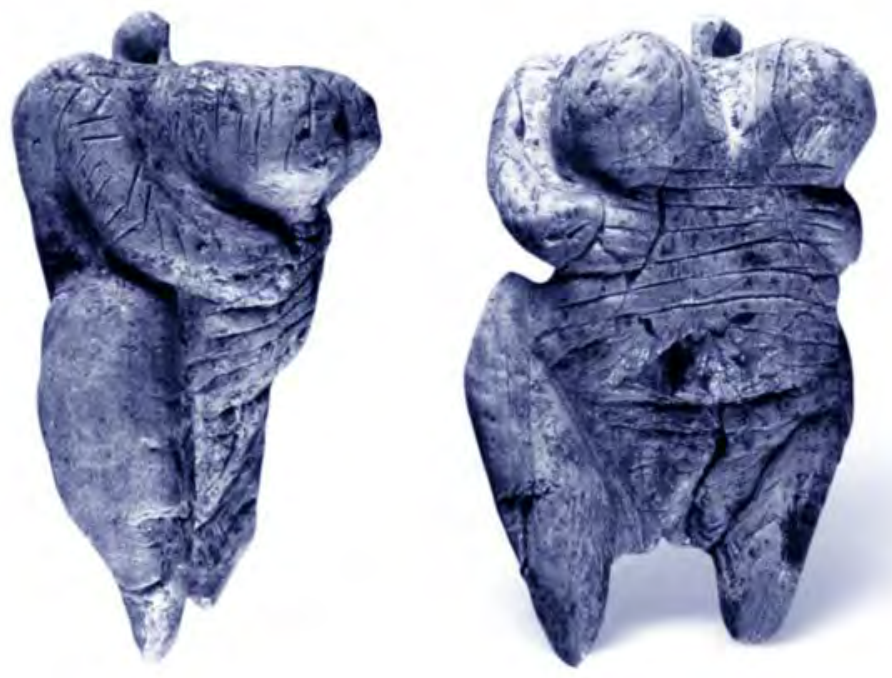


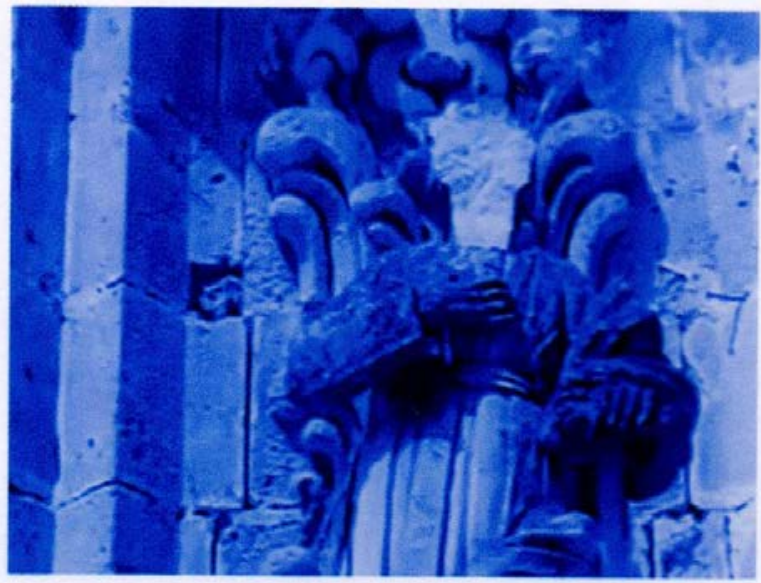

cuoes minka canega gin rompsetiab 


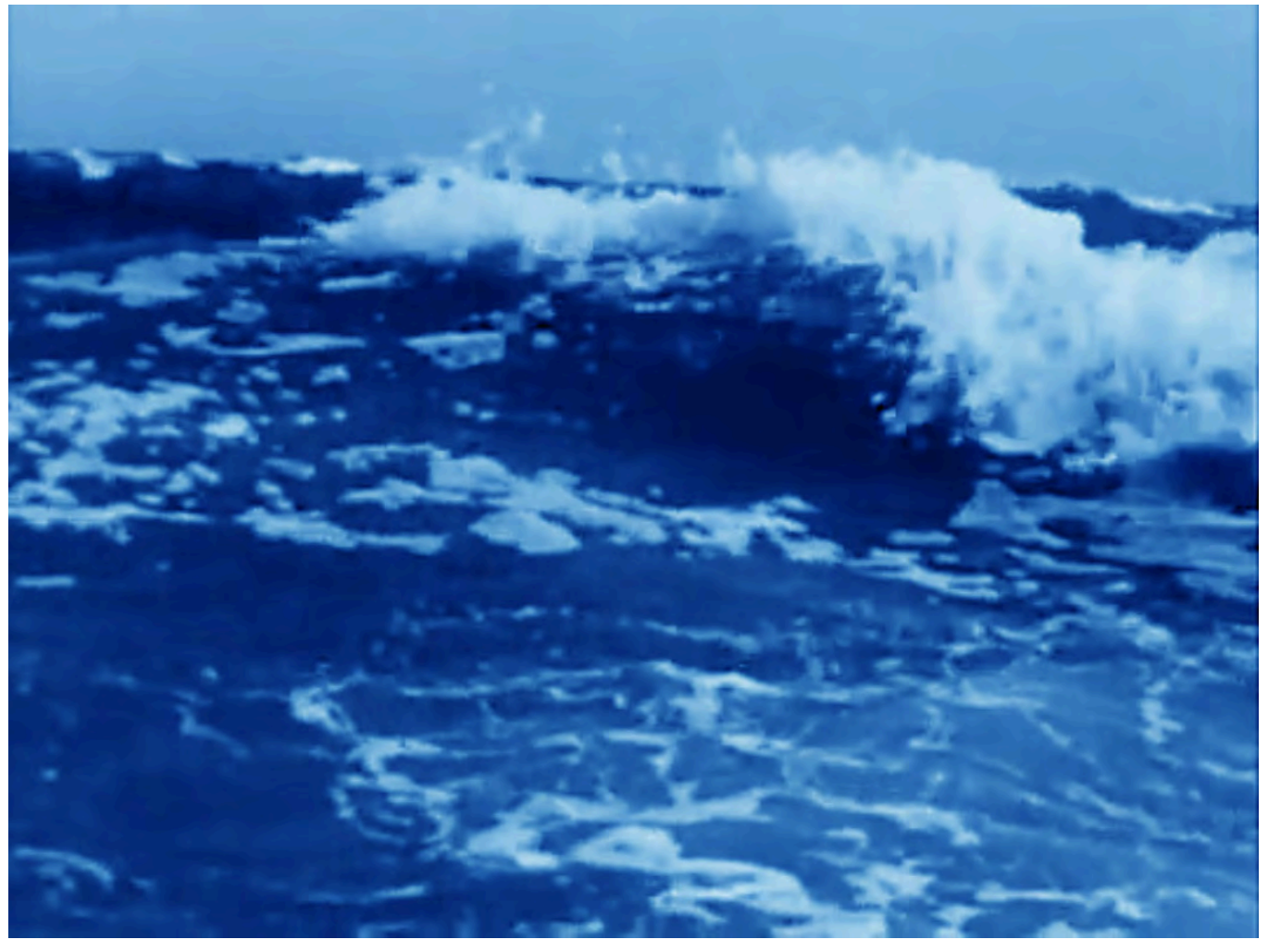





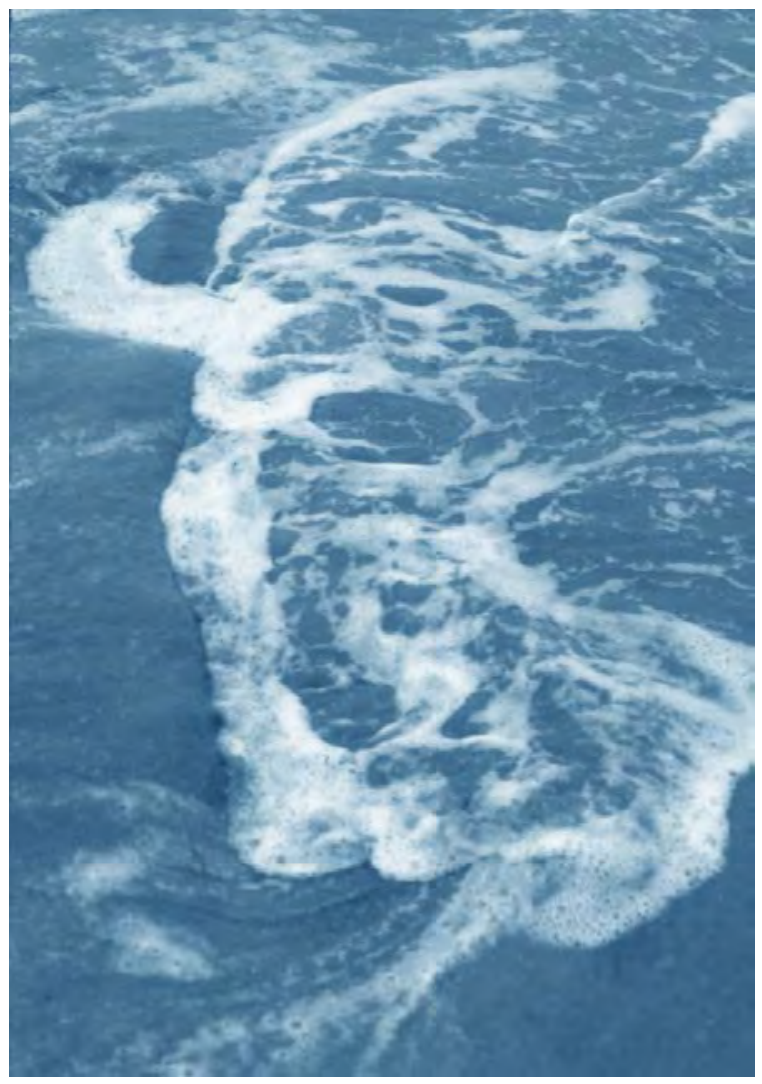



<smiles>C1CCC2(C1)CCCC2</smiles>

$$
M A R
$$





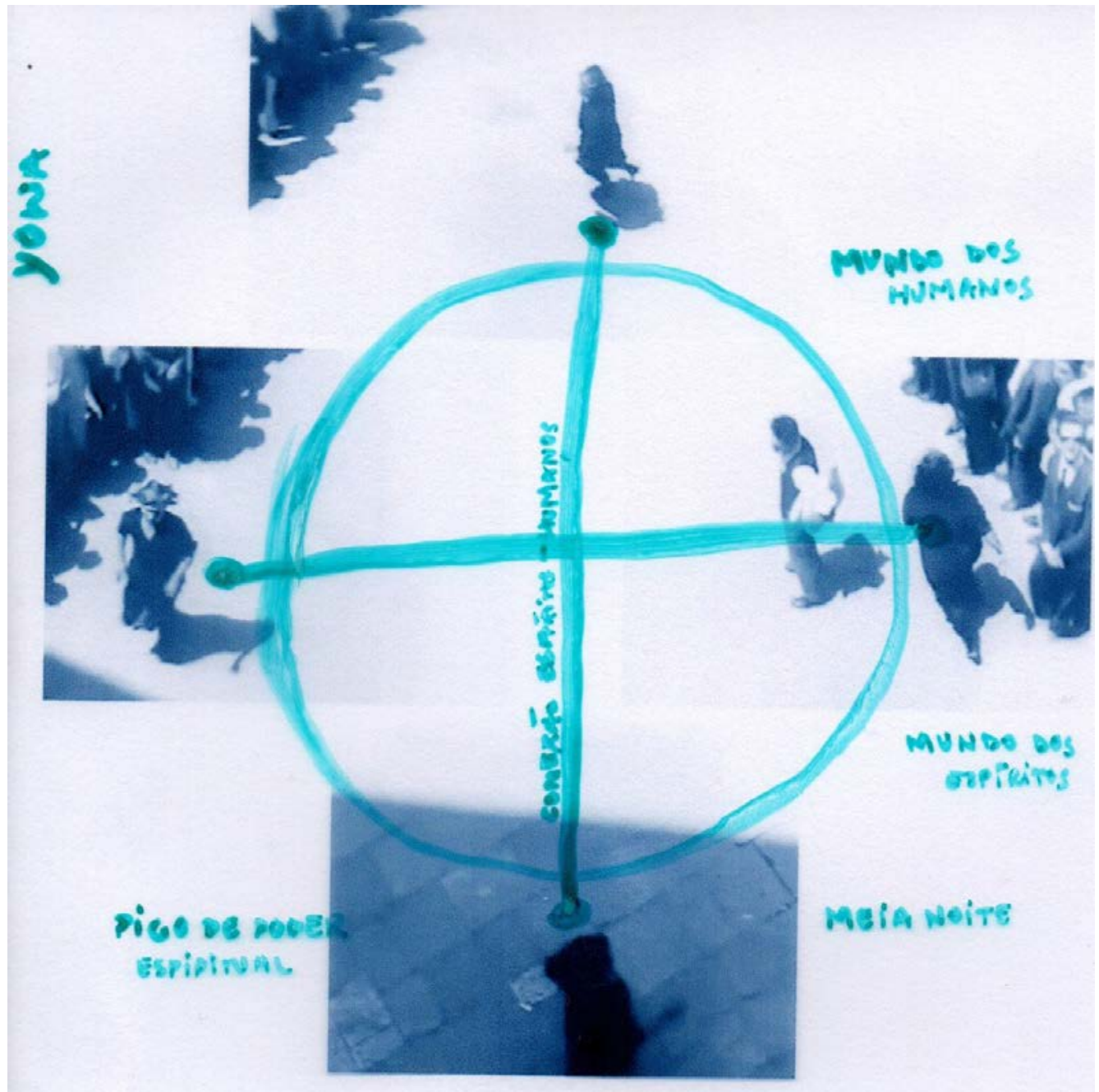


eu dancei com o mar

o mar falou sobre a falsidade

sobre a mentira

o mar não encena

tudo que mar leva, mar traz

os movimentos vem por baixo

baixo

a superfície é só um reflexo do que está por

quando você está conectado

você consegue prever os movimentos

você sente eles vindo desde baixo

e você sente a volta, a onda, as oscilações, as rupturas

antes delas acontecerem

mas você não segura, não as domina, você apenas acompanha

essa é a sabedoria do mar

mar leva em infinito

mar dança em infinito

tudo que mar leva, mar traz

a pérola é o mar condensado nas mãos de Yemanjá que é a concha

os silvos são as vozes e a fala do mar 


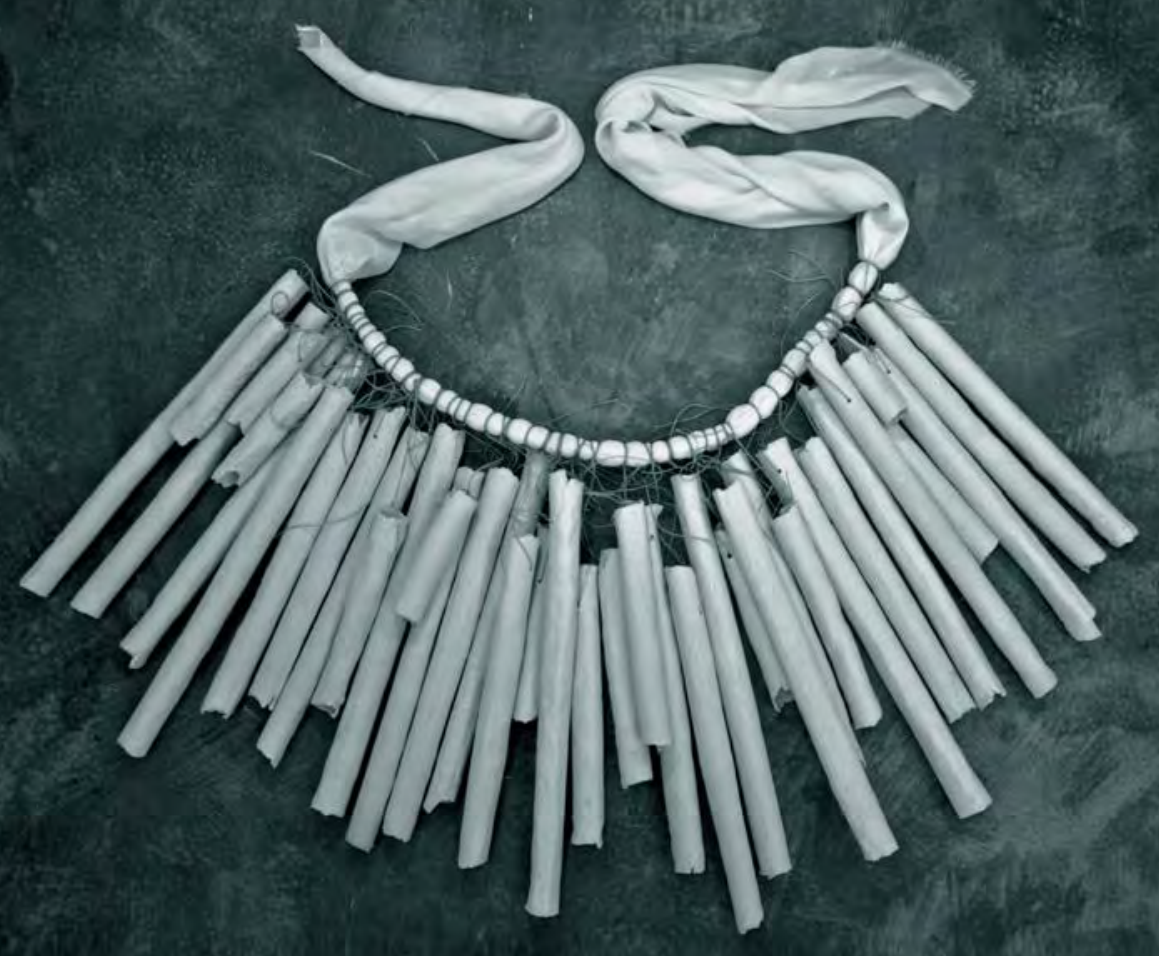


Saia Sonora / O mar não encena foi um projeto que começou anos antes com a construção da saia sonora. Ela foi construída em 2013. Uma saia de cerâmica inspirada no "mensageiro dos ventos", objeto que é pendurado em ambientes abertos ou semiabertos e que produz som com o vento. Muitos acreditam que seus sons são, na verdade, uma mensagem de espíritos e dos anjos.

A saia sonora seria assim um instrumento, um aparato performativo através do qual é possível se comunicar com outros mundos e seus seres, mas com a especificidade de que foi feita para vestir. É um aparato corporal e não um objeto que cumpre seu objetivo por si. A saia sonora foi um meio de diálogo entre eu e o mar. 
Eu havia concebido uma espécie de roteiro para a performance, na qual eu - em um local com muito vento, preferencialmente uma praia deserta - vestiria a saia e realizaria uma espécie de dança não coreografada.

Essa dança se daria a partir do silêncio corporal, do não movimento, tomando inicialmente somente a manifestação do vento através da saia para, a partir daí, iniciar movimentos que surgissem dessa manifestação, criando um diálogo corporal - a própria dança. Ao final, acreditava que a saia provavelmente se romperia, sinalizando o fim da ação. 
Quando recebi a proposta de apoio para realizar a performance chamei Guilherme Minoti, fotógrafo que me acompanha em diversas ações e com quem já estabeleci uma intimidade artística.

Decidi ir ao Guarujá. Preparamos tudo, pensando principalmente na relevância do som para o trabalho. Chegamos no Guarujá no final da tarde e saímos de carro, visitando as praias que havíamos selecionado para mapear a região e escolher em qual realizaria a performance. Encontrei muitas questões: as praias não eram desertas, havia muita gente e o espaço era muito aberto, inclusive para prédios, hotéis e restaurantes - o que fazia com que elas fossem sempre frequentadas. Não havia muita área de areia, um requisito importante. Algumas estavam bem sujas e o vento não era tão forte quanto eu imaginava.

Sentamos de noite na areia. Eu pensava em soluções ao mesmo tempo em que aproveitava a brisa e o cheiro do mar, a umidade da areia sob mim e as conversas amigas do Minoti. Imersa naquele momento... Claro! O mar também é vento! Percebi que o mar não é só água, o mar também é vento. $E$ logo percebi que não fazia sentido naquele lugar continuar o plano inicial de dançar somente com o vento. Decidimos então o recorte da câmera: de frente para o mar. 
Estávamos hospedados na casa de um conhecido de uma amiga. De noite, quando voltávamos da praia, perguntamos a ele sobre as outras praias, falamos de nossas intenções e requisitos. Ele nos contou sobre uma praia que ficava deserta pela manhã bem cedo, com muito vento e que era linda. Tínhamos poucos dias, e a previsão dos dias posteriores ao seguinte era de chuva. Decidimos arriscar. Acordamos cedo e levamos todo o equipamento, fomos decididos a realizar a ação.

Chegando na praia... realmente ela era linda.

Tudo ocorreu melhor que o previsto.

Humildemente pedi licença ao mar, dizendo que estava ali para fazer um trabalho artístico, para o mestrado, para a exposição. Disse que essa era somente minha intenção ali, que não desejava de maneira alguma brincar com a espiritualidade. E expliquei que havia feito a saia, porquê, como... enfim. Pedi licença, pedi proteção. Não há para quem mentir na espiritualidade. Fazendo todas as considerações, indo com muita humildade, com muita calma, e até com receio, comecei a me aproximar, e soube que a ação havia começado desde o primeiro pedido de licença. Porque as coisas são contínuas, não há a marcação do início como o primeiro passo programado, não há programação, não há o que programar. É inútil. Você pode apenas se preparar e estar preparado para o que tem para você. 
o que está dentro não é igual o que está fora o que está dentro diz o que está fora fora é espelho

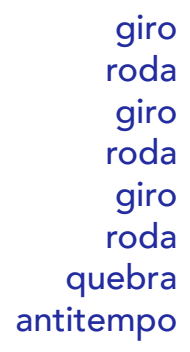


danço com o mar danço para o mar

ondas em água ondas em murmúrios ondas em vento ondas em braços ondas em giros ondas em partículas que não vejo 
balanço e convulsão 
É desnuda ela está sempre tal qual a vemos ela é sempre verdadeira se chove é porque é hora de chover se venta é vento tudo nela é verdadeiro transparente 
Eu já estava completamente absorta pelos movimentos, e pela conexão com o mar, quando Minoti me interpela insistentemente e me faz parar e responder à sua questão. Antes de parar, eu havia tentado continuar na minha imersão e acreditava que ele fosse perceber que não era possível parar, que eu não devia parar. Meu corpo estava ali, mas eu estava em outro lugar. Mas ele insistiu e interrompeu o processo que estava acontecendo.

Minoti estava preocupado com o material visual para o vídeo. Ele achava que devíamos produzir outras imagens, apontando a necessidade de uma "entrada". Para mim, a preocupação do Minoti está ligada a uma ideia de narrativa, e principalmente a uma ideia de narrativa como início, meio e fim. O que me leva a pensar sobre uma estética do acontecimento e não numa estética da narrativa.

Na minha prática artística, o início era algo que eu já não questionava. Eu não precisava de uma "entrada". Percebo essa ideia de entrada relacionada à uma concepção de palco, de apresentação, de espaço representativo, de cubo branco. Trabalho com o lugar, suas próprias características físicas e simbólicas, sua história e os costumes que o constituem - algo próximo do site especific e da instalação. 
Não era a primeira vez que isso acontecia. Eu havia desenvolvido a prática de deixar combinado tudo que antecedia a ação, para estar plenamente livre e dedicada durante a performance. Para mim, o espaço não se trata de um set de gravação. $O$ trabalho é uma performance, um acontecimento em si, em que o vídeo é um ponto tangencial e de relevância. O trabalho não está descolado da minha vida, ele é real, e não uma encenação. A preocupação estética não significa representação.

A ação tem uma estética, porque a beleza é algo importante, ela tem sua própria energia. A beleza esta em elementos específicos, organizados, no lugar e na hora certa - ainda que indeterminados - para que seja cumprida sua finalidade, ainda que esta seja incerta. Eu me lanço para descobrir, ainda que não saiba o quê. Eu me lanço. As perguntas são assim.

Existe uma medida entre controle e descontrole, entre desejo e acaso. Enquanto Minoti me questionava " mas se você quer fazer um vídeo, arte...", eu pedia inclusive para que caso eu entrasse no mar, ele fosse me buscar. Ele dizia "não, você não vai entrar no mar. Você não vai entrar". E eu continuava "esta praia é de tombo e eu não sei nadar." 
Esse evento me fez ter mais consciência do meu processo artístico. Não acho que meu amigo Minoti estava errado. Ele me fez perceber facetas importantes do meu trabalho na medida em que eu refletia sobre minhas discordâncias a respeito de suas colocações, na necessidade de justificá-las e explicitá-las a ele durante as tomadas de decisões na realização do trabalho.

Eu já havia percebido a grande necessidade de improvisação na captura de imagens. De modo que, desde o princípio, sabia que utilizaria duas câmeras na captura da performance, uma fixa e outra livre nas mãos do Minoti para que ele pudesse improvisar e produzir imagens que partissem dos movimentos e do espaço. 
Uma estética do acontecimento gira em torno do acontecimento em si. É um zoom que mora num recorte de tempo, efêmero e que não depende de uma sequência linear (início, meio e fim), mas carrega elementos que tem um passado, uma história, um repertório. Assim, ela reside numa suspensão do tempo e do espaço - lugar de indeterminação, ambiguidade, perda, desorientação - cujo colapso se dá pela certeza do acontecimento somente pela presença, ainda que efêmera, e pelo seu pertencimento a um continuum da existência no universo. 
Na estética do não acontecimento há uma concentração em poucos elementos. Não se conta uma história. Não há acontecimentos. Há uma variação muito sutil num longo tempo. Dilatação do tempo.

Alguém pode se perguntar o que esta acontecendo. Pois aparentemente nada acontece. O que sucede é uma imersão no não acontecimento - nas sutilezas, na variação, nos movimentos. Os sentidos ficam mais aguçados, a percepção mais atenta. Ativa-se outros níveis de percepção.

$O$ vento passa a cantar e a luz a tocar.

Não há narrativa, não há palavras.

Tempo de estar. 


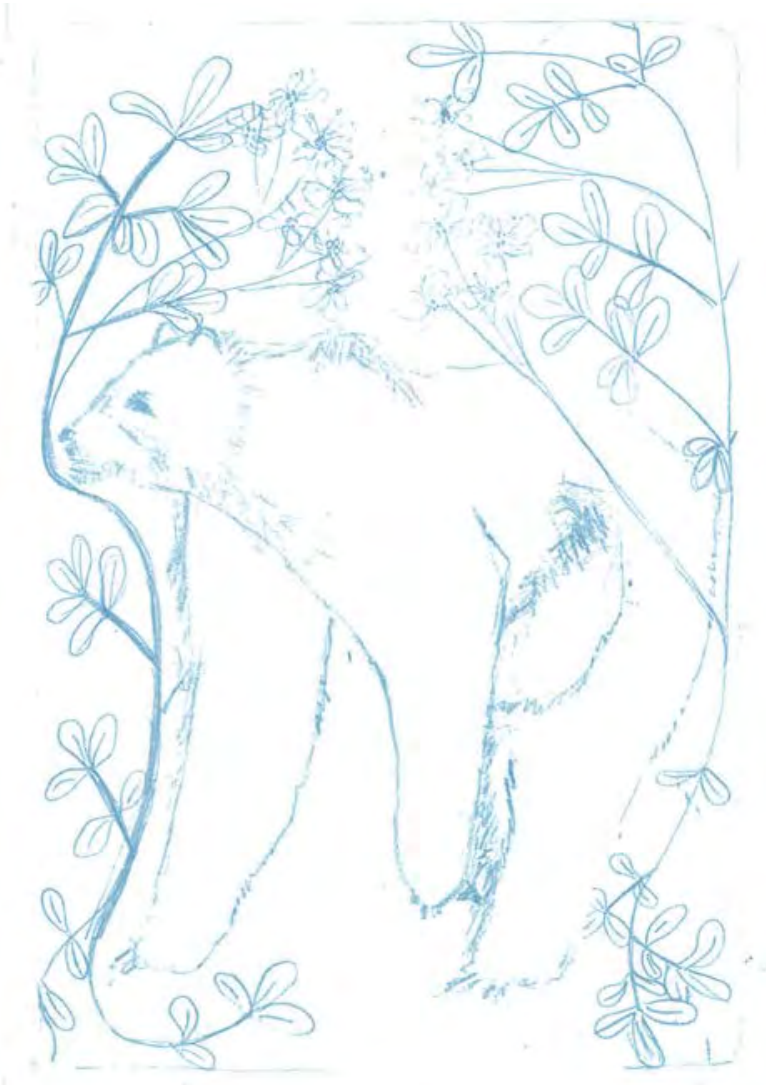




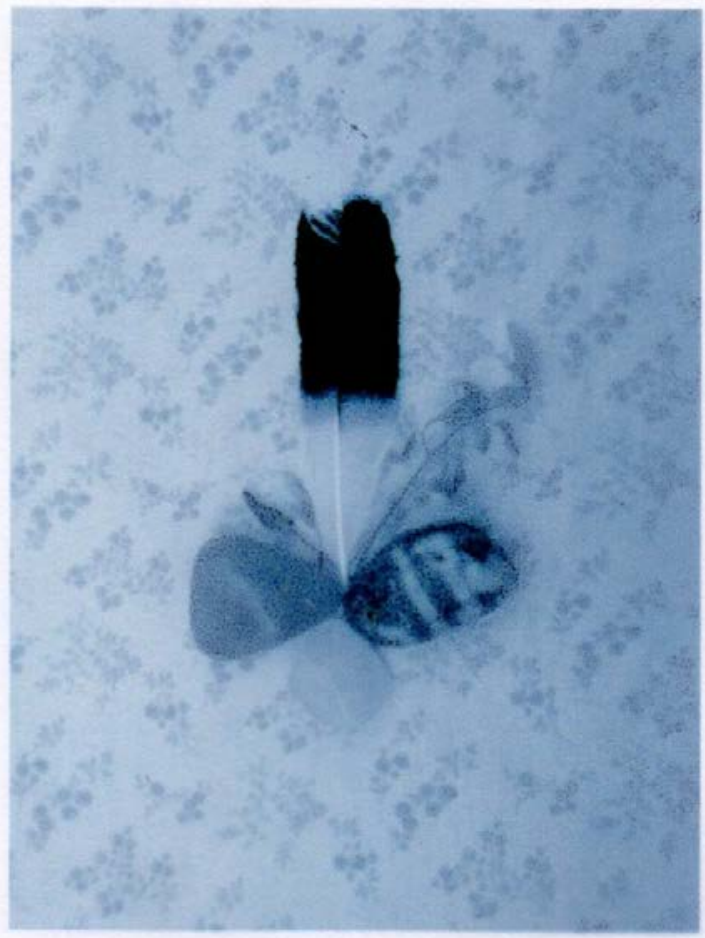

GAMPE STERsirstast 


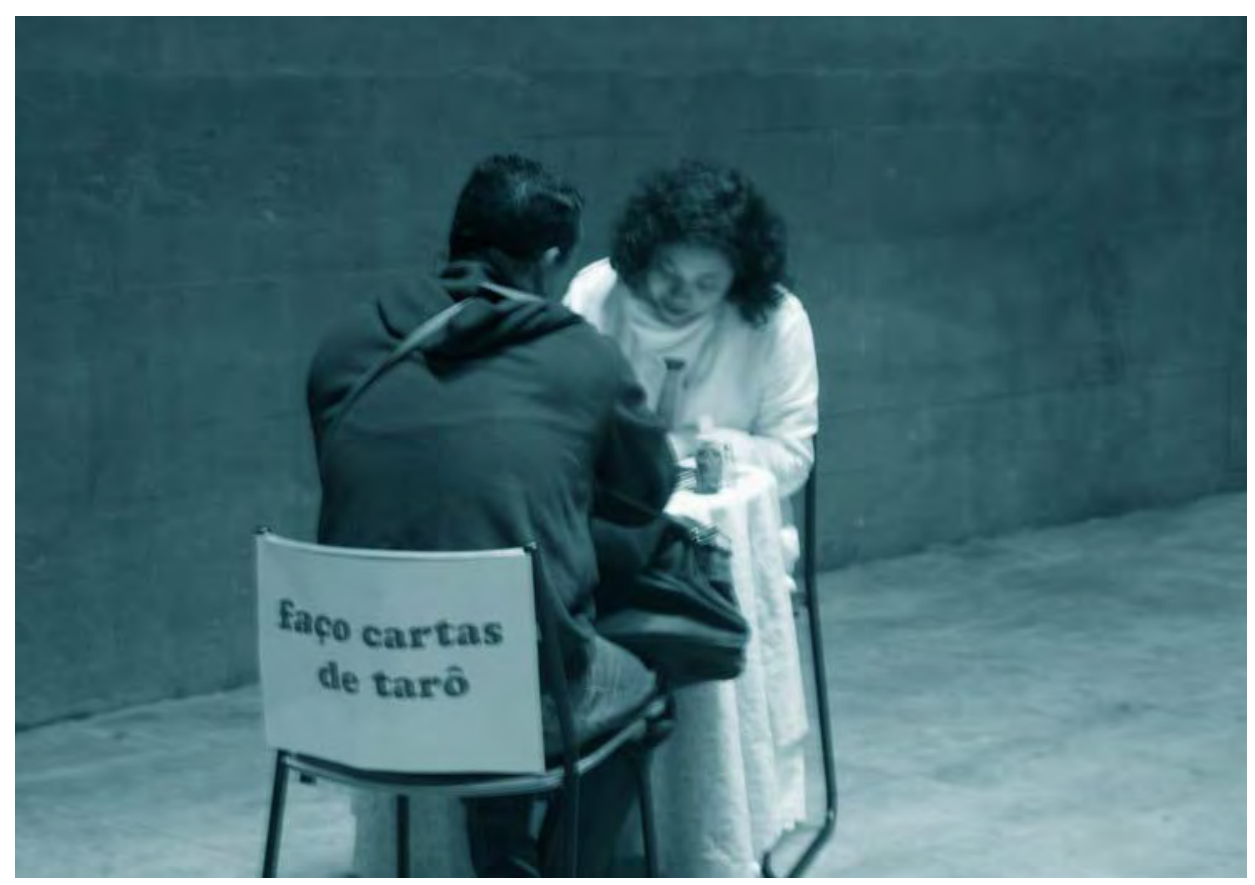

"A artista estará sentada em uma mesa aguardando àqueles que se sintam convidados a receber uma carta de tarô que será desenhada durante uma conversa. Cada carta será criada especialmente para cada pessoa." 


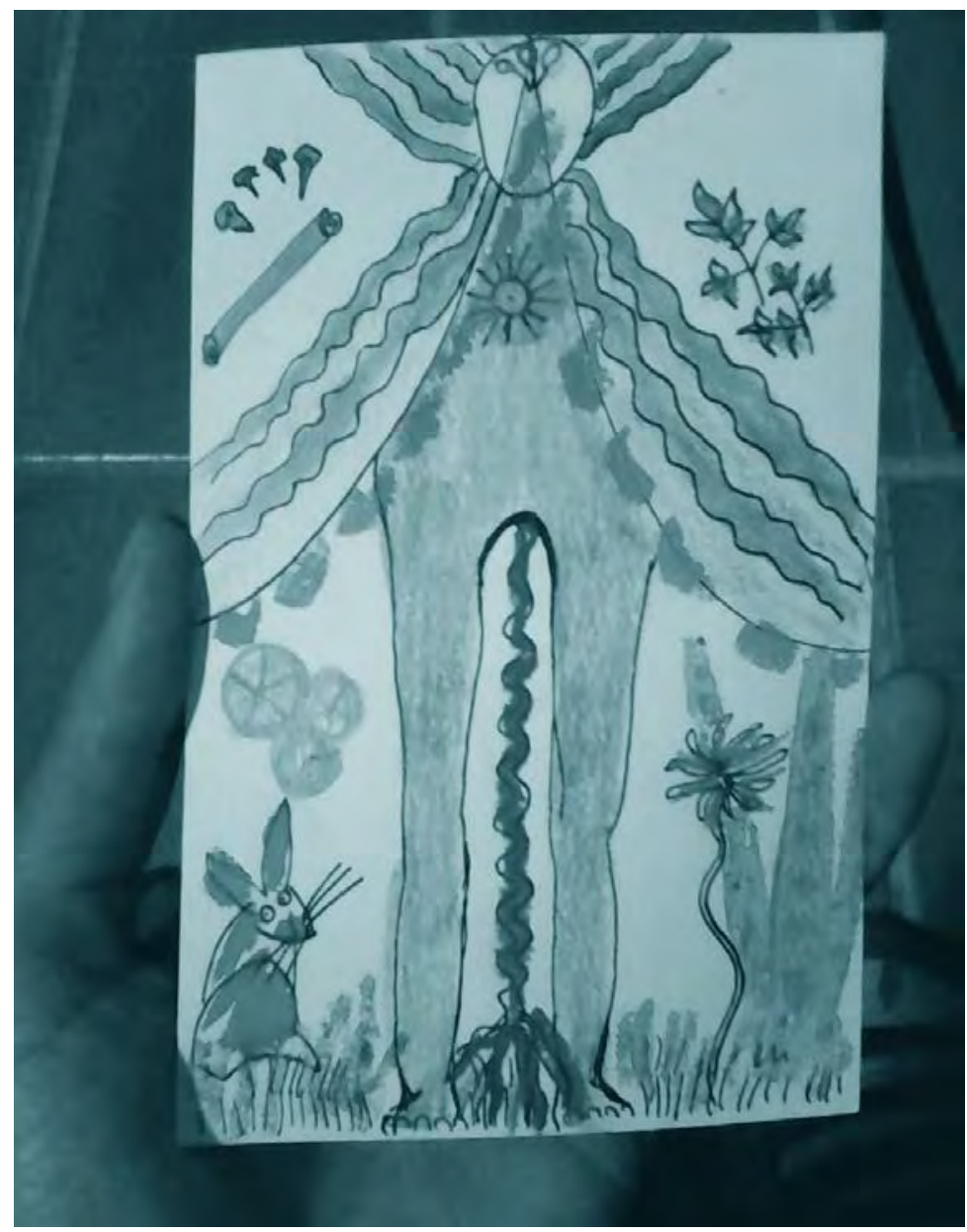


Eu, que sou artista e terapeuta holística, encontrei-me um dia me perguntando durante os atendimentos: por que as pessoas não sabem disso? Por que elas não sabem lidar com suas emoções? Por que elas não sabem como funcionam seus corpos, quais são seus órgãos frágeis e fortes? Por que elas não sabem identificar o que elas tem? Por que não sabem fazer um chá ou um banho?

Seriam esses conhecimentos de acesso restrito assim como por vezes parece acontecer com as artes?

Que sentido faz isso?

São conhecimentos importantes.

Porque elas não sabem disso? Porque elas não aprenderam isso?

Elas deveriam ter aprendido isso na escola?

O que é importante sabermos? O que é importante aprendermos na escola?

Vi-me então diante de desafios. Eu me lancei.

Queria testar esse conhecimento restrito. Ele interessa às pessoas?

Qual a potência desse trabalho no universo das artes?

Meu trabalho artístico tem sentido em espaços públicos urbanos? Quais sentidos?

Quais as possibilidades de encontro entre espiritualidade, espaço público, artes e o centro de São Paulo? 
Recebi um convite para realizar uma performance no evento Presença Permeável que acontecia às quartas feiras na Praça das Artes, que está localizada no Vale do Anhagabaú, no centro da cidade de São Paulo.

A Praça das Artes é um espaço cultural público. Sua arquitetura aberta e localização central favorecem a visita de frequentadores diversos: moradores de rua, ambulantes, artistas, professores, estudantes, crianças e público geral.

Aceitei a proposta, pois realizar esta performance num espaço como a Praça das Artes, foi uma oportunidade de enfrentar um desafio que há algum tempo me propunha e questionava. O diálogo dos trabalhos artísticos que realizo com a natureza é fundante. Muitos acabam por serem realizados em isolamento, seja pela necessidade de concentração e imersão, seja pela escoIha dos lugares, que muitas vezes são mais apartados. $O$ trabalho se dá na esfera da intimidade, indo em sentido contrário ao do espetáculo. No entanto, eu me perguntava como seria realizar meu trabalho num espaço público e urbano; se isso era possível; se fazia sentido. 
A proposta da performance era criar um lugar, um tempo e um espaço para testar a aproximação entre a operação artística e a curativa (feitiçaria) num espaço público e urbano. Um campo diferente do que estava acostumada a realizar trabalhos - comumente espaços isolados, abertos, "naturais", como cachoeira, mato, praia.

A performance tinha a intenção de, no campo da arte, operar a criação de cartas de tarô, ou seja, portas de comunicação que carregassem cura, ao colocar cada pessoa em contato com seu veneno para que a cura pudesse ocorrer. Mas as cartas não seriam reproduções nem releituras de cartas de tarô como as já conhecidas. As cartas seriam únicas, criadas de modo personalizado para cada pessoa que desejasse participar.

Assim, não havia como saber o que iria acontecer, que desenho eu faria, pois tudo dependia de quem sentasse alí à minha frente. 
Através

das cartas, dos

desenhos, crio:

ponho em

contato

com o

veneno

que

cura. 


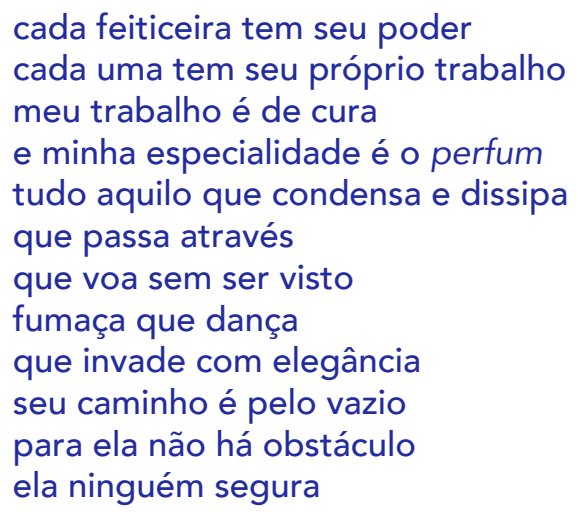

volátil

escapa 
Artista Feiticeira

operação entre o mundo das ideias e da matéria.

que faz arte e feitiço num tempo só

une as duas coisas

mulher

une arte e poder

damas da noite que guardam antes do galo cantar elas sabem ver no escuro o que você não vê nem no luar

feitiço

não faz bem, não faz mal

quem chega cantando de mancinho

quem olha vê graça e inocência

mas quem sabe não vê 
Como eu estaria num espaço cultural, - um espaço que não é destinado a lidar com trabalhos como o tarô e, por isso, não muito apropriado para este tipo de trabalho pensei que seria importante de alguma maneira, transportar a força do meu trabalho de cura para a performance. Pensei que o verso da carta seria um bom lugar para isso, uma vez que ela seria literalmente a base dos desenhos realizados.

Num primeiro momento desenhei uma carta com um urso e arruda com florescência, buscando condensar em poucos elementos a força do trabalho. Mas mudei de ideia.

Preocupei-me em não utilizar símbolos rebuscados, ou imagens que pudessem suscitar qualquer desconfiança ou hesitação nas pessoas. Escolhi assim compor uma imagem aparentemente ingênua, mas que presentificasse o que se fazia necessário, de modo também a ser uma maneira de identificação de quem o fez.

A presentificação se fez através da fotografia de um arranjo de elementos materiais que de fato pertencem ao meu trabalho de cura enquanto terapeuta holística. $\mathrm{O}$ outro lado da carta estaria em branco, sobre o qual realizaria o desenho. 
Na realização da performance havia uma mesa redonda e duas cadeiras, uma para mim e outra para as pessoas que desejassem participar.

Sobre a mesa estavam minha toalha de trabalho, lápis de cor, giz pastel, um perfume para mim e um perfume spray para limpeza para utilizar caso fosse necessário, pois estava num lugar aberto, desprotegido, com muitas pessoas. Eu estava toda de branco, vestia calça, tênis, blusa, jaqueta e cachecol. O branco era para facilitar a performance em nível espiritual e energético.

Todos os elementos serviam para a realização da performance em diferentes instâncias, tanto para o desenho em si, quanto para a minha proteção e do local onde a ação acontecia, de modo a viabilizar a efetivação da performance.

Era uma quarta feira à tarde. Havia chovido muito. Fazia frio. Eu nem sabia se realmente apareceria alguém, ou se alguém se interessaria em participar. 
Simplifiquei ao máximo esse ritual. Em momentos como este, a mente e o coração são muito importantes, pois eles comandam o que vai acontecer. Eram eles que já haviam determinado que todo aquele que ali se sentasse havia me autorizado para ver e para falar o que eu via. Assim, dispensei grande parte do ritual que envolve o tarô, mas sabia que eles estavam ali embutidos. Eu havia apenas literalmente transformado eles. E são os comandos da mente e do coração que faziam daquilo tudo verdade. E por isso funcionavam e se materializavam. 
Comecei organizando a mesa e, em seguida, anexei nas costas da cadeira que ficava à minha frente e na direção da rua a placa "Faço cartas de Tarô".

Comecei atendendo a primeira pessoa sem me preocupar com o tempo de duração da conversa, pois só havia ela inicialmente. Perto do final da conversa - até então eu estava entretida e concentrada em nossa conversa - eu olhei para o entorno e vi que num dos bancos que se encontrava relativamente próximo da minha mesa se enfileiravam sentados, um ao lado do outro, pessoas que olhavam em minha direção. Já havia se formado uma fila.

A pergunta que sempre aparecia era "você lê tarô?"

E a resposta que seguia era "eu faço cartas de tarô". Fazia isso com muita atenção, compreensão e paciência, pois percebia que era essa a primeira dubiedade que atraía as pessoas. E percebia como esse universo era de grande interesse geral. E por um instante me perguntava se elas não haviam percebido que eu estava num espaço cultural e que uma cartomante provavelmente não estaria ali oferecendo aquele tipo de trabalho. Mas então percebi que, não por um acaso, eu também havia escolhido aquele espaço para fazer essa performance. A proximidade física com a rua e a proximidade simbólica de seu funcionamento, cheio de ambulantes e oferecimento dos tipos mais variados de serviços (inclusive não autorizados), fazia de mim mais uma entre todos.

A segunda pergunta que seguia era "quanto custa?"

E respondia que não custava nada. Perguntava receptiva "você viu a placa? Eu faço cartas de tarô. Esse trabalho, faz parte de uma programação da Praça das Artes, que convida artistas pra virem fazer seus trabalhos. E hoje eu estou aqui, fazendo esse trabalho." 
Sempre que essas perguntas apareciam eu me preocupava em explicar que se tratava de um trabalho artístico. Mas isso não acontecia como um problema, como uma tentativa de reverter um engano. Mas, primeiramente, como respeito, acreditando que as pessoas devem saber do que se trata, para então decidirem se querem participar, ou não. Segundo, porque isso fazia parte da performance - e eu percebi isso conforme ela acontecia.

De fato se tratava de uma performance, de fato eu estava ali para fazer cartas e não para ler tarô. Não havia um jogo de tarô na mesa. Eu mostrava as cartas em branco para a pessoa, e explicava que se ela quisesse, ela sentaria ali e eu faria uma carta para ela durante uma conversa, utilizando giz e lápis de cor.

Nenhuma delas vacilou. A oportunidade parecia ser para elas imperdível.

Apenas algumas desistiram devido à espera, pois se juntaram muitas pessoas na fila no banco. Uma delas, uma moradora de rua, parecia alterada, muito impaciente, ia e voltava muitas vezes, e ao final desistiu. 
A primeira pessoa que participou da performance era uma senhora. Pareceu um pouco desconfiada, mas logo revelou alguns conhecimentos. Enquanto conversávamos, ela expunha as questões de sua vida que desejava falar. Eu sempre dizia que a pessoa podia falar o que desejava, a questão que desejasse falar, ou o que a trazia ali.

Enquanto conversávamos, em determinado momento, indefinido e variável, eu começava a desenhar. E a conversa prosseguia enquanto eu desenhava. Ao final, eu mostrava a carta para a pessoa, perguntava o que ela achava da carta e então explicava o que ali havia para ela. 
Saber que estava ali essencialmente para ajudar as pessoas era importante. Estava ali para fazer uma performance, e isso faz parte do meu caminho. Mas não estava ali para provar nada. Podia ter dado tudo errado. Mas isso na verdade era impossível, pois eu estava ali, assim como todos que se sentaram à mesa, cheia de perguntas e atrás de respostas. Eu tinha perguntas e não tinha respostas. Portanto, não tinha um ponto onde chegar. A performance era em si a pergunta, era a materialização da pergunta e sua ação em busca de respostas. E eu simplesmente perguntei.

Eu estava ali para contribuir no que eu pudesse. Estava disponível. Não havia promessas, apenas o presente da carta. Eu poderia contribuir em algo? Poderia ajudar em algo? Poderia fazer uma carta?

Eu estava disponível para ajudar com o que pudesse, com o que eu tinha. $E$ a gente nunca sabe o que a gente tem até compartilhar com alguém, até de fato dar um presente. 
Os desenhos eram simples, como aqueles que dizem ser de crianças. Eu nunca havia feito essa performance antes. Não havia feito um teste. Não sabia o que iria desenhar, que tipo de desenho ou técnica iria utilizar. Aconteceu. Simplesmente.

$O$ desenho era simples e o ato singelo. Mas as pessoas sempre choravam. Se não choravam por fora, choravam por dentro. Os olhos, os movimentos, as expressões, as viradas dos olhos, do corpo. Tudo me mostrava que aquilo que estávamos conversando era realmente importante. 
Dentre as conversas que mais me chamaram a atenção, houve uma moça que estava ali esperando seus filhos saírem da aula de dança.

Ela ficou muito entusiasmada e começou a contar situações extremamente íntimas. E gradativamente, cada vez mais íntimas. Ela ficava espantada. Como, de repente estava contando tudo aquilo para mim? Como estava ali, no meio de todos, contando coisas que ela nunca havia contado para ninguém? Ela dizia espantada que parecia que havia uma abóboda que protegia a gente no meio daquele monte de gente, e que fazia com que só eu pudesse ouví-la e mais ninguém. Ela não sabia, mas tinha razão. $O$ que acontecia ali a deixava impressionada e em determinado momento ela passou a perguntar sobre mim. Quem eu era? O que eu era? Quantos anos eu tinha? (minha aparência jovem deixava as pessoas em conflito).

Nesse momento eu comecei a responder algumas perguntas. Ela me fazia perceber que eu era uma pessoa comum, ou melhor, que era justo que de alguma maneira eu demonstrasse isso. Ela me mostrou uma faceta relevante do trabalho, que era explicitar que somos iguais, e que apenas aquele era meu trabalho, assim como cada um tem o seu trabalho. Aquele espaço, aquela ação, a própria performance em última instância traziam isso.

A performance carregava minha pergunta sobre se aqueles conhecimentos eram para todos ou para um grupo restrito. Eu acredito que são para todos, por isso estava ali. Fiquei feliz. 
Parecia-me justo responder a suas perguntas, uma vez que aquilo parecia proporcionar uma quebra de hierarquia e uma possível relação de poder. Eu não sou detentora da verdade, nem estava ali para exibir possíveis poderes advindos de forças sobrenaturais. Eu estava ali apenas para fazer meu trabalho.

Mas em determinado momento, após responder algumas perguntas, eu percebi que esse não era o foco. Então voltei as atenções para ela e para a carta.

Ela ficou muito emocionada e extremamente agradecida. Ela queria meu endereço para me enviar uma carta na qual contaria o que havia acontecido depois daquela experiência. Parecia ainda querer abrir a possibilidade de trocas de correspondências comigo. Eu respondi que a performance estava marcada para acontecer somente ali, naquele momento. Que talvez pudesse acontecer de novo. Mas que se ela quisesse, poderia deixar sua carta na Praça das Artes que eu receberia.

Ela não queria ir embora. Queria me ver de novo e queria dar continuidade no processo. Mas logo percebeu que havia uma fila depois dela. E se foi. 
Houve também um moço muito angustiado, ele - como muitos outros - havia se apaixonado por uma trabalhadora do sexo e queria convencê-la a se casar com ele. Sua angústia me chamou muita a atenção. E me fez perceber como estamos a todo momento lidando com sentimentos, histórias e memórias na relação com as pessoas. Eu não precisava estar conversando com ele. Mesmo que eu estivesse apenas do seu lado na fila, ou que o esbarrasse no caminho, ainda assim estaria lidando com tudo isso. No dia a dia, esquecemos disso. Esquecemos que estamos lidando com tudo e com todos a todo momento. E esquecemos de cuidar disso e da importância de cuidarmos uns dos outros.

Uma das pessoas que por último se sentou na mesa, era um jovem, universitário, cuja esposa era taróloga. Ele já tinha algum conhecimento sobre o tarô, mas ficou curioso pelo processo, pelo trabalho e aproveitou a oportunidade. 
A performance aconteceu com uma variedade de pessoas e demandas. Foi um processo de grande aprendizado. Ela estava inicialmente programada para acontecer entre as $17 \mathrm{~h}$ e $19 \mathrm{~h}$, mas a grande fila de espera que se formou e a ausência de um aviso do horário fizeram com que eu decidisse ficar até que a Praça das Artes fechasse, às $21 \mathrm{~h}$.

Ao fim percebi como a performance mesmo num espaço público e urbano como o centro de São Paulo, continuava a operar num espaço íntimo, que se instaurava pela ação. A dimensão não espetacular e ritualística permaneciam. Muitas cartas eu sequer fotografei. Deixei este presente em segredo para quem era seu destino em forma de carinho. 
Lembrei.

No início, meu maior desejo ao estudar artes era entender como os desenhos do tarô conseguiam transmitir todas aquelas mensagens. Como funcionavam? De onde vinham? Como foram criadas? Como se originaram? O que elas dizem? Como? 


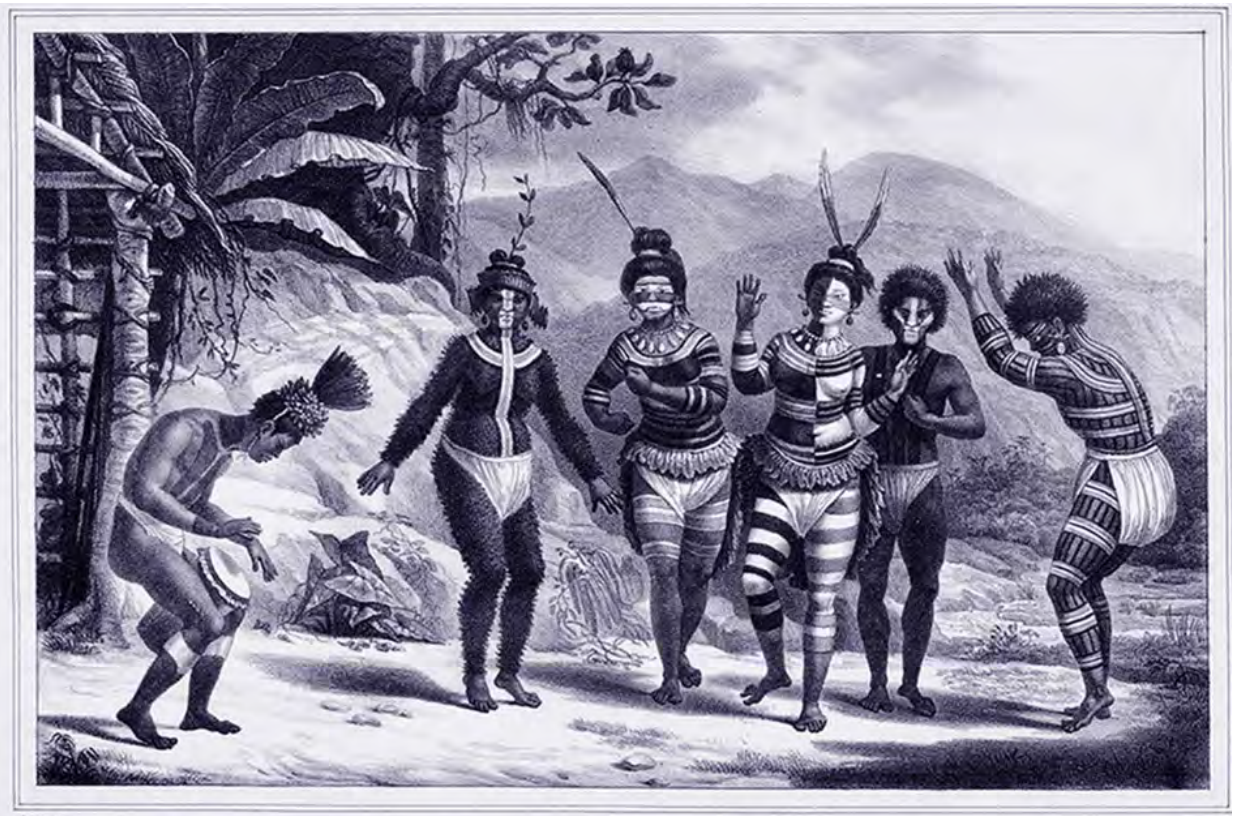




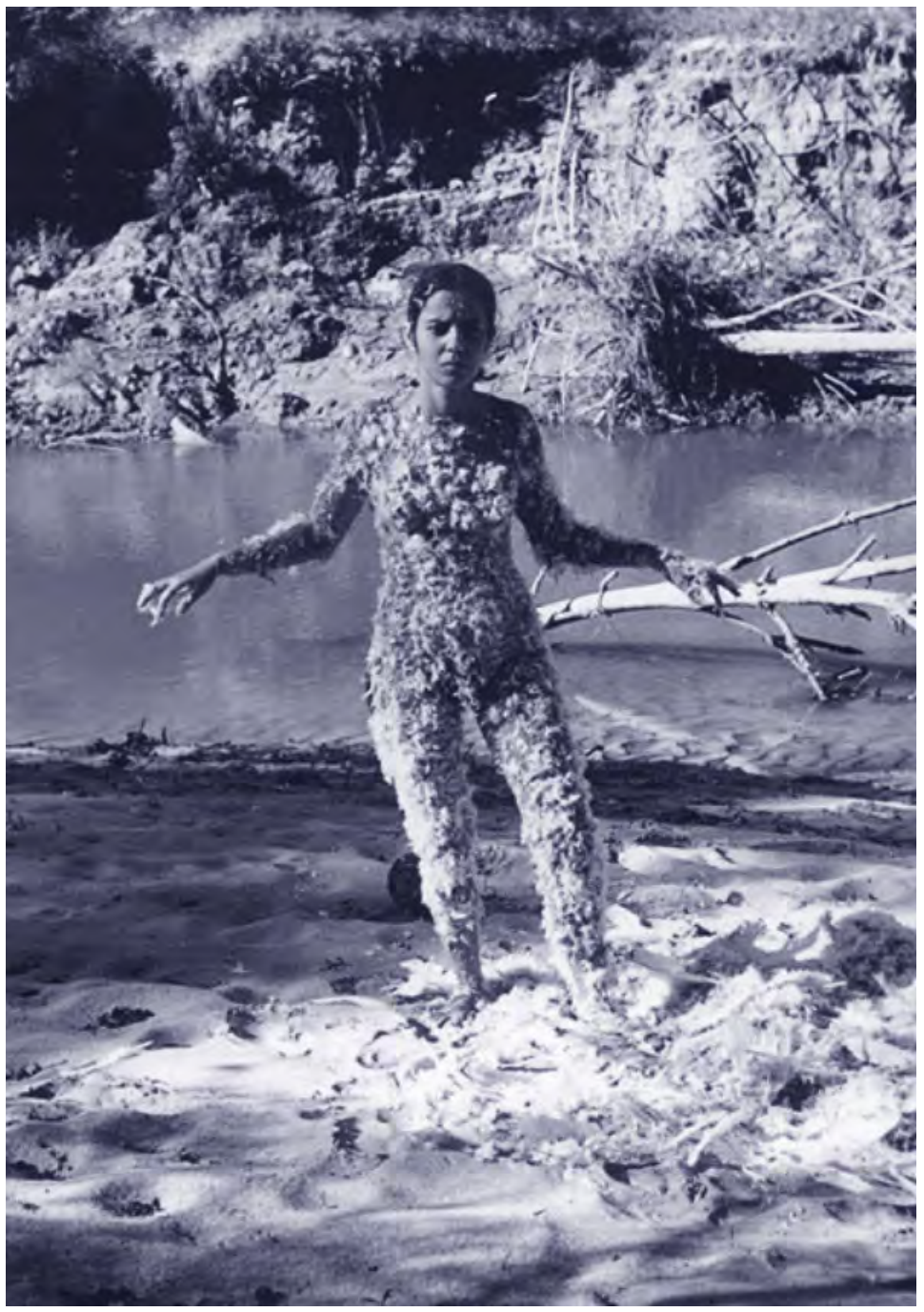


<smiles>C1=CC2CCC(C1)C2</smiles> 


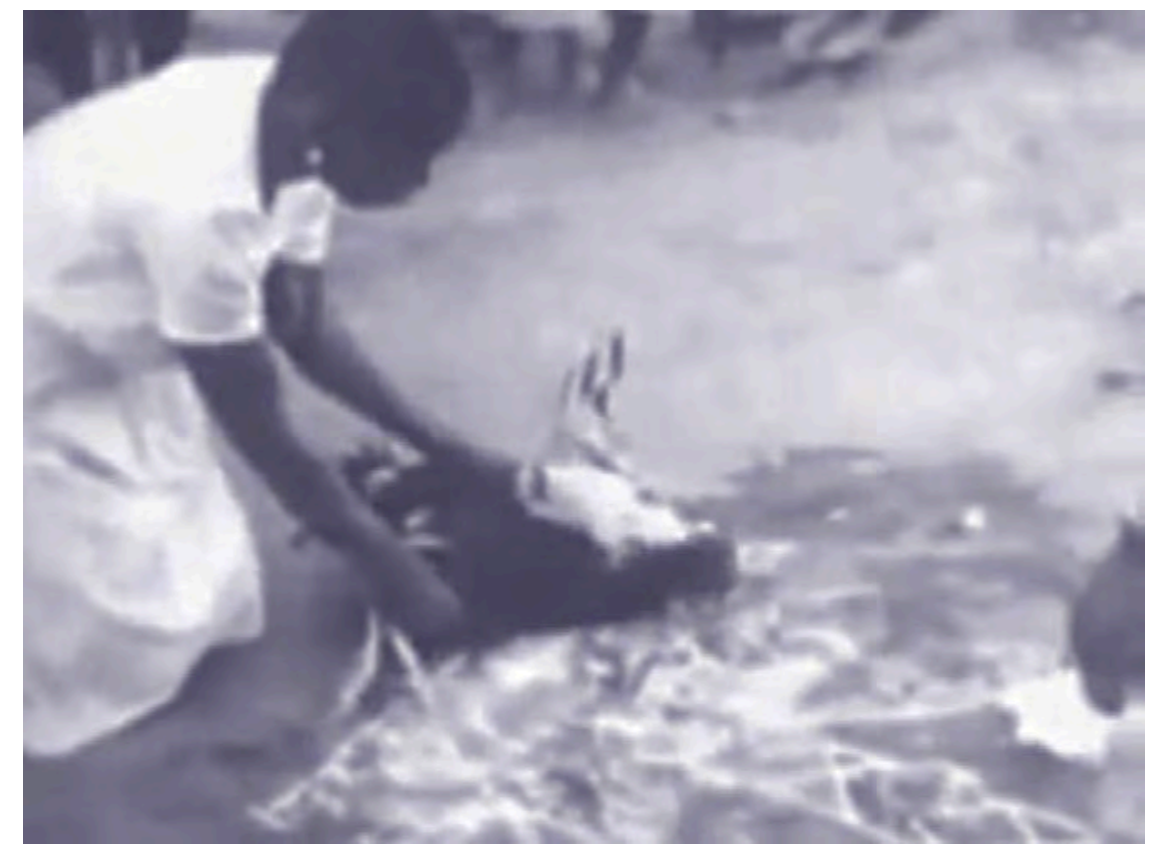




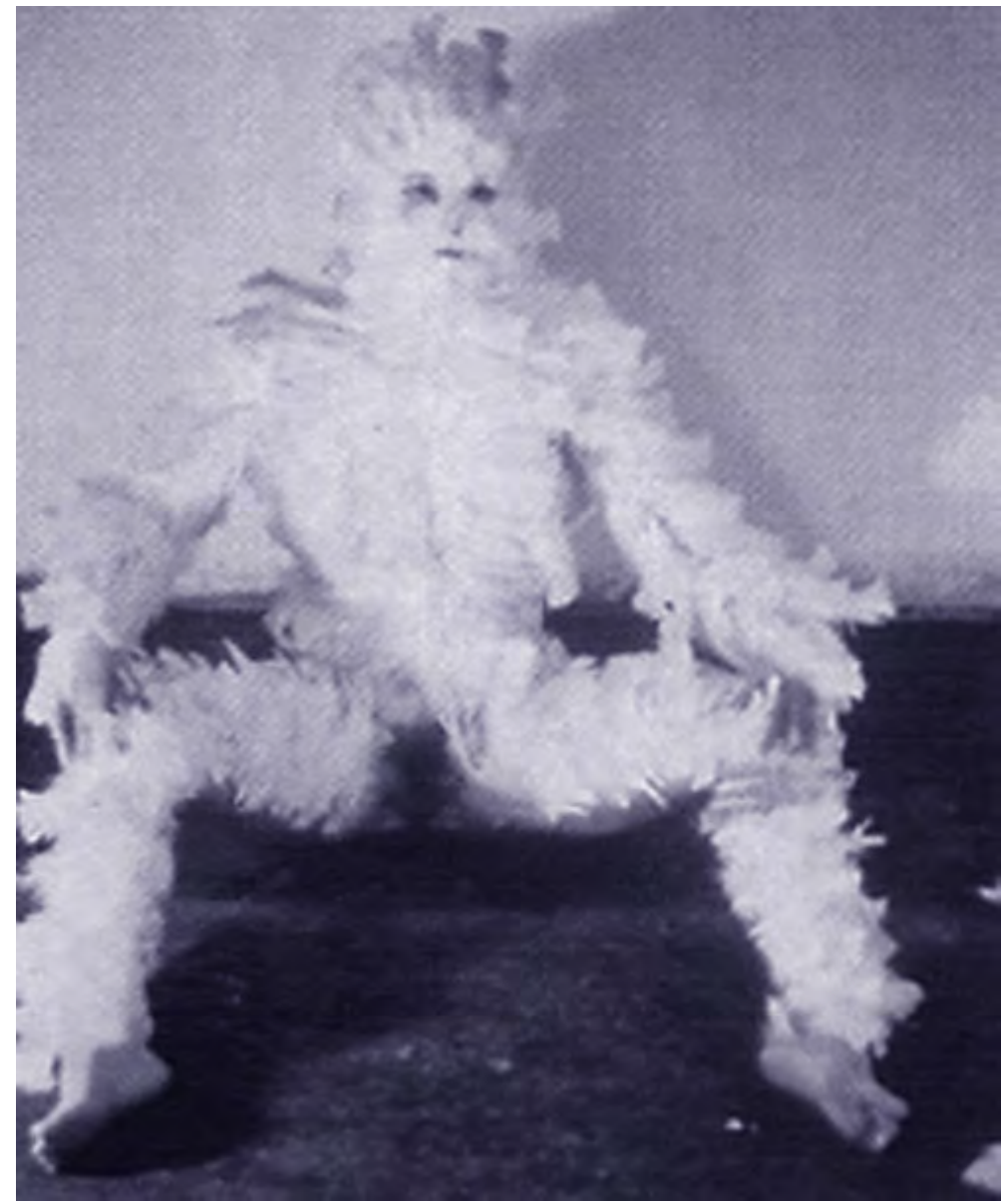




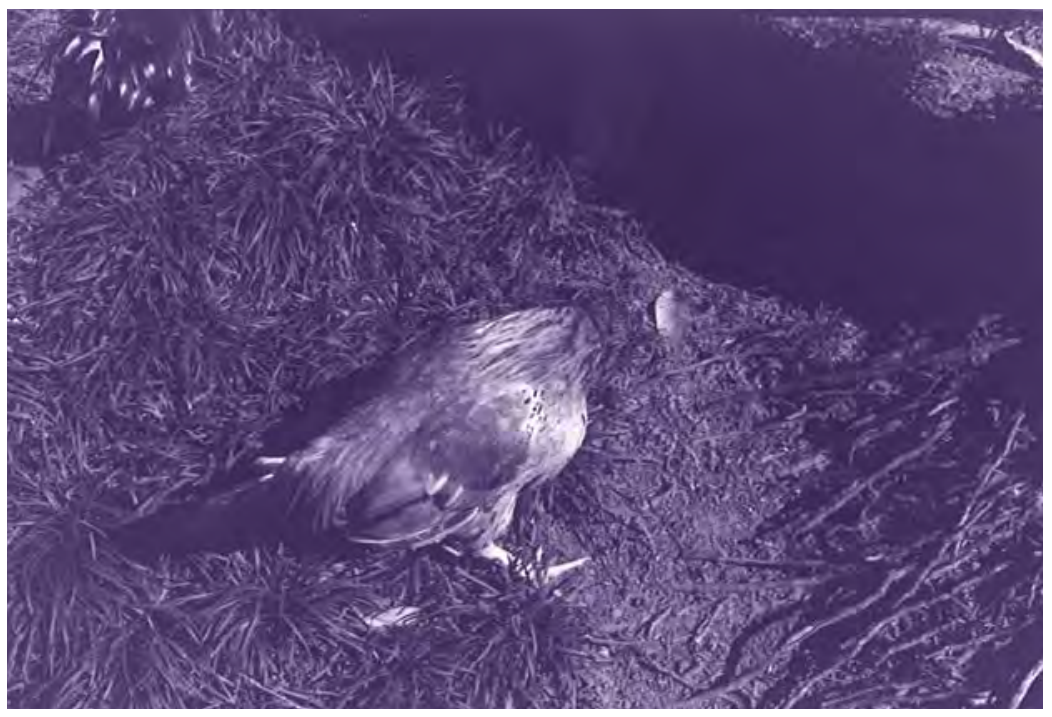




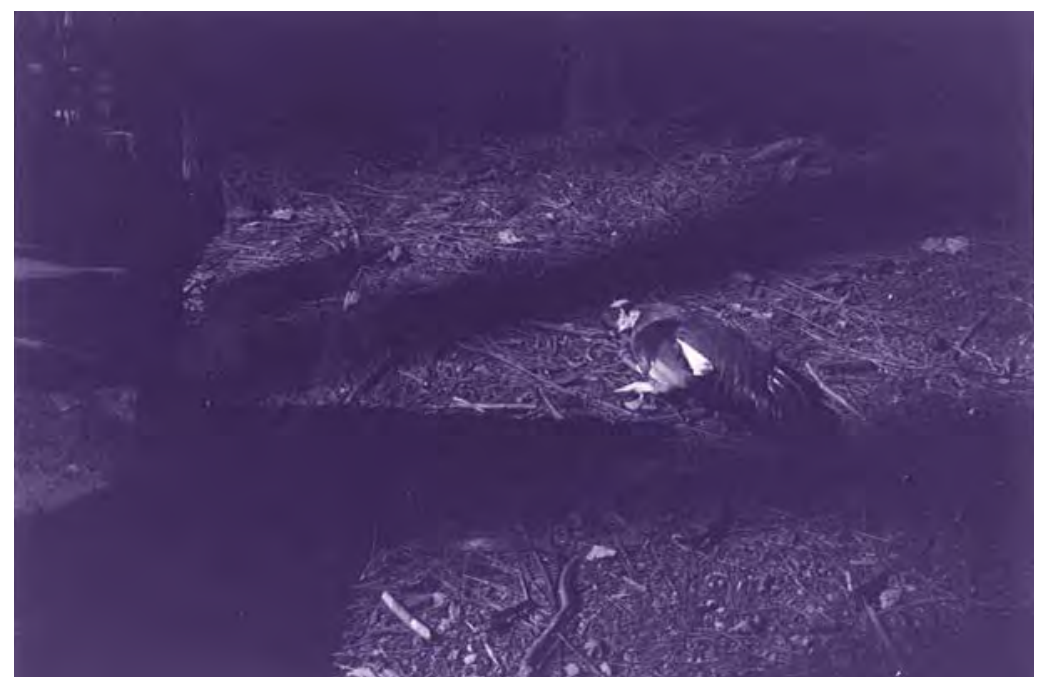




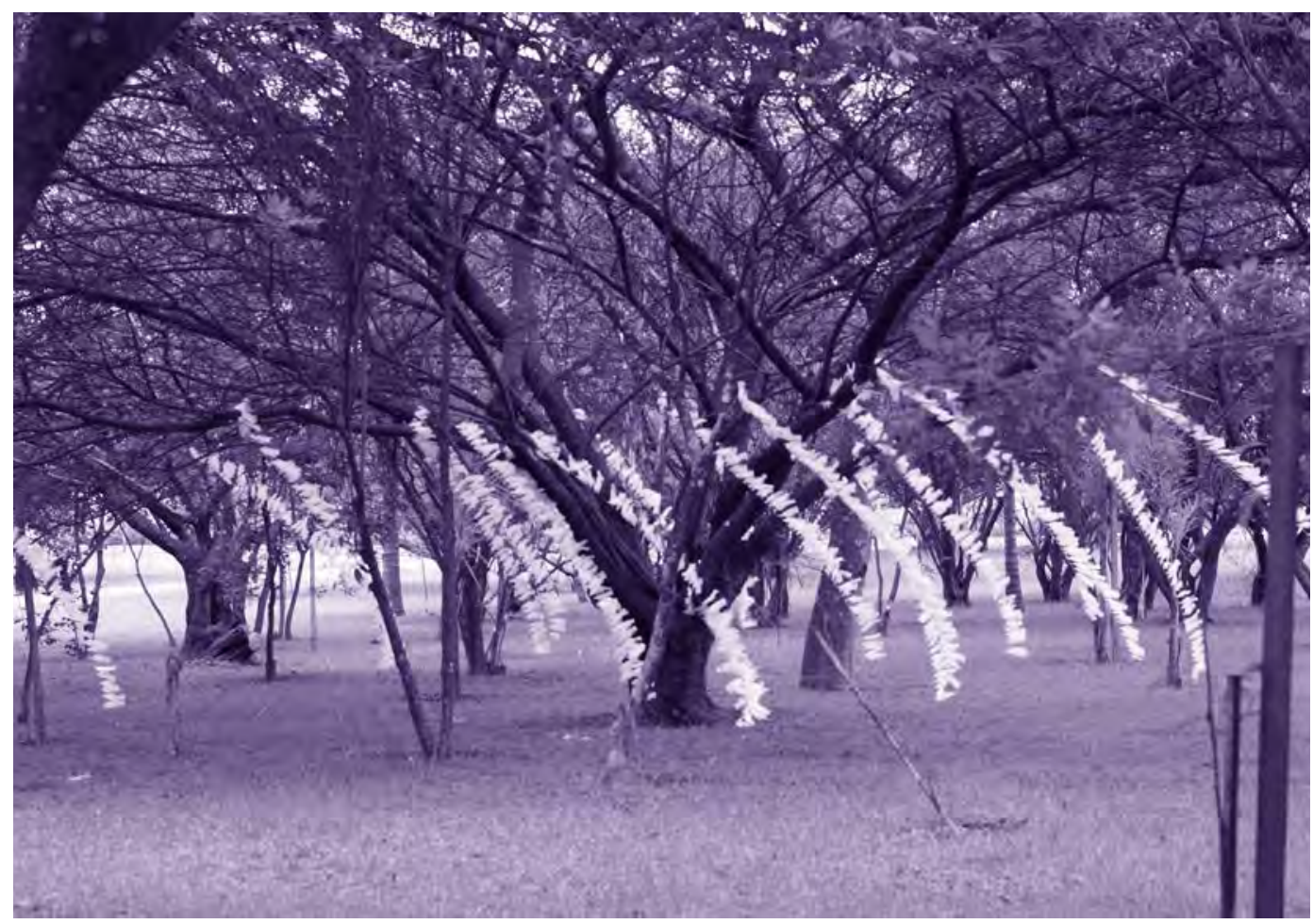




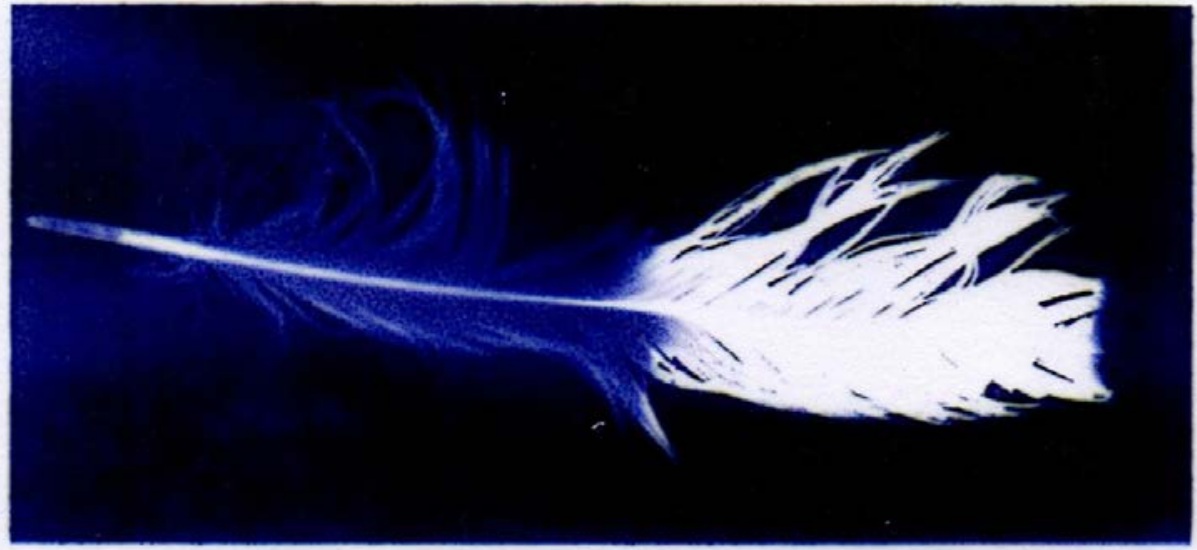

puente 


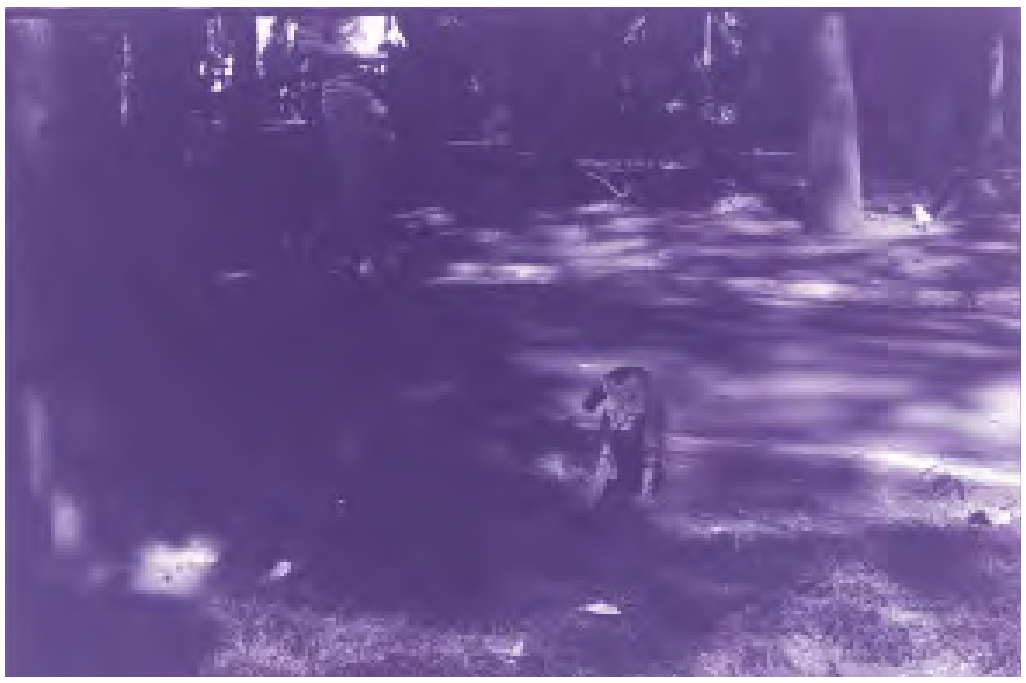




\section{O invisível pode modificar o visível? \\ Andar e tatear no escuro ou no claro absoluto? \\ A luz e a sombra são o in- visível que permite que tudo apa- reça.}

Faço meu caminho 
Mar em vazio

o porvir que já existe

e não se sabe 
Não veem que o poste é mole?

Que até o concreto possui seus segredos

Sim, os objetos tem vida

A matéria toda possui sua magia

Há muitos espaços vazios

Existem muitas letras e sentenças

Todas desenhadas em letra

maiúscula

Em forma de oração escrita

E pronunciada

Que fazem os olhos ver e as mãos balançar uns dos outros

Você e as mesas

Mas que não se aconselha ninguém a ver

Ninguém a ouvir,

Nem a encontrar 
É presença enquanto "ser" que se torna na duração em que a ação acontece. Enquanto materialidade, assume formas e corpos próprios sempre se dando em relação ao meu próprio corpo, na qual eu sou sempre testemunha, ainda que para outros se torne ausência. É presença que se dá numa apropriação afetiva, de embate com o corpo, com a materialidade, com a comida e a sexualidade, com o corpo imbricado na ação magística ritual em performance. Uma presença de camadas infinitas, de ação sutil, no entanto efetiva enquanto ação e criação no mundo. A presença espectral se dá nesse jogo de lugares do presente, do efêmero, muitas vezes impalpável, no entanto, materializado, residindo na ambiguidade do espaço e tempo "entre", mutável, indetermidado. 
duplo

espelho

imagem de si 
eu sou água que faz dedilhar rarefeito com o vento eu sou transparente transparente de verdade transparência que cega e deixa perdido sem saber o fundo tomo conta do desavisado que em despreparo já não sabe onde está 
NATUREZA

$+$

ANIMA

PERSONIFICAÇÃO = $+$

SENTIDOS

$+$

INTELIGÊNCIA

$+$

AÇÃO 
Os toques de Camdomblé, de onde vêm? Que som fazem? Infrassons. Sons construídos de pedacinhos de infrassons em uma sequência arquitetônica; de matéria variável, que traz o que tem que trazer.

São rezas. Sua repetição faz o Pai Nosso e a Ave Maria. A cachoeira é assim. Um toque in natura infinitamente exclusivo que chama em outro plano e é morada tangível. 
Os espíritos

A espiritualidade não trata somente dos mortos

Mas de diversos tipos de seres

Seres que nem são sabidos os nomes

Espiritualidade é um nome genérico que abarca tudo aquilo que trata da vida,

do material no encontro do imaterial e o inverso simultaneamente

não se trata somente de lidar com os mortos

De evocar

De ver

Aquele que atua na espiritualidade vê todos os mundos e seres a todo momento

Para quem olha sentado na grama, a paisagem pode parecer estática

A feiticeira sempre vê o balanço. 
mEDITACÑO DANCA

SUSPENEÃO

timpo tempo tampor ten yp

Silêncio

PAUSA

Golpe certsiro

LUTA 


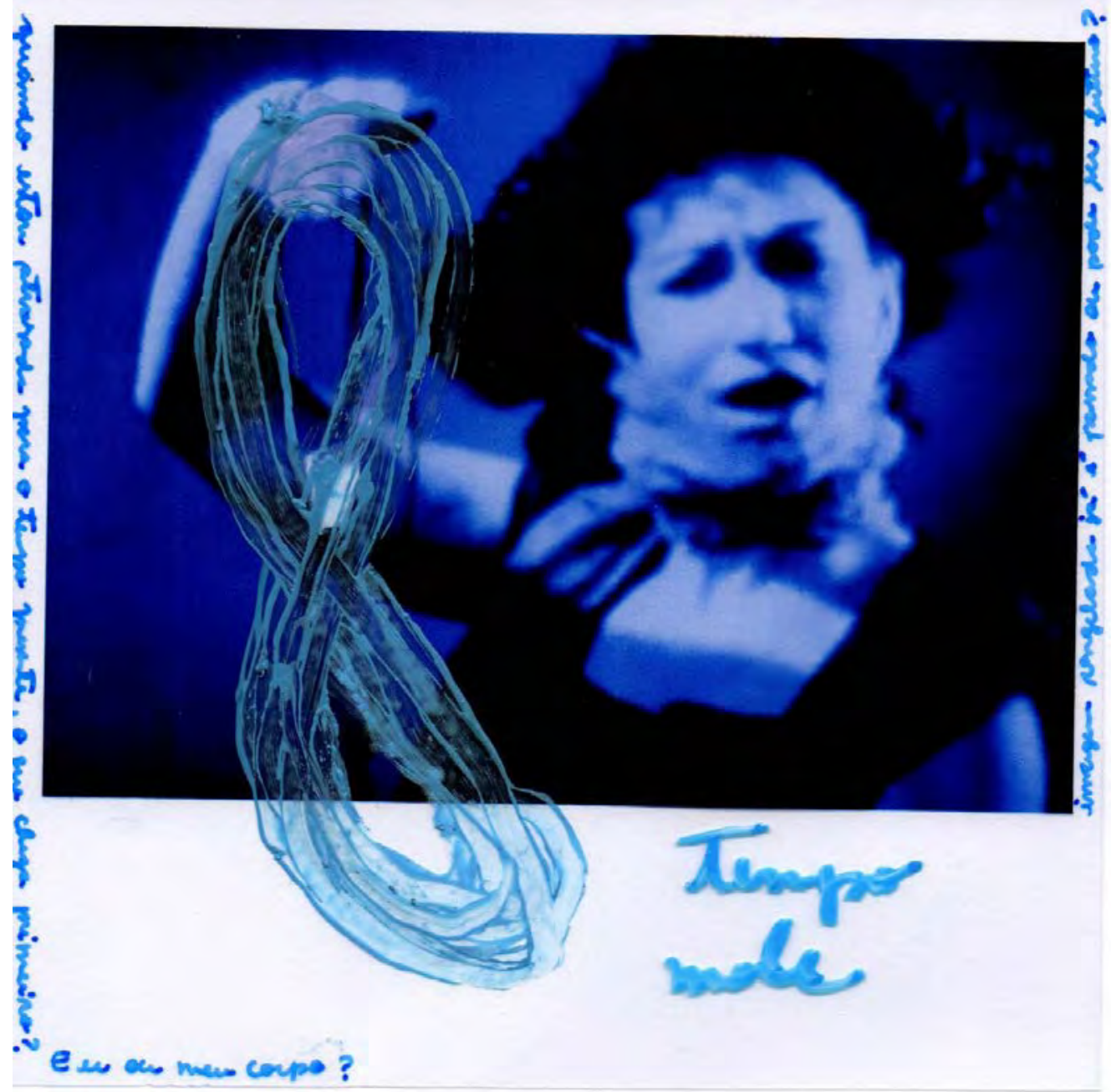




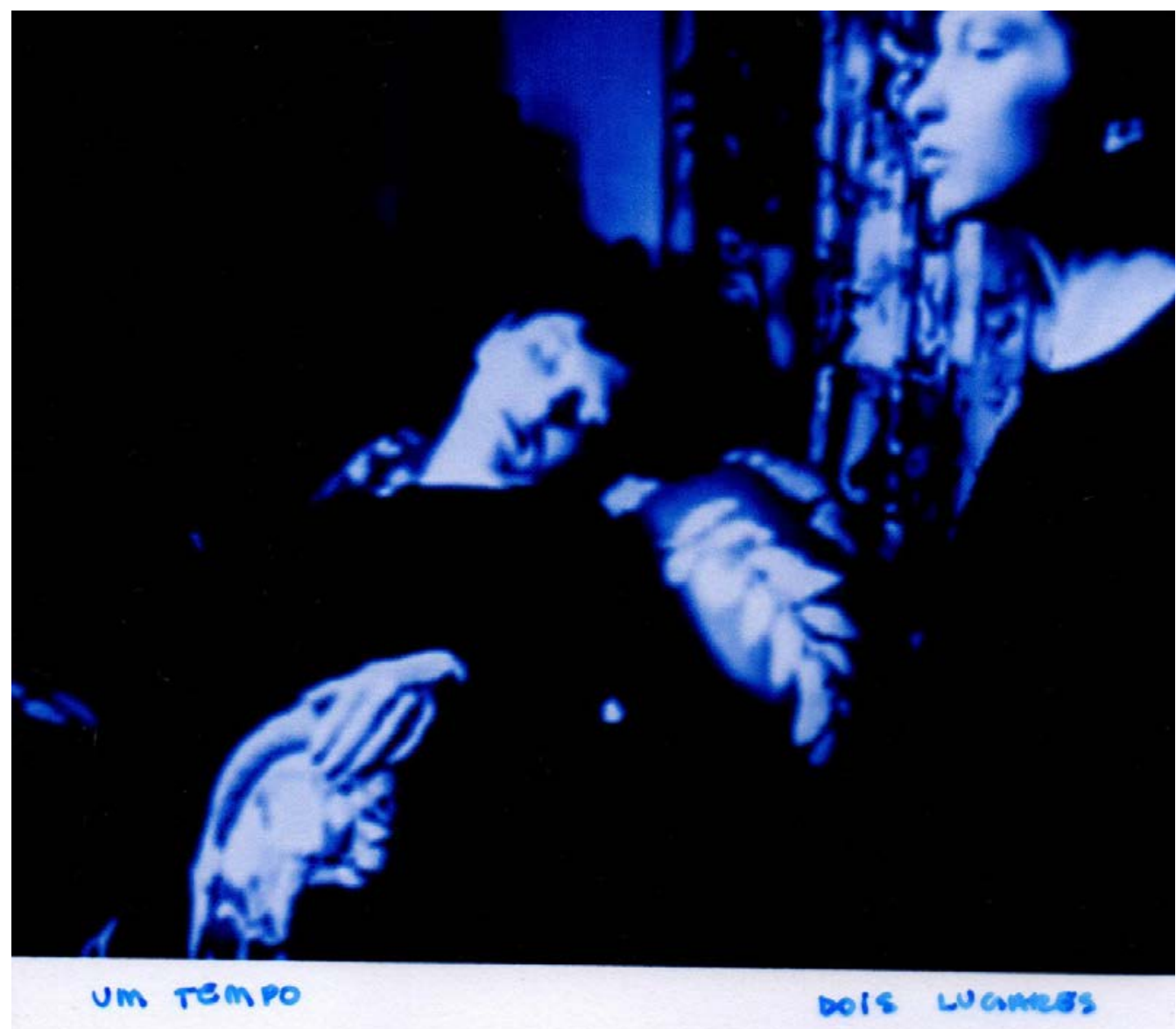




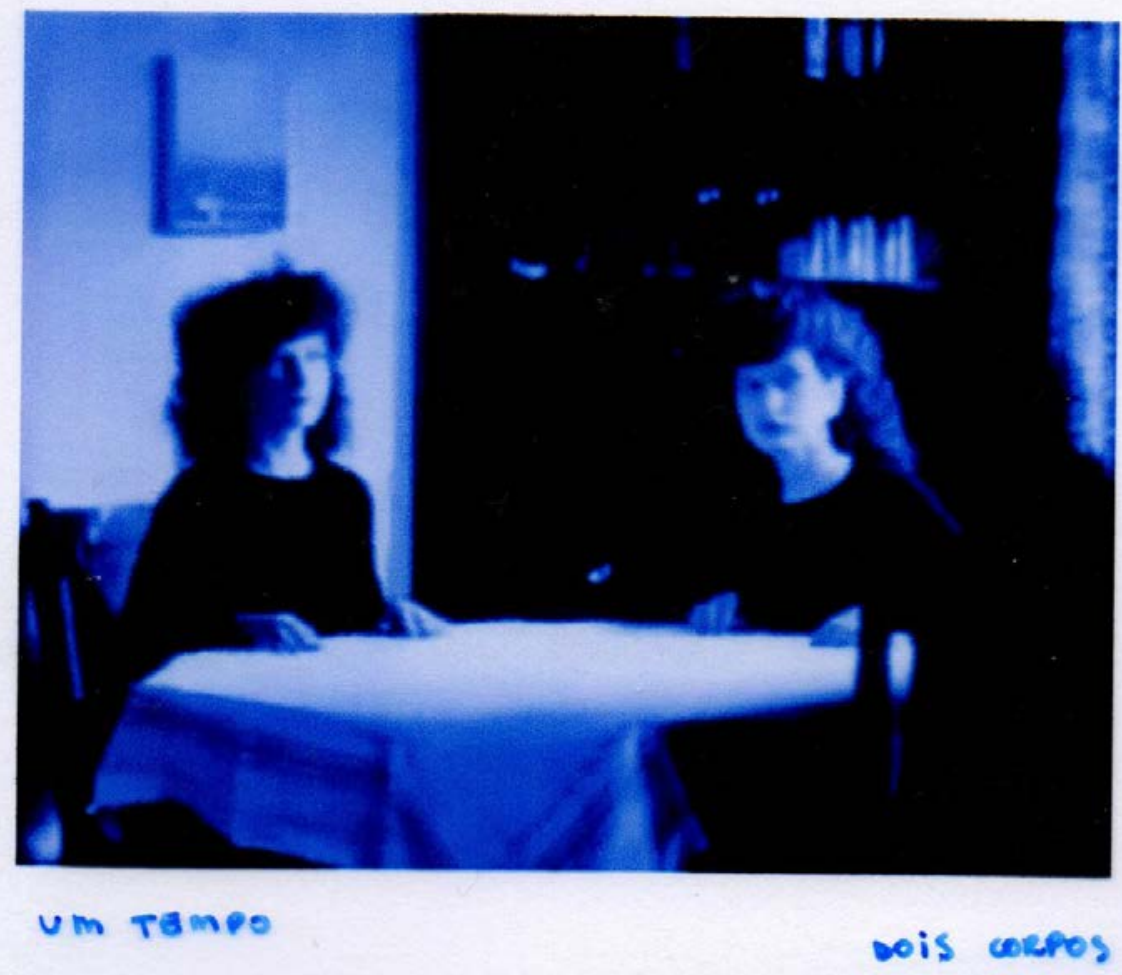



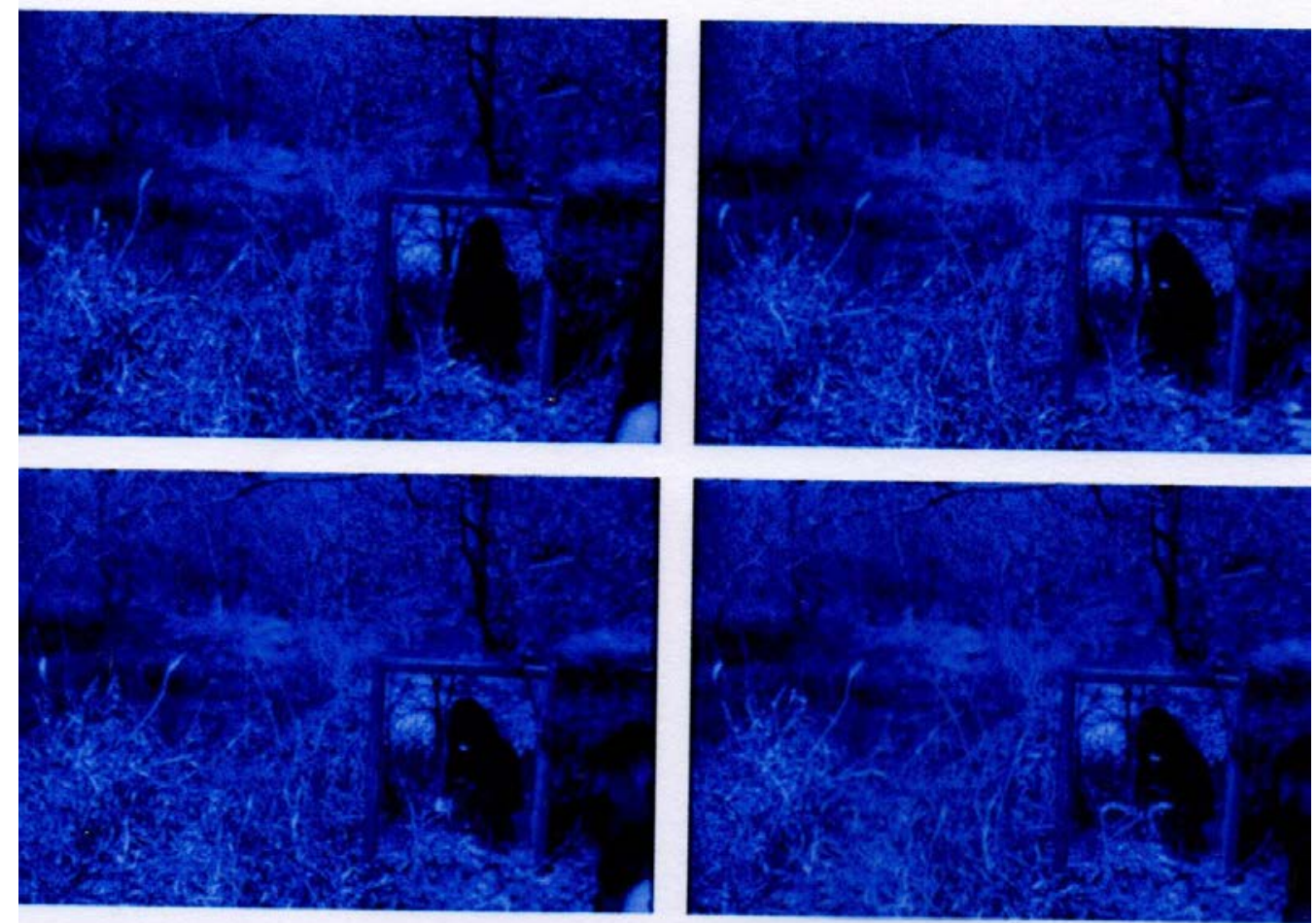

\section{mire aem}




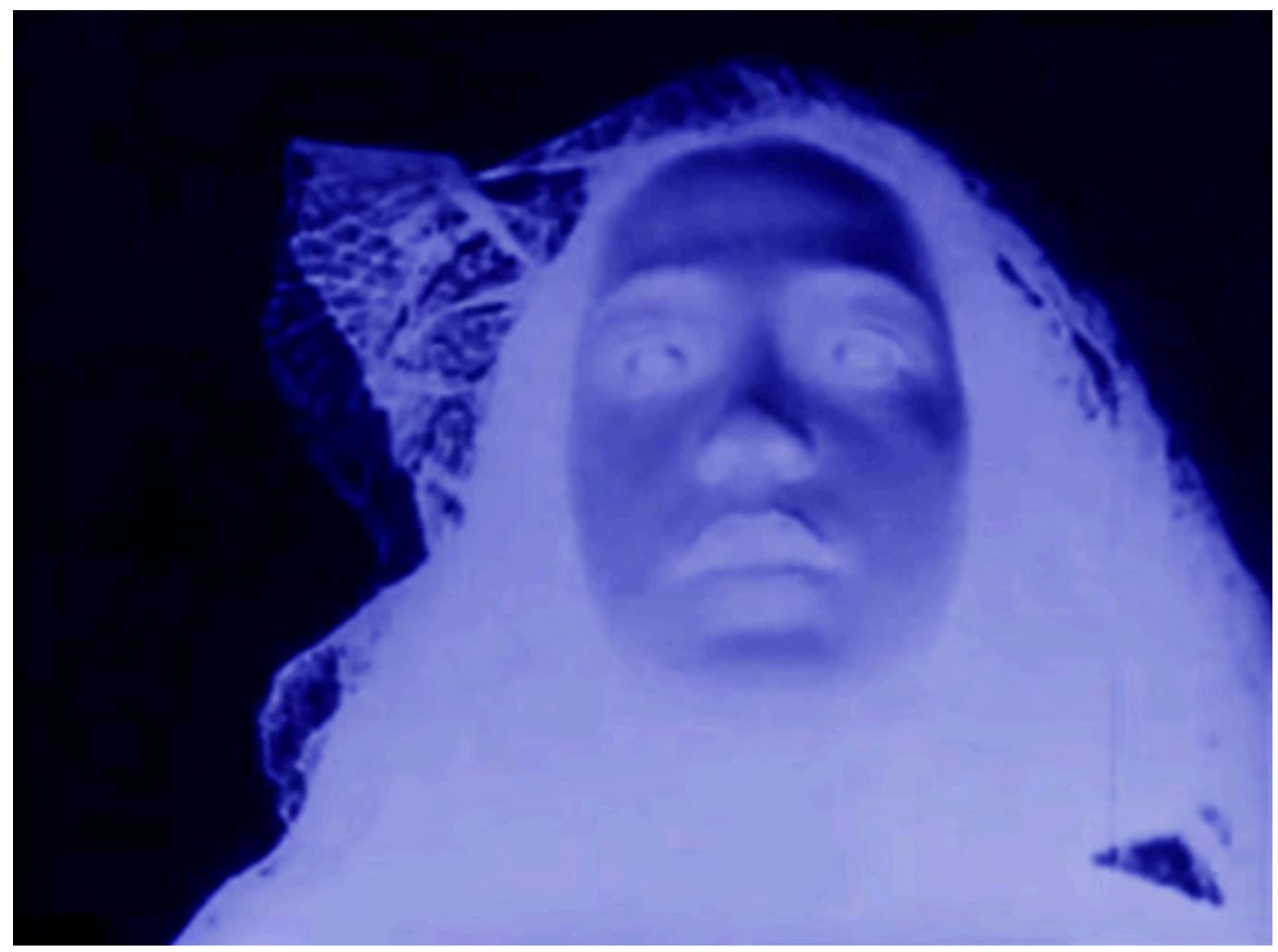


Escritos II 
Autorizo a reprodução e divulgação total ou parcial deste trabalho, por qualquer meio convencional ou eletrônico, para fins de estudo e pesquisa, desde que citada a fonte.

\section{Catalogação na Publicação}

Serviço de Biblioteca e Documentação

Escola de Comunicações e Artes da Universidade de São Paulo

Dados inseridos pelo(a) autor(a)

Cavalcante, Kim

O Corpo, A Artista e A Feiticeira / Kim Cavalcante. --

São Paulo: K. Cavalcante, 2018.

215 p.: il. + DVD.

Dissertação (Mestrado) - Programa de Pós-Graduação em Artes Visuais - Escola de Comunicações e Artes / Universidade de São Paulo.

Orientador: Luiz Claudio Mubarac

Bibliografia

1. Artistas Mulheres 2. Performance 3. Espiritualidade 4. Corpo 5. Descolonização I. Mubarac, Luiz Claudio II. Título.

CDD 21.ed. -700 
O conjunto de trabalhos artísticos apresentados equivale à dissertação de mestrado O Corpo, A Artista e A Feiticeira, constituída por: um DVD com vídeos e fotografias dos trabalhos de performance Intervalo (2016), Saia Sonoral O mar não encena (2016), Experimentos de Jardim (2016) e Artista Feiticeira (2017); um livro de artista formado por 125 lâminas de transparências impressas que formam um corpo de constituição própria que é em si um experimento sobre o que foi produzido, levantado, desenvolvido, formulado e reformulado na pesquisa; e o livreto Escritos II, impresso em papel sulfite, onde aponto através de anotações o caminho percorrido durante a pesquisa, explicitando trabalhos artísticos, artistas, autores, ideias e reflexões encontrados durante a investigação, que permeiam e constituem o material apresentado. 



\title{
O Corpo, A Artista e A Feiticeira,
}

por Kim Cavalcante. Dissertação apresentada ao Programa de Pós Graduação em Artes Visuais da Escola de Comunicações e Artes de Universidade de São Paulo, como requisito parcial para a obtenção do título Mestre em Artes Visuais, sob orientação do Professor Doutor Luiz Claudio Mubarac

\author{
APROVADO EM
}





\section{Agradecimentos}

\section{Agradeço}

À minha mãe, ao meu pai e às minhas irmãs Sarah Cavalcante e Liah Cavalcante.

À minha família espiritual.

Aos amigos Célia Boregas, Yara Moreno, Mahara Mathias, Mariana Aguiar, Talita Lima, Brunna Laboissiere, Guilherme Minoti, Eloy San Carlo, Monilson Rasteli, Bárbara Kanashiro.

Ao querido Keisser Montaño.

Ao Pinguim e ao Núcleo de Artes Afrobrasileiras.

Aos orientadores Luiz Claudio Mubarac e Mário Celso Ramiro.

Aos técnicos Olavo, Donizete, Milton, Henrique, Valdir, Nivaldo e Vanderlei, às secretárias Solange, Stela e Regina e aos professores e funcionários do Departamento de Artes Plásticas da Universidade de São Paulo. 
Do Outro Lado do Espelho 
Sou Kim Cavalcante. Tenho 28 anos. Quase toda minha família nasceu no estado do Pará - região de relevante presença indígena. Meus avós maternos são de cidades do interior do Pará. Meu avô nasceu em uma cidade ribeirinha - Cametá. Era vendedor. Ele faz garrafadas e toma açaí com carne todos os dias, sem falhar. É católico fervoroso e torce para o Remo. Quando eu era pequena ele raspava a maçã com colher para mim. Hoje ele faz mocotó pra mim, no fundo do quintal, no carvão, num latão de óleo. Minha avó fugiu de casa porque seu pai era um índio muito bruto, e sua mãe a maltratava demais. Era faxineira, manicure e cozinheira. Ela gosta muito de fazer mocotó e feijão com maxixe. Às vezes compra galinha pra alimentar e matar em casa. Hoje ela é evangélica, mas minha mãe conta que se lembra dela a levando pequena em terreiro que tinha perto de sua casa.

Meu avô paterno é do Pará também. Sua família tinha muitas posses, mas perderam tudo. Ele teve muitas esposas. Quando era mais velho, estudou direito e virou juiz. Lembro-me de comer tartaruga em seu restaurante. Quando ele morreu, entregaram ao meu pai seus documentos da maçonaria. Minha avó paterna é de Pernambuco. Ela voltou para escola depois de já estar mais velha. Fazia faxinas em casas. Ela adora um forró. É uma negra alta, sempre muito bem vestida, perfumada e cheia de pulseiras. Ela mora sozinha. Não quer morar com filho nem com namorado. Ela frequenta às vezes uma igreja católica com minha tia, mas quando era mais jovem frequentava terreiro.

Meu pai nasceu na llha de Marajó, no Pará. É editor de vídeo. Atualmente trabalha na Igreja Universal. Ele é ateu. Ele gostava muito de cozinhar, mas parou de preparar algumas coisas depois que fez cursos de culinária. Minha mãe nasceu em Belém. Foi funcionária pública e hoje é 
aposentada. Ela não gosta muito de cozinhar, mas gosta muito de comer. Na minha casa, minha mãe sempre fazia suco. Nunca de caixinha. Durante muito tempo ela foi médium em centro espírita.

Eu vim de Belém na barriga da minha mãe e nasci em São Paulo. Cresci na zona Leste de São Paulo, entre os bairros de São Miguel e Itaquera. Aprendi a sambar aos 3 anos.

Quando eu era pequena, minha mãe me contava histórias da tia Zizita. Era a tia da minha mãe. Ela contava histórias de assombrações, de galinhas que começavam a crescer até maiores que uma casa, de velhinhas que viravam bicho e comiam animais. Eu amava ouvir essas histórias. Tia Zizita era o correio de Cametá. Ela ia de barco, levava cartas para as pessoas e avisava quem ia morrer. Ela tinha visões - como as pessoas diziam.

Minha mãe ia para Igreja porque senão não comia. Depois de sair da casa de seu pai, passou a frequentar centro espírita e a trabalhar como médium. Ela me levava com ela quase sempre.

Quando eu era adolescente, dava pra ouvir da minha casa toques muito bonitos que vinham da ocupação que ficava ali perto. Eu pedia para minha mãe me levar lá. Ela prometia que me levaria, mas nunca levava.

Aos 19 anos entrei para a faculdade, onde fiz uma graduação em Artes Plásticas. Foi nesse período que fui pela primeira vez num terreiro.

Durante a graduação foi também que conheci o Núcleo de Artes Afro-brasileiras na Universidade de São Paulo. Foi lá que eu voltei a dançar. Desde os cinco anos eu comecei a participar de apresentações em 
academias de dança. Durante a adolescência participei de uma companhia. Meus professores, treinadores e diretores queriam que eu fizesse faculdade de dança ou teatro. E cheguei mesmo a cogitar fazer dança.

O NAAB é comandado pelo mestre Pinguim. Lá, ele dá aula de capoeira, dança e percussão. O espaço mantém uma relação direta com a Bahia, com o Candomblé, sua arte e cultura. Dentro deste intercâmbio, acontecem atividades com mestres de capoeira, de samba, tocadores, babalorixás, yalorixás e representantes de diferentes manifestações. $O$ espaço recebe e acolhe também a visita de artistas e grupos de dança das mais diversas modalidades. A culinária também é uma arte imprescindível no espaço. O hábito de comer pipoca, feijão e tomar cerveja fazem parte do aprendizado. Acontecem festas em que cozinhamos, tocamos, dançamos e cantamos.

Com o Pinguim, nós aprendemos das coisas mais preciosas da vida. Ele é briguento e brincalhão; ensina através da arte e cultura sobre coisas muito sérias: sobre nosso espírito, nossas energias, nossa respiração, como se manter bem, como tirar as toxinas, respeito, sociabilização, ressocialização e união.

Através de um edital da universidade, realizei um intercâmbio no México. Conhecer o México me trouxe uma melhor compreensão sobre a representatividade indígena. Enquanto no Brasil essa representatividade se dá principalmente através de marcos históricos e a um imaginário ligado a uma ideia de tempo passado - como o "descobrimento do Brasil", a data comemorativa do dia índio, uma mitologia do primitivo e do selvagem, ou um imaginário da Amazônia -, no México, ela se dá através pessoas vivas. Uma população notoriamente indígena toma conta do país 
com sua arte e cultura, manifestações e tradições, além do famoso governo zapatista que inspira diversos movimentos pelo mundo. No Brasil, os indígenas são como fantasmas. As pessoas tem dificuldade em reconhecer fisicamente traços indígenas. Uma identidade que parece viver no passado das histórias das navegações marítimas, nos desenhos de artistas viajantes do período colonial que contam sobre um povo estranho não civilizado que morreu. Essas duas realidades me ofereceram uma concretude sobre o extermínio físico, simbólico, político e ideológico da população indígena no Brasil e sobre as dificuldades da luta de resistência dessa população, que tem que lutar até pelo direito humano mais universal que é o direito de existir.

Quando eu terminei a graduação, saí de São Paulo e e fui morar em Acupe - uma vila de pescadores no Recôncavo da Bahia. O Recôncavo é um lugar que parece guardar um bálsamo nutritivo que alimenta a alma de qualquer um. É forte e intenso. Mata ou ressuscita.

Um tempo depois, voltei para São Paulo no intuito de realizar o mestrado. Mas esse meio tempo fez reacender parte do meu coração que havia sido deixado de lado devido à dedicação acadêmica. Então, voltei a me dedicar aos estudos de cura chamados alternativos. Investi parte do meu tempo em cursos livres de massagem, fitoterapia, aromaterapia, Ayurveda, florais, entre outros. Iniciei também um curso técnico em enfermagem. Muito do que eu sabia vinha, na verdade, de estudos autodidatas e de anos acompanhando minha mãe, seja como filha ouvindo suas histórias, tomando seus chás e remédios com ingredientes muitas vezes vindos do Pará, como também pelo fato de que ela já havia se envereda- 
do por este caminho, atuando como terapeuta e dando aulas.

Ao iniciar o mestrado, constatei que seria inviável continuar com o curso técnico naquele momento. Mas passei a trabalhar numa clínica como terapeuta holística. Lá eu fazia atendimentos de tarô, de aromaterapia, equilíbrio dos chacras.

Em 2016, participei como imersa na residência artística Afrotranscendence na Red Bull Station, em São Paulo, uma rede interdisciplinar que incentiva e promove a experimentação, a pesquisa, o conhecimento e a produção do pensamento crítico e artístico-cultural afro-brasileiro. No AfroT encontrei um ambiente em que as memórias, experiências e a ancestralidade ocupavam um lugar relevante, inclusive enquanto artistas. Essa residência me fez entender porque tantas vezes eu me encontrava em lugares de resistência negra, como a cultura indígena sobrevive e vive através da cultura afro-brasileira, e como a militância indígena, negra e feminista estão de maneiras muito próximas atravessadas pelo embate decolonial.

O prazer maior foi ter chegado até ali através de meu trabalho artístico e de minha pesquisa. Meu próprio trabalho poético falava ali comigo em diálogo com todos os outros artistas presentes, e me mostrava a preponderância da formação para o caminho à que minhas perguntas me levavam. 
Um Começo 
Ao pesquisar trabalhos de artistas que parecem ressoar questões de gênero, espiritualidade e performance, presentes em meu trabalho, deparei-me com um número relevante de textos que trazem discursos muito semelhantes.

A constatação da constância de dados biográficos abordados como fatores particularizantes, de trauma, ou patologia que marcam as análises de trabalhos artísticos de artistas mulheres foi o que impulsionou o princípio da pesquisa.

Tais discursos atravessam as análises sobre trabalhos poéticos de diversas artistas mulheres, levando a um caminho que por vezes os resvala do campo da arte, concentrando o foco processual do trabalho em questões que são aparentemente meramente subjetivas e particulares.

A constante deste discurso parece revelar, no entanto, a prevalência de uma perspectiva sobre as mulheres e seus corpos que os toma como potencialmente enfermos e propriamente histéricos - perspectiva que, muitas vezes, sequer coincide com o próprio discurso das artistas.

No caso de Ana Mendieta (1948-1985), por exemplo, uma tendência à dramatização de sua partida de Cuba, sua relação com sua terra natal e suas raízes, e seu possível suicídio aparecem invariavelmente como protagonistas em análises sobre o extenso trabalho de uma artista jovem, que mobilizou questões e linguagens diversas como, a body art, a land art, a fotografia, a performance, o vídeo, o feminismo e uma complexa pesquisa sobre o corpo, a presença, a ausência e a morte.

Ana Mendieta realiza em seu trabalho uma aproximação com o espaço e a natureza - assim como parece ocorrer com Francesca Woodman -, trata também de sua situação de imigrante e sua relação com sua terra Natal. Nas análises sobre seu trabalho, o não desvinculamento entre a 
artista (e seu corpo) com o espaço, a natureza, e Cuba, são elementos que aparecem associando o trabalho da artista à teoria freudiana sobre a construção dos limites do ego, segundo a qual essa sensação de não separação entre o ego e o espaço estaria relacionada a um não desvinculamento da "mãe". De modo análogo, este conceito também aparece em textos sobre os trabalhos de Yayoi Kusama e seus universos de bolas. Tal relação, recorrente em análises sobre o trabalho destas artistas, parece um tanto simplista diante da complexidade investigativa do trabalho artístico das mesmas.

Que Woodman tivesse questões existenciais e tenha se suicidado é uma coisa, seu trabalho é outra. Nem todo suicida foi fotógrafo, produziu vídeos, pesquisou sobre o tempo e a relatividade fazendo fotos. Que Yayoi Kusama tenha um diagnóstico psiquiátrico é uma coisa, que atue como artista é outra. Nem todos que recebem um diagnóstico psiquiátrico apresentam uma produção relevante como artistas.

A recorrência de tais abordagens sobre o trabalho de artistas muIheres acabam por reduzir, achatar, desvalorizar e desqualificar tais trabaIhos que envolvem uma pesquisa artística primorosa e rica. Tal perspectiva parece marcar as mulheres e seus corpos como naturalmente doentes, debeles e domesticados, uma vez que aparecem sempre como rodeados por problemáticas traumatizantes e que tomam por objeto questões meramente pessoais.

Este dado foi um dos primeiros impulsos da pesquisa, que se somou à investigação sobre a corporalidade e materialidade dos espíritos. 
Tendo como referência principal a espiritualidade afro-indígena brasileira, mas também outras próximas que a atravessam ou com ela dialogam na contemporaneidade, notei em diversos discursos uma aproximação entre estados de possessão, presença de espíritos, doenças, crença e loucura. Estas relações pareceram então conectar mulheres artistas e espíritos.

A crença, a doença e a loucura, quando tratadas como causas ou justificativas para a presença de espíritos levam igualmente a uma inferiorização, a um desprestígio sobre aquilo que pressupõe ou parte da ancestralidade e espiritualidade, tal qual acontece com as artistas muIheres. Ambos, as mulheres e os espíritos, parecem ser enquandrados como representantes do desvio, do mal, do impuro, e simultaneamente do misterioso, do incontrolável e por isso também do horror e do medo.

Tais relações são investigadas e desenvolvidas nesta pesquisa. Ao final do mestrado, a preponderância da perspectiva na construção destes discursos me levou a questões de formação, as quais remontam à colonização e toda problemática advinda deste processo, como a subjugação e exploração das mulheres, a escravidão, a dizimação indígena, o racialismo e racismo, a hegemonia masculina branca ocidental e a constituição das fontes tidas como oficiais do conhecimento. 
Artistas, Autores, Assuntos, Ideias e Reflexões 
Partindo de meu próprio trabalho artístico, que traz subjacente minha experiência, busquei por referências artísticas que com ele dialogassem.

Pesquisei então elementos presentes no trabalho: a imagem de si, o duplo, ou autorretrato; a ancestralidade, espiritualidade e cura e os espectros e suas materialidades.

A seguir, apresento em forma de anotações o material levantado durante a pesquisa, passando por artistas, assuntos, ideias e reflexões que a atravessaram. 


\section{Autorretrato}

O autorretrato de artistas mulheres são muitas vezes recebidos apenas como descrições de uma história pessoal, como um drama particular de um corpo potencialmente histérico. No entanto carregam um repertório próprio da experiência de um corpo coletivo específico - o corpo das mulheres. Esse repertório atravessa os trabalhos artísticos de um modo diferente daquele que não tem essa experiência, de modo que passa a produzir códigos próprios que interagem também com códigos sobre estes corpos que não foram produzidos por eles mesmos.

Assim, o autorretrato de artistas mulheres possui uma dimensão e relevância poética e política. Ele cria o lugar para que suas histórias, suas experiências, suas perspectivas e as pessoas em si possam existir.

O autorretrato, enquanto trabalho artístico, depoimento, discurso, registro, documento - independente da linguagem - gera um lugar na História, de modo independente, que não se submete a instâncias oficiais. Muito pelo contrário, aparece muitas vezes como uma crítica à História oficial e reivindica seu lugar nela negado.

O autorretrato pode ser então um instrumento artístico, social e político que cria quebras, intervalos, pausas e deixas nos discursos hegemônicos, servindo a diversos grupos não-hegemônicos, tais como mulheres, negros, indígenas e não heteronormativos.

Dentro deste recorte, pensando nos autorretratos, foram referências relevantes na pesquisa os trabalhos das artistas Maya Deren e Ana Medieta, da escritora Carolina Maria de Jesus, o diário de Frida Kahlo e 
as estatuetas de Vênus.

Maya Deren (1917-1961)

Nascida Eleanora Derenkowsky, na Ucrânia, em 1917, a cineasta adotou o nome de Maya Deren, que foi retirado de um livro de mitologia. Foi poetiza e dançarina, mas foi no cinema que encontrou a melhor maneira de expressar suas ideias. Desenvolveu praticamente toda sua carreira nos Estados Unidos, onde ficou conhecida como precursora do cinema experimental e, mais recentemente, como precursora da videodança. Deren foi secretária da bailarina e coreógrafa afro-americana Katherine Dunham (1909-2006), com quem adquiriu o interesse pela antropologia ao realizar pesquisas sobre danças africanas. Após algumas viagens ao Haiti, Deren produziu e dirigiu um documentário sobre a dança vodu do Haiti: The Divine Horsemen: the living gods of Haiti (1947-1951). Sua intenção inicial era captar imagens para um filme em que as usaria juntamente com outras danças. No entanto, ao se deparar com as tradições vodu, percebeu que não poderia separar tais danças de sua mitologia própria.

Durante sua estadia no Haiti, Deren acabou por manifestar entidades vodus e foi iniciada.

...eles [haitianos] logo ficaram convencidos de que eu não era exatamente uma estrangeira, mas uma filha pródiga nativa que finalmente retornara.

(DEREN, 1970, p.8. Tradução minha).

Seu livro sobre o vodu é fruto da abertura e do acesso que Maya Deren teve sobre as práticas vodu como iniciada. Sua publicação foi insti- 
gada pelo antropólogo Joseph Campbell, após perceber que Deren podia contribuir com muitas informações que os antropólogos profissionais não poderiam, pois, segundo o provérbio haitiano, quando o antropólogo chega, os deuses se despedem (DEREN, 1970, p.x. Tradução minha).

A experiência estética dos filmes de Maya Deren parece mostrar que a cineasta traz experiências corporais desse universo espiritual, uma vez que parece reproduzir no cinema as sensações de incorporações, remeter a símbolos sagrados e dar lugar privilegiado à dança - tida como uma manifestação sagrada nessas tradições espirituais. Dentre os elementos que remetem a esse universo destacam-se o uso do slow motion, da dilatação do tempo, efeitos que produzem a sensação de não estar no chão, dos voos, e de giros.

Ao comentar sobre o uso que faz do slow motion, Deren afirma que compreende este recurso como um microscópio do tempo, que permite ver as transformações, ver o imperceptível. É um instrumento de descoberta, mais do que de criatividade, ainda assim um elemento válido para a criação de um filme baseado nas propriedades singulares do meio. (DEREN, 2005, p.120-121). Para ela, o movimento reverso produziria uma volta no tempo, mas não no espaço.

A ação criativa no filme, então, toma lugar na dimensão do tempo; e por esse motivo que a imagem em movimento, apesar de composto de imagens espaciais, é primordialmente uma forma de tempo.

(DEREN, 2005 p.124. Tradução minha)

Maya Deren não conseguia definir bem a natureza de seu trabalho, 
mas o via como uma exploração do meio fílmico. Ao se perguntar por que fazia filmes, entendeu que era o mesmo que motivava qualquer artista ou escritor: a convicção de que seu meio tem potencial infinito de transmitir as suas particulares percepções da vida. Via a própria linguagem cinematográfica como um poder mágico, uma vez que permite a manipulação do tempo e do espaço; um meio através do qual se poderia projetar, em termos reais, realidades interiores que as pessoas verdadeiramente viviam. (DEREN, 2005 p. 203-205)

Seus filmes são, no entanto, comumente enquadrados como surrealistas. Deren discorda desta colocação, afirmando que essa seria um interpretação superficial, e que seus filmes tratariam mais bem de um método, que não é o mesmo do surrealista. (DEREN, 2005, p.227-228).

Deren era muitas vezes a protagonista de seus filmes. $\mathrm{O}$ uso de seu próprio corpo e sua própria imagem no cinema - até mesmo duplicada ou triplicada - a aproximam da performance e da videoperformance na contemporaneidade. Deren também tinha consciência de sua importância enquanto cineasta diante da falta de mulheres neste ramo.

Seus escritos são porta de entrada para compreender a preciosidade de seus filmes e de sua pesquisa, nos quais ela desenvolve e compartiIha seus pensamentos e reflexões, tratando principalmente da linguagem cinematográfica.

No livro Essention Deren: Collected Writings on Film (2005), é instigante a maneira fluída e honesta com a que ela transita entre assuntos como bruxaria, espíritos e a linguagem do cinema. Seu livro sobre o vodu traz informações que surgem de experiências pessoais, mas que dizem respeito a uma realidade maior, coletiva, pouco disseminada, principalmente no período em que foi escrito. 
Ana Mendieta saiu de Cuba para os Estados Unidos durante a Operação Peter Pan - quando crianças entre 6 e 16 anos, fugindo do governo de Fidel Castro, conseguiram visto de entrada como estudantes para os EUA. A mudança a fez perceber a si mesma como mulher "de cor", não branca, já que sofria constantes agressões sendo chamada pejorativamente de "negra", "puta". Sua consciência identitária somada ao espaço natural abundante fizeram do México sua terceira casa.

A artista era militante feminista atuante e via seu trabalho como uma maneira de defender aqueles que ocupam as margens da sociedade. Mendieta fez performance, realizando vídeos e fotografias. Seu trabalho envolve uma relação direta com a natureza; traz referências da Santería, religião semelhante ao Candomblé no Brasil; do ritual; trata de gênero; de feminismo e de sua latinidade. A morte e a presença pela ausência também são assuntos relevantes no trabalho da artista.

Alguns defendem que sua morte tenha sido suicídio, outros, um assassinato pelo marido, o artista Carl Andre, que a teria atirado do $34^{\circ}$ andar após uma discussão. 
Nasceu em Minas Gerais. Afro-mineira, de uma cultura afro-católica, teve em sua infância uma vida cultural fervilhante. Seu avô era rezador da manifestação Nossa Senhora do Rosário e era ex-escravo.

A artista era escritora, poetiza, compositora, escreveu também músicas e peças teatrais. Se auto definia como preta. Ficou conhecida pela publicação de seu livro Quarto de despejo: diário de uma favelada (1960). Menos conhecido é seu livro Provérbios (1963), que Carolina publicou com seu próprio dinheiro.

O provérbio é uma linguagem especial, uma espécie de ideograma, uma sabedoria da comunidade.

Segundo o pesquisador especialista em cultura africana Kimbwandende Kia Bunseki Fu-Kiau (citado numa palestra pela historiadora Elena Pájaro Peres):

O provérbio esta entre as mais importantes fontes de explicação do ser africano e de seu pensamento. Em debates, em cerimonias em julgamentos, na alegria, como também na miséria, provérbios são geralmente usados para reprimir para criticar... é uma linguagem especial. (FU-KIAU apud PERES)

Segundo o historiador Lawrence W. Levine (1977), pesquisador do multicuturalismo e da cultura afro-americana, as artes expressivas e as crenças sagradas eram mais do que estratégias; eram instrumentos de vida, de sanidade, de saúde e de respeito próprio. Preservavam os 
escravos de uma escravidão espiritual. Criavam um mundo à parte, livre do controle dos senhores.

Em Provérbios, Carolina manifesta uma série de valores, que ainda que se possa inferir como sendo pessoais, também ressoam no coletivo, uma vez que trata de questões sociais como a riqueza, a pobreza e seu lugar como mulher negra favelada na sociedade.

A artista não reproduz provérbios a partir de uma religião, mas sim a partir de suas próprias experiências. Traz o provérbio como sabedoria e lição para saber viver. Trata Deus como o superior, aquele que dá tudo gratuitamente, enquanto que os homens vendem. Assim ela aproxima o espiritual do social, e o governo, da arte. Faz uma crítica ao academicismo versus o valor humano, ao falar dos portadores de diplomas, cujas ações não o comprovam. Fala do preconceito, da importância de se construir escolas, da honestidade e de confiar na cultura e não no dinheiro. Fala do poder do amor. 
Frida Kahlo nasceu em 6 de julho de 1907 na Cidade do México.

Seu pai era Guillermo Kahlo, de descendência alemã e sua mãe, Matilde Gonzalez y Calderón, de origem indígena e espanhola.

Aos seis anos, Frida contraiu poliomielite, a primeira de uma série de doenças, acidentes, lesões e operações que sofreu ao longo da vida. A poliomielite deixou uma lesão no seu pé direito. Foi depois desse incidente que Frida passou a usar calças e saias longas.

Em 1925 sofreu um grave acidente. Um bonde, no qual viajava, chocou-se com um trem. O pára-choque de um dos veículos perfurou-lhe as costas, causando uma fratura pélvica e hemorragia. Frida ficou muitos meses entre a vida e a morte no hospital, tendo que operar diversas partes e reconstruir por inteiro seu corpo que estava todo perfurado. Tal acidente a obrigou a usar coletes ortopédicos de diversos materiais.

Foi durante sua convalescência que ela começou a pintar. Posteriormente, entrou no Partido Comunista Mexicano.

André Breton chegou a qualificar sua obra como surrealista. Mas a artista negou, dizendo que nunca havia pintado sonhos, mas sim sua própria realidade.

Ainda que Frida Kahlo seja reconhecida como um ícone feminista e da luta revolucionária comunista, o trabalho de Frida que foi objeto de interesse desta pesquisa foi seu diário.

Frida possui inúmeros retratos de si mesma. Em suas pinturas traz sua imagem e sua história, a cultura tradicional indígena mexicana e também sua luta pela revolução comunista. Em seu diário, ela fala da preocu- 
pação de que seu trabalho seja útil ao movimento comunista, trazendo a dimensão da arte como atuação politica e social. Essa atuação no entanto não aparece desconectada de suas sensações, seus sentimentos, seus afetos e seu trabalho artístico. Através de seu diário, é possível acessar a construção de seu próprio repertório, a relação que faz entre cores, palavras, sentimentos, comidas.

Ao encontrar o escrito "XOCOLATL", deparei-me com a escolha da artista que se revela um índice cultural, afetivo e identitário, o que leva a lembrar que numa escrita íntima, mais próxima da experiência, a forma como se escreve é já em si um dado relevante.

A maneira como Frida entende sua atuação no movimento revolucionário comunista torna seu corpo, um corpo coletivo, uma vez que relaciona soviéticos, chineses, checoslovacos, polacos, indígenas mexicanos e negros como compartilhadores de seu sangue, que sofrem as mesmas opressões de exploração, dominação e preconceito dentro de uma esfera política, social e econômica hegemônica. A artista fala também da afinidade e afetividade pelos zapatistas.

... Integrados no sangue em minha própria pessoa.

(...)

Mexicanos e negros estão no momento subjulgados por países capitalistas.

(KAHLO, 1995)

Em seu diário, Frida conta o processo artístico de alguns trabalhos, mas ela também coloca suas enfermidades, seu corpo como um aprisionamento. $O$ autorretrato e a escrita de si se configuram então como um 
exercício de liberdade.

Vênus do Paleolítico

A arte rupestre é de interesse da pesquisa por ser uma arte potencialmente mágica, e por trazer imagens que não se sabe ao certo se eram representações de acontecimentos passados ou de algo que se desejava que acontecesse. É também uma arte anterior à dominação colonial.

A gama de estatuetas Vênus do Paleolítico é muito ampla, mais que a arte rupestre.

São estatuetas encontradas em países como França, Inglaterra, Rússia, Itália, entre outros, que não retratam necessariamente as deusas Vênus, mas que são registros de atividades locais. São quase 250 estatuetas Vênus conhecidas até então.

O termo "Vênus" foi usado pela primeira vez em meados do século XIX pelo Marquês de Vibraye, que descobriu uma importante estatueta de marfim e a nomeou de Vênus Impudica, em oposição à Vênus Pudica, escultura helenística que retrata Afrodite cobrindo o púbis nua com a mão direita.

As características típicas de uma Vênus do Paleolítico - seios fartos, ventre grande, nádegas gordas, pés e cabeça muitas vezes ausentes - fizeram com que pesquisadores acreditassem que estas estatuetas estivessem relacionadas à fertilidade, fartura, abundância, religiosidade e também à sexualidade. Assim, consagrou-se a ideia da Vênus como uma exacerbação do que se crê como feminino, de sua sexualidade, da "grande deusa mãe".

No entanto, o significado cultural original e sua finalidade não são conhecidos. Cogita-se que tenham servido a uma função ritual ou simbó- 
lica. Há diversas interpretações especulativas sobre seu uso e significado.

$\mathrm{O}$ alvo de interesse desta pesquisa é um dado quase sempre ignorado. Um grande número de Vênus não possuem cabeça, o que levou pesquisadores a acreditarem que poderia tratar-se de autorretratos de mulheres que nunca haviam utilizado espelhos. Alguns pesquisadores reivindicam ainda que dentre estas estatuetas, estaria a primeira representação humana já feita - a Vênus de Tan-Tan. Assim, a primeira representação humana seria uma mulher feita por uma artista mulher.

Enquanto é possível encontrar diversos discursos patológicos, particularizantes que subestimam e inferiorizam a autobiografia e autorretrato das mulheres, encontra-se aqui um exemplo potente e artístico deste ato de retratar-se. 



\section{Ancestralidade, Espiritualidade e Cura}

No percurso da pesquisa, deparei-me com algumas relações entre mulheres, ancestralidade, espíritos, ritual, doença e cura. 
Durante a investigação encontrei o trabalho de Gabriela Serfaty, que conheci em uma palestra no centro cultural Casa do Povo, no centro de São Paulo.

Em sua pesquisa, tomando como foco o corpo das mulheres, o corpo é entendido como para além do biológico, um corpo como sintoma cultural, um corpo agente e que é alvo de tentativa de controle, entendendo que a histeria não é da natureza do feminino.

Para a minha pesquisa de mestrado, interessou-me a abordagem de Gabriela da histeria como um protesto que se dá através do corpo; um discurso que se dá a partir do corpo e pelo corpo, que reage e denuncia a repressão das mulheres na sociedade, um corpo que sempre foi feito para servir, ser dócil e se rebela.

Ela entende assim, a histeria como sendo mais um acontecimento do que uma metáfora. Entende esse corpo histérico, como uma textualidade que é do próprio corpo- é o próprio corpo produzindo texto. Corpo reprimido, silenciado, que sem palavras, produz gestos - um manifesto.

Gabriela chama assim a atenção para uma visão mais política e cultural do adoecimento, já que todos adoecem com a pele, com os órgãos - com o corpo.

A pesquisa de Gabriela traz ainda a questão sobre a representação do ato histérico. Em Salpêtrière - antigo asilo e hospital psiquiátrico para mulheres, localizado na França, atualmente funcionando como um centro hospitalar universitário - estiveram internadas cerca de 12.000 mulheres, histéricas e com outros diagnósticos, inclusive algumas que não tinham nenhum diagnóstico mas eram perseguidas politicamente. Jean Martin 
Charcot (1825- 193) cria um serviço de fotografia no hospital e, ao pesquisar os movimentos destas mulheres, passa a fabricar imagens sobre esses corpos. Charcot passa a representar o ato histérico dentro de um estúdio fotográfico, criando uma imagem da mulher histérica. A histeria virou assim um espetáculo, sendo possível então falar sobre uma estética da histeria. Georges Didi Huberman fala sobre essa criação da histeria através da fotografia em seu livro Invenção da histeria: Charcot e a iconografia fotográfica de Salpêtrière.

A pesquisa de Gabriela traz uma visão mais política sobre o corpo feminino, inclusive quando doente; aponta a fabricação desse imaginário do corpo feminino como potencialmente histérico; traz a relevância do repertório do corpo das mulheres, sua textualidade, e sua ação enquanto manifesto.

Assim, é possível compreender que as artistas mulheres ao produzirem trabalhos artísticos com seu próprio corpo, estão em constante dialogo e negociação com este imaginário, o qual artistas feministas vêm se empenhando em desconstruir. 
O assunto apareceu, anos atrás, quando eu estava indo assistir a um filme numa mostra. Eu não havia escolhido o filme, apenas o tema da mostra havia me chamado a atenção e me sentei ali, num horário em que não tinha compromisso para assistir o que estava passando.

Quando cheguei, já havia passado boa parte do filme. O que passou foi o documentário Tarantula (La Taranta) (1962), do diretor Gianfranco Mingozzi, sob os conselhos de Ernesto de Martino e comentado por Salvatore Quasimodo, com música de Diego Carpitella. Este foi considerado o primeiro filme sobre o Tarantismo, filmado em Satento - Itália.

Tempos antes, eu havia tido um sonho com meu mestre Pinguim, em que ele batia tambor, tocando e eu começava a subir pelas paredes com outra pessoa em luta. Eu era uma aranha. Mas este sonho trazia muita energia, muita força, muita inteligência, estratégia e luta.

Assistindo ao filme, veio-me exatamente esse sonho e chorei. Assim, o interesse pelo filme surgiu como uma identificação pessoal pelo diálogo que tinha com meu sonho e também com a pesquisa. A partir dai procurei o filme para assistir novamente e busquei algumas informações sobre ele.

O documentário traz registros do ritual Taranta, o qual tinha como objetivo libertar as mulheres acometidas pelo Tarantismo, que supostamente teriam sido picadas por uma tarântula, o que causava espasmos e contorções

$\mathrm{Na}$ Taranta eram chamados músicos que tocavam e as mulheres acometidas pelo tarantismo dançavam compulsivamente. Esta foi inclusive a origem da manifestação popular Tarantela. Nas palavras de Ernesto 
de Martino:

A dança realizada durante a cura é a tarantela, que é a dança do pequeno taranta. O tarantato, aquele que foi picado, dança a aranha que a picou e ao mesmo tempo a atropela e esmaga com o pé que dança: essa valência de identificação de luta é o caráter fundamental do tarantismo como cura. Quem dança se torna uma aranha: ele o imita, rasteja no chão ou anda de quatro, sobe, rola a tela, pula mas ao mesmo tempo se agita agonizantemente contra a aranha que a possui...

(Ernesto De Martino)

Tal ritual, envolto por uma espécie de estado alterado, acontecendo numa igreja, com música e dança, lembrou-me as festas públicas do Candomblé. Três tocadores, mulheres que dançam em círculo, transe, movimentos que parecem não se ter controle, mas ainda assim, uma dança. Haviam também imagens do santo São Paulo, protetor das vítimas. Para mim, era claro que se tratava de alguma espécie de estado espiritual alterado, algo semelhante ao que chamam vulgarmente de possessão.

Segundo informações que encontrei, tratava-se de uma doença semelhante ao que se convencionou chamar de histeria; o resultado de uma vida opressiva sofrida pelas mulheres - algo que acontece ainda hoje. 


\section{Curandeiras}

Durante o mestrado retomei uma pesquisa de iniciação científica que traz contribuições pertinentes a esta investigação.

No projeto Práticas curativas de curandeiras e benzedeiras versus práticas de padres no Brasil Colônia começo a analisar o contexto histórico entre os séculos XVI e XVIII no Brasil e a relação com as mulheres benzedeiras e curandeiras - que eram perseguidas - em comparação às praticas curativas dos padres, jesuítas e exorcistas - que tinham o aval da Igreja.

Durante esse período, assim como sua metrópole, o Brasil vivia um extremo atraso científico sob a dominação da Igreja. Havia uma grande escassez de médicos, as universidades estavam estagnadas e qualquer iniciativa cientifica ou cultural era considerada heresia. Acreditava-se que a doença era uma advertência divina, sendo a quantidade de pecados cometidos diretamente proporcional à quantidade e gravidade de doenças. Foi nesse contexto que surgiu um "conhecimento" sobre o funcionamento do corpo da mulher.

No período colonial, todo conhecimento médico existente sobre o corpo feminino dizia respeito à reprodução. A mulher era identificada pela madre, como chamavam o útero. O corpo feminino era considerado inferior e mais vulnerável às ações do Diabo, e subordinado à existência do masculino.

O desconhecimento anatômico, a ignorância fisiológica e as fantasias sobre o corpo feminino fizeram com que se criasse um discurso de desconfiança em relação à mulher, que era visto como um palco no qual Deus e o Diabo se digladiavam. Qualquer doença que acometesse 
a mulher era interpretada como um pecado cometido, como um sinal demoníaco ou feitiço diabólico.

Este corpo nebuloso, enquanto objeto de desconfiança encontrava-se numa ambiguidade: ainda que mapeado biologicamente e definido em suas limitações procriativas, à madre também eram atribuídos os poderes de cura e de morte. Acreditava-se que o sangue menstrual era capaz de enlouquecer e matar, bem como indicado para determinadas mazelas; o sêmen, somente em contato com o útero, também teria poderes curativos. (PRIORE, 2008, p. 102)

Exorcistas se utilizaram desta ideia para que tivessem cópula com mulheres enfermas, alegando que a cura estaria no próprio coito. Estes padres e exorcistas se utilizavam do poder da Igreja para abusar das muIheres. Em processos da Inquisição do Santo Oficio, eles mesmos admitiram não acreditar nos poderes médicos de suas práticas.

Estes fatores revelam possivelmente as origens das relações de inferiorização, demonização e patologização que se estabelecem no Brasil com as mulheres e seus corpos e também com as mulheres atuantes em práticas curativas como as de curandeiras e benzedeiras.

Estas relações e os discursos delas advindas permanecem nos dias atuais e podem ser identificadas em análises sobre os trabalhos de artistas mulheres e seus corpos.

A demonização de mulheres e indígenas não impossibilitou, no entanto, que jesuítas se beneficiassem dos conhecimentos destes e se tornassem importantes praticantes da medicina no Brasil. A Igreja procurava a todo custo provar que era a única detentora do poder de cura. 


\section{Grada Kilomba (1968)}

Ao tratar da descolonização durante uma conferência na imersão artística Afrotranscendence de 2016, a artista e professora universitária Grada Kilomba apontou a relevância de recontar nossa história, recontar o passado, dar nome às pessoas. O mais instigante foi sua colocação sobre a importância de contar ao nosso modo, com honra e dignidade, o que implica em mudança de termos; falar diretamente sem passar pelo norte (colonizadores); desincorporar a produção do conhecimento separado da biografia (tido como universal, objetivo, imparcial); pensar e fazer a performatização do conhecimento; produção de conhecimento com outros utensílios, formatos, vocabulários e então, produzir nossa própria história.

Kilomba aponta assim, a descolonização também no modo de fazer e não somente no conteúdo. Segundo ela, o colonialismo é um fantasma que tentamos passar. 
Percebo que, intuitivamente, acabei por construir um trabalho que evidencia as dimensões artísticas, poéticas e políticas sobre os corpos das mulheres, ainda que em estados tidos como doenças, o que marca minha preocupação em apontar a relevância da perspectiva com que são tratados estes corpos e, por consequência, suas vidas e seus trabalhos. Assim a perspectiva se revela um fator determinante na formação de discursos sobre estas pessoas, tendo como impulso inicial de investigação especificamente de artistas mulheres.

Este esforço almeja trazer uma singela contribuição para o âmbito da arte e da história da arte e para os trabalhos destas artistas e os estudos sobre eles, ao problematizar perspectivas que alimentam a continuidade e permanência destes discursos que são fruto de uma visão demonizadora e inferiorizadora das mulheres, que parecem ter se calcado, ao menos no Brasil, durante o período Colonial, quando da vinda dos portugueses e do processo de dominação, exploração e catequização. 



\section{Espectros e suas Materialidades}

Um dos interesses da pesquisa foi investigar as materialidades dos espíritos/espectros. Quais são os elementos que remetem a eles num trabalho artístico? Como? A partir de que referencial? Como identificá-los? 


\section{Aparato Comunicacional}

Erick Felinto, em seu livro A Imagem Espectral: Comunicação, Cinema e Fantasmagoria Tecnológica (2008), oferece uma série de referências literárias, tecnológicas e cinematográficas sobre os espectros. $\bigcirc$ autor conduz a questão partindo de elementos presentes em filmes, no qual sua principal referencia é o filme A Espinha do Diabo (2001) de Guillermo Del Toro. Sendo assim, cada capítulo, cada tópico destrinchado parte de frases da fala de um narrador invisível na abertura deste filme:

O que é um fantasma? Um evento terrível condenado a repetir-se infindavelmente. Um instante de dor, talvez. Algo morto que parece por momentos ainda vivo. Um sentimento suspenso no tempo, como uma fotografia borrada, como um inseto aprisionado no âmbar.

(FELINTO, 2008, p. 21). explorar.

Nesta fala estão todos os significados de fantasma que Felinto vai

Ainda que a idéia prevalente seja a do fantasma como entidade muda, muitos fantasmas são apenas audíveis e deixam rastros sonoros. A principal teoria de Felinto é de que os fantasmas seriam em si aparatos comunicacionais.

Conforme afirmam diferentes autores sobre o fantasma:

...fantasmas frequentemente não parecem ser muito mais que imagens em um etéreo gravador de vídeo que fica tocando sem cessar ad infinitum. 
(BAKER apud FELINTO, 2008, p.22)

... a mediação mecânica tornou-se [...] um veículo de presenças, uma forma salvífica viva com conexões vibracionais e telegráficas.

(SHMIDT apud FELINTO, 2008, p.23)

Dentre as principais referências sobre a relação entre aparatos comunicacionais e os fantasmas o autor cita os livros Haunted Media: Eletronic Presence from Telegraphy to Television (2000), de Jeffrey Sconce e o livro Thechnical Spirit Communication (1997), de Theo Locher e Maggy H. Fischbach .

Felinto apresenta alguns casos da utilização destes aparatos como meios de comunicação com o além. A médium Etta Wriedt usou o seu trompete falante para canalizar vozes dos mortos em suas sessões. $O$ mesmo aconteceu com o telefone que foi adaptado e renomeado psicophone. Sobre o imaginário fantasmagórico sobre o telefone, acredita-se que:

... a capacidade do telefone de tornar presente a voz descorporificada do ausente evocava um sentido de reverência tecnológica.

(SCHMIDT apud FELINTO, 2005, p.23)

Friedrich Jürgensen gravava sons dos pássaros e encontrou mensagens do além em suas gravações (FELINTO, 2008, p.82-83). Klaus Schreiber possuía dons mediúnicos e paranormais e comunicava-se por 
meio de aparatos como gravadores de fita (FELINTO, 2008, p.86). No Brasil, a escritora Hilda Hilst se dedicou a tentativas de contato com a amigos e familiares mortos através da gravação de fitas; e mesmo o caso como a lenda de que a famosa Xuxa, a rainha dos baixinhos teria gravado mensagens demoníacas em seus discos e fitas e que seriam reveladas ouvindo-os de trás para frente ganharam repercussão. 


\section{Espelho}

Outro elemento relacionado ao fantasma é o espelho. $O$ espelho permite gerar um reflexo, uma duplicação, um espectro de si.

Tal ideia idéia permitia imaginar o Doppelgänger como um fantasma vindo de outra dimensão temporal, um fantasma perturbador de ordem do tempo, a atormentar o sujeito de quem ele é imagem espectral. (FELINTO, 2008, p.32)

Felinto dedica um capítulo inteiro para falar da questão do duplo, tamanha é sua relevância e recorrência em relação ao fantasma. Doppelgänger é um termo de origem alemã que significa o duplo. O duplo está frequentemente associada a premonições nefastas e à sombra.

Afim de ilustrar essa relação entre o espelho, o duplo e o fantasma, o autor cita um conto de Edgar Allan Poe em que o personagem William Wilson surpreende-se com uma cena em que parecia uma imagem refletida no espelho, e no entanto não era um espelho, mas ele mesmo - nosso lado obscuro, nossa condição mortal; e o filme $O$ estudante de Praga em que o personagem Balduim faz um pacto sinistro com um mago sem saber que seu pagamento seria seu reflexo, o qual saiu de um espelho e passou a vagar pelo mundo.

Freud vai conceituar o termo Das Unheimliche: estranho, sinistro, ou inquietante estranheza, mas que não se trata do oposto de heimliche (familiar, conhecido), mas sim de estranho quanto maior for a proximidade com o conhecido e familiar. 
E na origem a figura do duplo aparecia como benfazeja, como uma garantia contra a morte e a finitude humana. E assim ela é percebida no âmbito do narcisismo primário. Contudo, superada essa etapa, o duplo passa a ter o papel inverso: "depois de haver sido uma garantia da imortalidade, transforma-se em um estranho anunciador da morte" (Freud, 1976, p.294). Nesse sentido, nenhuma espécie de duplo parecerá mais apropriado que o fantasma. De fato Freud observa que os espíritos e fantasmas exemplificam com perfeição o termo do unheimliche.

(FELINTO, 2008, p.36-37).

O duplo leva diretamente a um efeito de especularidade. Até mesmo etimologicamente os termos espelho, espetáculo, espectro e espectador estão ligados. O espelho é uma abertura que conduz a outras realidades, muito além da verdade ou da mentira. (FELINTO, 2008 p.40)

O espelho estaria ainda relacionado a teorias sobre a Quarta Dimensão. Marcel Duchamp (1887-1955), em suas pesquisas sobre a quarta dimensão, opta por uma ilusão visual baseada em espelhos e imagens virtuais, o que o levaria a realizar sua obra O Grande Vidro (1915-1923).

... a ciência, a tecnologia e a geometria com quatro dimensões, que foram as verdadeiras fontes para a inspiração, foram suplantadas pelas descobertas como a da teoria da relatividade e a da física quântica.

(LYRA, 2008, p.96-98) 


\section{Tempo}

Segundo Felinto, a principal característica do fantasma é em relação ao tempo. O fantasma é um ser que não obedece à regra geral, que mesmo depois de morto, parece por vezes vivo, que retorna, que atravessa o tempo. O fantasma é assim uma entidade anacrônica, deslocada em relação ao fluxo do tempo.

Nem passado nem presente, o fantasma é esse instante de ambiguidade suprema, indecidível, irrepresentável, indeterminado.

(...)

...é bastante curioso que uma das mais ousadas "teorias" a respeito das aparições de fantasmas invoque justamente a ideia de "deslocamentos de tempo". Segundo essa essa teoria, certas visões teriam origem não em alguma entidade que se manifesta no tempo presente, mas em uma espécie de salto no tempo, no qual o observador se torna capaz de vislumbrar seres, objetos e paisagem de outras eras.

(FELINTO, 2008, p.50-51) 


\section{Transparência e Sobreimpressão}

A sobreimpressão produz umas figuras imateriais e translúcidas que estranhamente se parecem as representações arquetípicas das aparições ou dos ressuscitados, figuras as quais haviam se popularizado no Romantismo.

(CHÉROUX, p.193-194)

Clément Cheroux, indica que já existiriam desde a Idade Média aparições revestidos de sudários transparentes e que este tipo de representação é sem dúvida característico do Romantismo.

A transparência e a sobreimpressão são comumente relacionadas ao fantasma no cinema. A iconografia do fantasma enquanto transparência teria sua origem no Romatismo, principalmente no gótico. 


\section{Fotografia Espírita}

Clément Chéroux,historiador da arte com especialidade em fotografia, trata da fotografia espírita - que segundo ele se dá em meio a uma convicção e por outro lado é cercada por charlatanismo. Chéroux conta principalmente da historia do fotógrafo Ėdouard Isidore Buguet, mas também da fotografia como meio de capturar e provar a existência dos espíritos pelos convictos espíritas, que baseavam-se no caráter indicial da fotografia, na crença em sua objetividade da realidade, como é o caso de Pierre Gaëtan Leymarie.

Esta estranha analogia entre a forma fotográfica produzida pela sobreimpressão e o imaginário popular sobre aparições recebeu na época das interpretações distintas. A maioria dos observadores atribuiam a aparição inesperada destas imagens fantasmáticas ao efeito combinado de azar com erros técnicos e não as consideravam mais do que meros acidentes. Mas à medidaem que o espiritismo começou a se dsenvolver, desde o final da década de 1840 nos Estados Unidos e os primeiros anos da década seguinte na Europa, alguns de seus adeptos começaram a considerar que os fantasmas da fotografia eram verdadeiros fantasmas.

(...)

Conforme um processo frequente na história da fotografia, o acidente não tardou em ter uma aplicação. Explorando a imagem aparecida, entre a forma fotográfica produzida pela sobreimpressão e o imaginário relativo aos fantasmas e apa- 
rições, tal como se inscrevia no momento na imaginação coletiva, a partir da década de 1850 alguns fotógrafos começaram a produzir fotografias de espíritos, já não por acidente, mas sim de forma deliberada.

(CHÉROUX, p.194. Tradução minha.)

Nesse contexto, acreditava-se que a parição de espíritos na fotografia eram a impressão de imagens mentais. Os espíritas pediam para que se pensasse em alguém morto para se manifestar na fotografia. É importante ressaltar que nesse momento, algumas aparições que inicialmente ocorriam como incidentes durante o processo fotográfico, passaram a ser produzidas intencionalmente pelos fotógrafos, chegando mesmo a se constituir como um "gênero" de diversão. Simultaneamente, havia uma busca de espíritas convictos que desejavam através da fotografia encontrar provas científicas da existência dos espíritos, como é o acaso de Leymarie, bem como comunicarem-se com eles, o que facilitou que charlatões como Buguet, pudessem se aproveitar de sua fé, produzindo fantasmas em laboratório àqueles que desejavam comunicar-se com entes queridos no além. 
O "fotoscópio" era uma espécie de lanterna mágica usada para produzir fantasmas no espetáculo de Etienne-Gaspard Robertson, denominado Fantasmagoria (1802). Tom Gunning , professor de cinema no Departamento de História da Arte da Universidade de Chicago - vai falar de como Robertson usava de uma maneira específica a lanterna mágica, não projetada sobre a parede, mas diretamente sobre uma tela transparente que refletia diretamente no espectador, simultaneamente mostrando-lhes os fantasmas e os cegando. Apesar de Robertson anunciar o espetáculo como uma prova de que os fantasmas não existem, assumindo um lugar da racionalidade - no entendimento dos fantasmas enquanto ficção produzida por máquinas - Gunning vai defender que toda a maneira como o espetáculo funcionava, induzia, ou ao menos confundia o espectador, desestabilizando-o quanto às suas sensações.

Gunning fala sobre como um espetáculo que a princípio deveria ser uma revelação científica (havia também demonstrações do galvanismo numa das primeiras salas percorridas durantes o espetáculo) e afirmava que os espíritos não existiam, podia ainda assim fazer crer, ou ao menos duvidar da existência de fantasmas. Ele coloca que a questão estava principalmente na produção de perturbação dos sentidos: as demonstrações do galvanismo, as vozes e sons, o local, a maneira como era conduzido o espetáculo e até mesmo as figuras fantasmas históricas que apareciam como Marat (1743-1793) e Robespierre (1758-1794) traziam a tona o clima de terror.

O autor aponta criticamente a persistência dessa ideia de racionalidade em oposição ao mundo dos sentidos, colocando que Robertson 
usava a lanterna mágica de uma maneira diferente, lançando a luz diretamente sobre o espectador, causando um desnorteamento, somados aos outros artifícios como sons e fumaça. 
Sudário e o Negativo Fotográfico

O Sudário - o pano que teria recoberto o rosto de Cristo, e deixado por contato a marca de sua face - ainda que sendo um importante objeto de culto, foi durante um tempo objeto de dúvidas. Não era possível reconhecer naquele pano um rosto. Foi somente com a contratação de um fotógrafo, que durante a revelação do filme, foi possível visualizar o rosto definido no negativo fotográfico. Ou seja, a imagem foi revelada, reconhecível através do negativo fotográfico (DUBOIS, 2009, p.224). 


\section{Teoria dos Espectros - Honoré de Balzac}

Segundo a "Teoria dos Espectros" de Balzac - que tem-se notícias através de escritos do fotógrafo Félix Nadar (1820.1910) - as pessoas seriam constituídas de camadas infinitas de espectros (como uma cebola), que seriam transferidas para a fotografia, quando fotografadas, podendo assim desaparecer. Por isso, Balzac tinha medo e evitava ser fotografado pelo amigo. 
A partir do interesse nas sutilezas, nos acontecimentos pequenos, mínimos, mas de natureza do imperceptível e invisível, encontrei as notas Inframince do artista Marcel Duchamp (1887-1968) escritas em torno de 1935 e publicadas posteriormente por Paulo Matisse que pareciam pertinentes à pesquisa.

Inframince trata da invisibilidade e da sensorialidade. Trata de fazer obras com o quase imperceptível ou com o invisível - fumaça, respiração, hálito .

Tal entendimento parecia caber perfeitamente no que havia encontrado sobre as possíveis materialidades dos espectros em sua característica temporal: efêmera, mutável, indeterminada.

De maneira análoga, cheguei até o infrassom, que é uma frequência sonora abaixo do nível audível pelo ser humano. Alguns animais são capazes de produzir e detectar infrassons. Eles também são produzidos por ventos, tempestades e terremotos.

Algumas pesquisas científicas já relacionaram a presença de infrassons à locais mal assombrados. Descobriu-se que, apesar de não serem identificados por seres humanos, os infrassons são capazes de provocar sensações incomuns e alteração psicológica, como estados de medo, ansiedade e depressão. Acredita-se que o vento em locais abandonados se propaga de tal maneira que produz infrassons, resultando em sensações incomuns, arrepios e medo, que as pessoas relacionam com a presença de fantasmas, assombrações e espíritos.

Outras pesquisas também investigam a potência do infrassom para ser utilizada como arma. 


\section{Fantasmata}

Durante a pesquisa deparei-me com a fantasmata que, segundo o tratado do coreógrafo Domenico Piacenzo (1390-1470), é elemento central na dança.

Em meados do século XV, o famoso coreógrafo Domenico Piacenza mestre de dança da corte Sforza de Milão, e da corte dos Gonzaga de Ferrara - escreveu o tratado Sobre a arte de bailar e dançar. Nele, Domenico elenca seis elementos fundamentais da dança: medida, memória, agilidade, maneira, medida do terreno e fantasmata. Domenico define esse último:

Digo a ti, que quer apreender o ofício, é necessário dançar por fantasmata, e nota que fantasmata é uma presteza corporal, que é movida com o entendimento da medida [...] parando de vez em quando como se tivesse visto a cabeça da medusa, como diz o poeta, isto é, uma vez feito o movimento, sê todo de pedra naquele instante, e no instante seguinte cria asas como falcão que tenha sido movido pela fome, segundo a regra acima, isto é, agindo com medida, memoria, maneira com medida de terreno e espaço.

(PIACENZA apud AGAMBEN, 2012, p. 23-24)

Partindo da relação entre memória e imagem (fantasma) como uma afecção da sensação ou do pensamento, Agamben afirma que para Domenico a dança é:

...essencialmente uma operação conduzida sobre a memoria, 
uma composição dos fantasmas [das imagens] em uma série temporalmente e espacialmente ordenada. O verdadeiro lugar do dançarino não está no corpo e em seu movimento, mas na imagem como "cabeça de medusa", como pausa não imóvel, mas carregada, ao mesmo tempo, de memoria e de energia dinâmica. Porém isso significa que a essência da dança não é mais o movimento - é o tempo.

(AGAMBEN, 2012, p. 25)

A relação entre corpo, imagem, dança, tempo e espectro discutidas por Domenico e Agamben coincide com minha investigação. Tal relação foi desenvolvida de um modo teórico- prático na pesquisa, o que possibilitou um estiramento e reelaboração destas ideias. 


\section{Yowa - Círculo Kongo}

Em Flash of the Spirit: Arte e Filosofia Africana e Afro-Americana (2011), escrito pelo pesquisador Robert Farris Thompson - livro que posteriormente se tornou objeto cultuado dentro do vodu - encontrei uma referência ao Círculo do Kongo, chamado de Yowa.

Segundo Thompson:

Um garfo na estrada (ou mesmo um ramo bifurcado) pode aludir a esse símbolo crucialmente importante da passagem e da comunicação entre os mundos. A "virada na trilha", isto é, a encruzilhada, permanece um conceito indelével do mundo atlântico Kongo como o ponto de cruzamento ou de intenção entre os ancestrais e os vivos.

(THOMPSON, 2011, p.113)

A marca Yowa pode ser encontrada no Brasil, por exemplo, nas determinações dos horários para cada atividade ritual específica dentro das religiões de matriz africana e em suas manifestações culturais. Ela também parece marcar, nesse cruzamento entre os ancestrais e os vivos, entre o tempo de agora e um não tempo infinito, os movimentos em círculo em sentido anti-horário na dança que podem ser vistos, por exemplo, em trabalhos públicos do Candomblé - um tempo dos vivos em retorno ao tempo dos ancestrais, e dos ancestrais a caminho do tempo dos vivos. 
Fotografia Kirlian

A fotografia Kirlian reside entre uma concepção espiritual, mística e científica. Alguns alegam que esta fotografia seja capaz de captar uma espécie de "aura" das coisas, enquanto outras pesquisas oferecem uma explicação física, mas que exclui a concepção espiritual. 


\section{Matéria Escura}

Durante uma tentativa de mensurar toda a matéria do universo, cientistas se depararam com cálculos que pareciam incoerentes. Descobriu-se que cerca de $26 \%$ da matéria do universo não interage com a luz, não é visível, mas interage garvitacionalmente com a matéria conhecida.

O conhecimento da matéria escura, que junto com a energia escura constitui $95,1 \%$ do universo, abre precedentes para uma pesquisa relevante sobre o invisível, que forma grande parte do universo. As pesquisas atuais investigam principalmente do que é constituída a matéria escura e seu comportamento. 
Partindo de meu trabalho artístico, a pesquisa teórico-prática do mestrado se desenvolveu em diálogo com artistas, autores, assuntos e ideias investigados e que foram aqui apontados. 

Referências Bibliográficas e Fílmicas 
Referências Bibliográficas

AFONSO, Marta Jerónimo Miranda. O corpo feminino na ilustração científica: uma reflexão visual em torno de convenções e padrões de representação. Dissertação de Mestrado. Matosinhos: Escola Superior de Arte e Disign de Matosinhos, 2014.

AGAMBEN, Giorgio. Ninfas. São Paulo: Hedra. 2012.

BERNSTEIN, Ana. "A performance solo e o sujeito autobiográfico". Revista Sala Preta. v.1, 2001, p.91-103.

BLOCKER, Jame. Where is Ana Mendieta? Identity, performativity and Exile. London: Duke University Press, 1999.

BORGES, Antonio Newton; RODRIGUES, Clóves Gonçalves. Introdução à Física Acústica. São Paulo: LF Editorial, 2017.

BUTLER, Judith. "Atos perfomativos e constituição de gênero. Um ensaio sobre fenomenologia e teoria feminista". In: MACEDO, Ana Gabriela; RAYNER, Francesca (Org.). Gênero, cultura visual e perfomance: antologia crítica. Minho: Universidade do Minho/Húmus, 2011.

BUTLER, Judith. Cuerpos que importan: sobre los límites materiales y discursivosdel "sexo". Buenos Aires, Paidós, 2008.

BUTLER, Judith. "Problema de los géneros, teoría feminista y discurso psicoanalítico". In: NICHOLSON, J. Linda (Org.). Feminismo/Posmodernismo. Buenos Aires: Feminaria Editora, 1992. p. 75-95.

BUTLER, Judith. Problemas de gênero: Feminismo e subversão da identidade. Rio 
de Janeiro, Civilização Brasileira, 2003.

CALAINHO, Daniela Buono. "Jesuítas e medicina no Brasil colonial". Tempo. 2005, n 19, pp. 61-75.

CHÉROUX, Clément. "El caso de la fotografía espiritista y la imagen espectral: entre la diversión y la convicción". Tradução de Pilar Vázquez. [Disponível em: https://reacto.webs.ull.es/pdfs/n4/clement_cheroux.pdf]. Acesso em 11 de maio de 2016.

CHÉROUX, Clément; FISCHER, Andreas. APRAXINE, Pierre; CAMGUILHEM, Denis. SCHMIT, Sophie. Le Troisième Oeil: la photographie et l'occulte. Paris: Gallimard, 2004.

COHEN, Renato. Performance como linguagem: criação de um tempo-espaço de experimentação. São Paulo Editora Perspectiva, 2002.

DANTO, Arthur C. "Darkness Visible". The Nation, outubro n 15, 2004. [Disponível em: http://www.thenation.com/article/darkness-visible-0/]. Acesso em 17 de junho de 2015.

DEREN, Maya. Divine Horsemen: vodoo gods of Haiti. New York: Chelsea House Publishers, 1970.

DEREN, Maya. MCPHERSON, Bruce Rice (org). Essential Deren: Collected Writings on Film. New York: McPherson, 2005.

DUBOIS, Philippe. O ato fotográfico. $12^{\mathrm{a}}$ ed. Campinas: Papirus Editora, 2009.

FELINTO, Erick. A Imagem Espectral: Comunicação, Cinema e Fantasmagoria 
Tecnológica. São Paulo: Ateliê Editorial, 2008.

FERREIRA, Glória; CONTRIM, Cecília (org.). Escritos de artista anos 60/70. Rio de Janeiro: Zahar, 2006.

FRANCISQUETTI, Paula Patrícia Serra Nabas. Ana Mendieta: Atravessamentos em um coração desprotegido. São Paulo: Programa de Pós-Graduação Interunidades em Estética e História da Arte - Universidade de São Paulo, 2009.

FU- KIAU, Kimbwandende Kia Bunseki. African Cosmology of the Banter- Kongo: tying the spiritual knot, principles of live \& living. Canada: Athelia Henrietta Press, 1980.

FUSCO, Coco (org). Corpus Delecti: Performance Art of the Americas. London and New York: Routledge, 2000.

GISI, Juliana. 60/70: as fotografias, os artistas e seus discursos. Curitiba: Juliana Gisi Martins de Almeida, 2015.

GUMBRECHT, Hans Ulrich. Produção de Presença: o que o sentido não consegue transmitir. Rio de Janeiro: Editora Contraponto, 2010.

GLUSBERG, Jorge. A arte da performance. São Paulo: Editora Perspectiva, 1987. London: Thames \& Rudson, 2001.

GUNNING, Tom. "The Illusions Past and Future: The Phantasmagoria and its Especters". [Disponível em: http://www.mediaarthistory.org/refresh/Programmatic\%20key\%20texts/pdfs/Gunning.pdf]. Acesso em 10 de junho de 2016.

JESUS, Carolina Maria de. Provérbios. São Paulo: s/editora, 1963. 
KAHLO, Frida. El diario de Frida Kahlo: un autorretrato íntimo. Ciudad del México: la vaca independiente, 1995.

KIRCHER, Athanasius. Magnes sive De Arte Magnetica. Opus tripartitum. Rome: 1641. Exhibition up to November 29, 2017 "The dance" at National Library of Naples

LEVINE, Lawrence W. Black Culture and Black Consciousness: Afro-american folk thought from slavery to freedom. New York : Oxford University Press, 1977.

LIPPARD, Lucy R. The Lure of the Local: Senses of place in a multicentered society. New York: The New Press, 1997.

LIPPARD, Lucy R. Overlay: Contemporary Art and The Art of Prehistory. New York: Pantheon Books,1983.

LIPPARD, Lucy R. "Ana Mendieta 1948-1985 (obituary)". Art in America. November, 1985, p.190.

LYRA, Wilton Luiz Roque. "A quarta dimensão e a arte do século XX". In Intercomunicação entre matemática-ciência-arte: um estudo sobre as implicações das geometrias na produção artística desde o gótico até o surrealismo. [Disponível em: www.teses.usp.br/teses/disponiveis/27/27154/tde-15072009234402/.../5062990.pdf. Acesso em 28 de maio de 2016.

MATISSE, Paul (Org.). Marcel Duchamp Notes. Paris: Centre National d'Art et de Culture Georges Pompidou, 1980.

MARTINO, Ernesto de. The Land of Remorse a Study of Southern Italian Taran- 
tism. London: Free Association Books, 2005.

MILHOMENS, Newton. Fotos Kirlian: A Comprovação Científica. CD-ROM desenvolvido por EGG Tecnologia Ltda. Curitiba - PR. 2000.

NOCHLIN, Linda. "Por que não houve grandes artistas mulheres". [Disponível em: http://www.edicoesaurora.com/ensaios/Ensaio6.pdf]. Acesso em 15 de fevereiro de 2017.

PHELAN, Peggy. Unmarked: the politics of performance. Londres: Routlegde,1993.

POLLOCK, Griselda. "Feminist Interventions in The Histories of Art: An Introduction", In Vison and Difference: Femininity, Feminism and the Histories of Art. Londres: Routledge, 1988, p1-17.

POSNER, Helaine. "The self ande the world: negotiting bounderies in the art of Yayoi Kusama, Ana Mendieta and francesca Woodman". In: CHADWICK, Whitney. Mirror images: woman, surrealismo and self representation. Cambridge: MIT Press, 1998.

PRIORE, Mary Del. AMANTINO, Márcia (orgs.) História do Corpo no Brasil. São Paulo: Editora Unesp, 2011.

PRIORE, Mary Del. "Magia e medicina na Colônia: o corpo feminino". In: PRIORE, Mary Del (org). História das Mulheres no Brasil. São Paulo: Editora Contexto, 2008.

PROCOPIO, Patrizia. "'Danzare Per Fantasmata'. L'immagine Del Movimento Nell'arte Coreutica Del Primo Rinascimento". Accademia Editoriale. [Disponível em: https://www.jstor.org/stable/pdf/24335528.pdf]. Acesso em 30 de agosto de 2016. 
RAIMAN, Karen Cordero; SÁENZ, Ida (org). "Crítica feminista a la teoria e historía del arte". Ciudad de México: CONACULTA, 2001. [Disponível em: https://sentipensaresfem.files.wordpress.com/2016/09/cordero_saenzcomps_critica_feminista_en_la_teoria_e_historia_del_arte2001.pdf]. Acesso em 16 de maio de 2016.

RAINE, Anne. "Embodied geographies: subjectivity and materiality in the work of Ana Mendieta". In: POLLOK, Griselda. Generations and geographies in the visual arts: feminist readings. New York: Routledge,1996.

RIBEIRO, Márcia Moisés. Exorcistas e demônios: demonologia e exorcismos no mundo luso-brasileiro - século XVIII. Rio de Janeiro: Campus, 2003.

ROSSETTI, Victor. "As Deusas Vênus do Paleolítico". [Disponível em: https://netnature.wordpress.com/2016/12/07/as-deusas-venus-do-paleolitico/]. Acesso em 02 de abril de 2018.

RÚíDO, María. Ana Mendieta. Hondarribia: Editorial Nerea, 2002.

SANTOS, Marco Aurélio da Silva. "O Infrassom e o Ultrassom"; Brasil Escola. [Disponível em: https://brasilescola.uol.com.br/fisica/o-infrasom-ultrasom.htm]. Acesso em 28 de maio de 2018.

SCHECHNER, Richard. "O que é performance?" Revista O Percevejo. Tradução Dandara. Rio de Janeiro: UNI-RIO, ano 11, 2003, p.25.50.

SERFATY, Gabriela. Por uma escuta menor. Dissertação de Mestrado (Psicologia Clínica), São Paulo: Pontifícia Universidade Católica de São Paulo, 2016.

SHEVTSOVA, Maria. "In the empire of the object: the geographies of Ana Mendie- 
ta". In: ZOLBERG, Vera L.; CHERBO, Joni Maya. Outsider art: contesting boundaries in contemporary culture. New York: Cambridge University Press, 1997.

SOUZA, Laura de Mello e. "O padre e as feiticeiras: notas sobre a sexualidade no Brasil Colonial". In: VAINFAS, Ronaldo. Historia da Sexualidade no Brasil. Rio de Janeiro: Edições Graal, 1986.

STADEN, Hans. Duas viagens ao Brasil. Belo Horizonte: Itatiaia/ São Paulo: Edusp, 1974.

TAYLOR, Diana. O arquivo e o repertório: performance e memória cultural nas Américas. Belo Horizonte: editora UFMG, 2013.

THOMPSON, Robert Farris. Flash of the spirit: arte e filosofia africana e afro-americana. Tradução: Tuca Magalhães. São Paulo: Museu Afro Brasil, 2011 (1932).

TIBURI, Marcia. ROCHA, Thereza. Diálogo: Dança. São Paulo: Editora Senac, 2012.

TVARDOVSKAS, Luana Saturnino Saturnino. "Corpo e erotismo na obra de Márcia X. [Disponível em: http://www.unicamp.br/chaa/eha/atas/2007/TVARDOVSKAS,\%20Luana\%20Saturnino.pdf]. acesso em 10 abril, 2017.

TVARDOVSKAS, Luana Saturnino. "Rosários e vibradores: interferências feministas na arte contemporânea". In: FUNARI, Pedro Paulo A.; RAGO, Margareth (orgs). Subjetividades antigas e modernas. São Paulo: Annablume, 2008.

VAINFAS, Ronaldo. A heresia dos índios: Catolicismo e rebeldia no Brasil colonial. São Paulo: Companhia das Letras, 1995.

VASCONCELOS, J. "A Natureza Física do Som". In: VASCONCELOS, J. Acústica 
Musical e Organologia. Cap. II. Porto Alegre: Editora Movimento, 2002.

XAVIER, Ismail. O discurso cinematográfico. $3^{\text {a }}$ ed., São Paulo: Paz e Terra, 2005. 


\section{Referências Fílmicas}

A busca pela matéria escura do universo (Curso de verão IFUSP 2018 -palestra 9). Ivone F. M. Albuquerque. 57min.

[Disponível em: http://iptv.usp.br/portal/video.action?idltem=38492. Acesso em 03 de março de 2018.]

A Study in Choreography for Camera (1945). Maya Deren. 2 min 15s. (p\&b) [Disponivel em: https://www.youtube.com/watch?v=3A3caYPInk8. Acesso em 26 de maio de 2014.]

At Land (1944). Maya Deren. 15min. (p\&b).

[Disponível em: https://www.youtube.com/watch?v=DSAdj3phlHU. Acesso em 26 de maio de 2014.]

In the Mirror of Maya Deren (2002). Martina Kudlácek. 1h40min. [Disponivel em: https://www.youtube.com/watch?v=ig5SomdPfAg. Acesso em 17 de maio de 2016.]

Meditation on Violence (1948). Maya Deren. 12 min 30s. (p\&b) [Disponivel em: https://www.youtube.com/watch?v=dIDRMb6YxxM. Acesso em 26 de maio de 2014.]

Meshes of afternoon (1943). Maya Deren. 14min. (p\&b).

[Disponível em: https://www.youtube.com/watch?v=YSYOTA-ttMA. Acesso em 26 de maio de 2014.]

Ritual in Transfigured Time (1946). Maya Deren. 15min. (p\&b) [Disponível em: https://www.youtube.com/watch?v=0IG5K65gkTU. Acesso em 26 de maio de 2014.] 
Tarantula ( La Taranta) (1962). Gianfranco Mingozzi. 18min (p\&b)

[Disponível em: https://www.youtube.com/watch?v=wmbXOdl1yhE. Acesso em 20 de maio de 2016.]

The divine horsemen: vodoo gods of Haiti (1955). Maya Deren. 51 min. (p\&b, mudo).

[Disponível em: https://www.youtube.com/watch?v=RbTggEXG2xU. Acesso em 26 de maio de 2014.]

The very eye of nigth (1952-1955). Maya Deren. 15min. (p\&b)

[Disponível em: https://www.youtube.com/watch?v=rPDWd006Mu4. Acesso em 26 de maio de 2014.] 

Índice de Imagens 

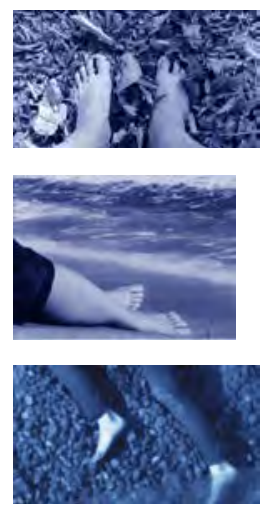

Kim Cavalcante

Still

Intervalo, 2016

Maya Deren

Still

At Land, 1944

Kim Cavalcante

Still

Experimentos de Jardim, 2016
Kim Cavalcante Fotografia (Felipe Gabriel) Experimentos de Jardim, 2016
Kim Cavalcante

Fotografia

Experimentos de Jardim, 2016
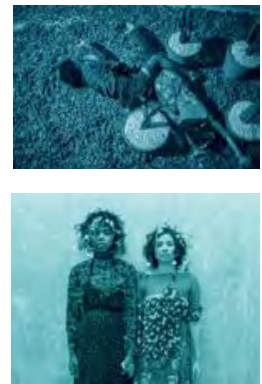

Maya Deren

Still

A Study in Choreography for Camera, 1945

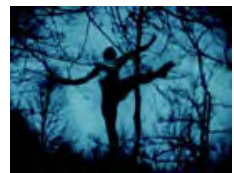




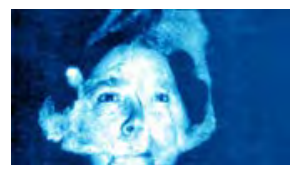

Autor Desconhecido

Fotografia

(ectoplasma saindo de uma médium)

s/ data

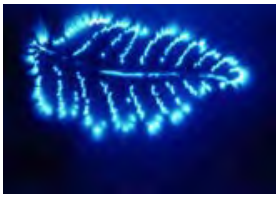

Autor Desconhecido

Fotografia Kirlian

s/ data

Kim Cavalcante Desenho/carta de tarô Artista Feiticeira, 2017

Kim Cavalcante Desenho/carta de tarô Artista Feiticeira, 2017

Kim Cavalcante Fotografia/carta de tarô Artista Feiticeira, 2017

Kim Cavalcante Fotografia Artista Feiticeira, 2017
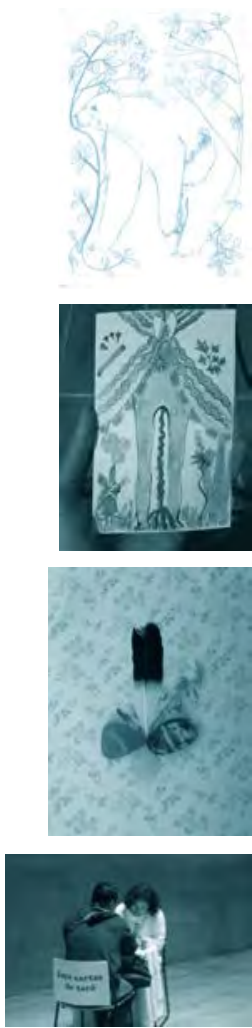

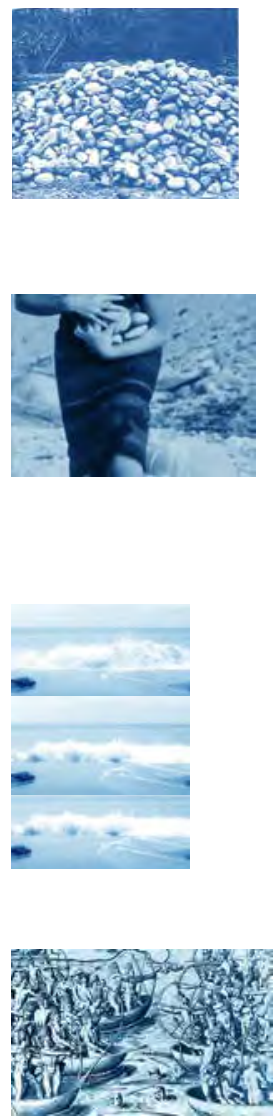

The N. E. Thing Co. ( lain Baxter)

Fotografia

Process Sculptures, 1968

Maya Deren

Still

At Land, 1944

Kim Cavalcante

Stills

Saia Sonora/ O mar não encena, 2016

Theodore De Bry

Desenho

(guerra naval - Hans Satden/ Duas Viagens ao Brasil), 1557 

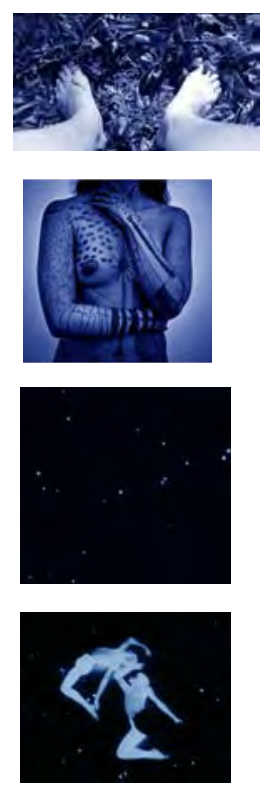

Kim Cavalcante

Still

Intervalo, 2016

Kim Cavalcante

Fotografia ( Guilherme Minoti)

Manto, 2011

Maya Deren

Still

The Very Eye of Nigth, 1955

Maya Deren

Still

The Very Eye of Nigth, 1955
Ana Mendieta

Fotografia

Serie Siluetas, 1978

Kim Cavalcante

Fotografia

Pequeno ensaio sobre o vísivel e o invisível, 2014

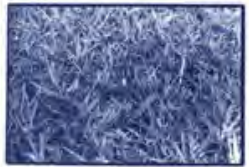


Albert Londe

Fotografia

Mulher histérica gritando, 1890

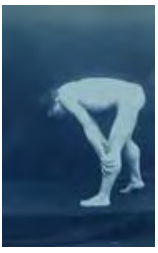

Albert Londe

Fotografia

Document du service photographique de la Salpêtrière, 1893

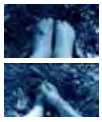

Kim Cavalcante

Stills

Intervalo, 2016

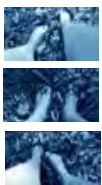

\section{Kim Cavalcante \\ Fotografia \\ Sem Título, 2014}

Athanasius Kircher

Desenho

Dance of the Taranta / Tarantola / Pizzica at Salento / Puglia
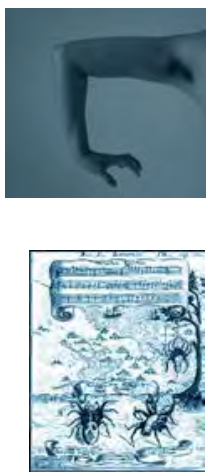

Gianfranco Mingozzi

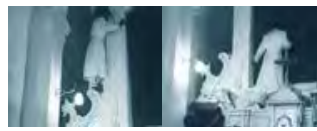



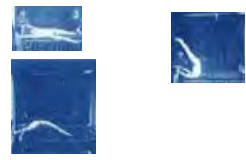

Albert Londe

Fotografia

Histeria/ Salpêtrière, 1885

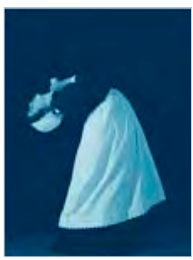

Tejal Shah

Fotografia

Grand Hysteria - Catalepsy -

Iconography from the Salpetrier Series s/ data

\section{Autor Desconhecido \\ Escultura \\ Gauri /Aditi Uttapanad, s/data}

\section{Maya Deren \\ At Land, 1944}

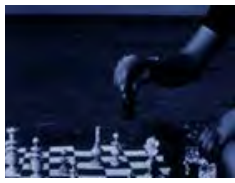

Maya Deren
Still
Meshes of Afternoon, 1943

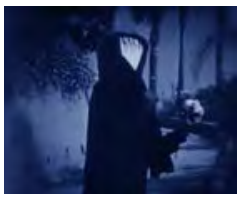

Autor Desconhecido Escultura (chifre de mamute)

Vênus de Hohle Fels, $40.000 / 35.000$ a. C

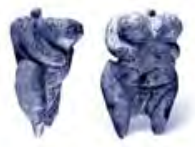

Gianfranco Mingozzi

Stills

Tarantula, 1962

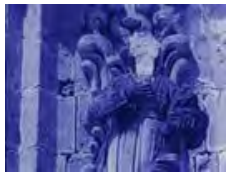




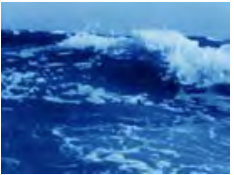

Maya Deren

Still

At Land, 1944
Maya Deren

Still

At Land, 1944

Ana Mendieta

Fotografia

Serie Siluetas, 1978

Kim Cavalcante

Still

Saia Sonora/ O mar não encena, 2016

\section{Kim Cavalcante Objeto}

Saia Sonora, 2013

Kim Cavalcante

Still

Saia Sonora/ O mar não encena, 2016

Gianfranco Mingozzi

Stills

Tarantula, 1962
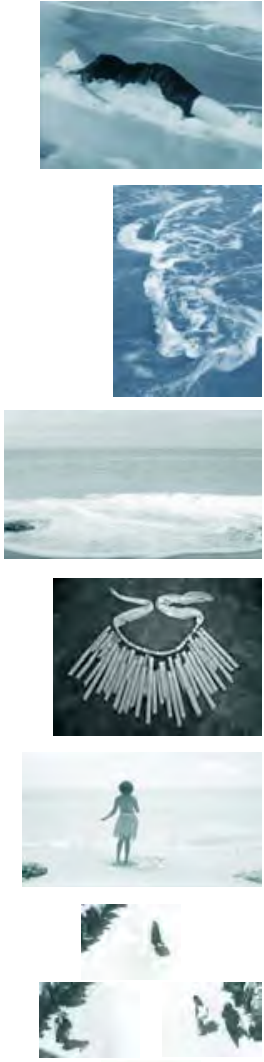

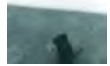



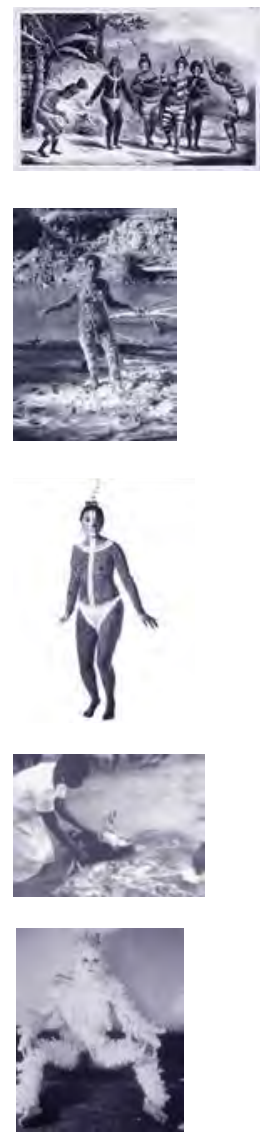

Jean Baptiste Debret

\section{Gravura}

Dança dos Selvagens da Missão de São José, 1834

Ana Mendieta

Fotografia

Blood and Feathers, 1974

Kim Cavalcante

Desenho sobre fotografia

A dança, 2014

\section{Maya Deren}

Still

The divine horsemen: vodoo gods of Haiti, 1955

Ana Mendieta

Fotografia

Bird Transformation, 1975 

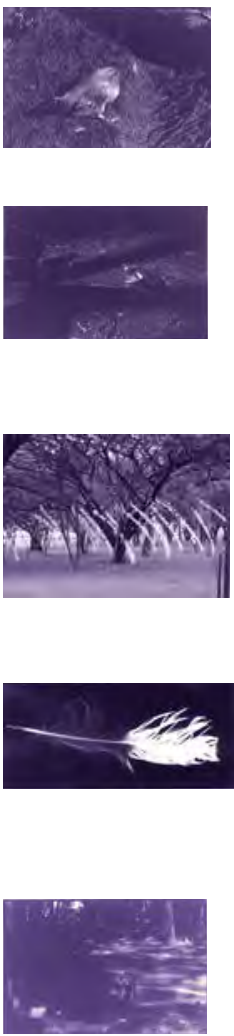

Kim Cavalcante

Fotografia

Pequeno ensaio sobre o vísivel e o invisível, 2014

Kim Cavalcante

Fotografia

Pequeno ensaio sobre o vísivel e o invisível, 2014

Kim Cavalcante

Instalação sonora

Galinhas Voadoras, 2011

Kim Cavalcante

Fotograma

Pequeno ensaio sobre o vísivel e o invisível, 2014

Kim Cavalcante

Fotografia

Pequeno ensaio sobre o vísivel e o invisível, 2014 


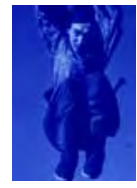

Maya Deren

Still

Meditation n Violence, 1948

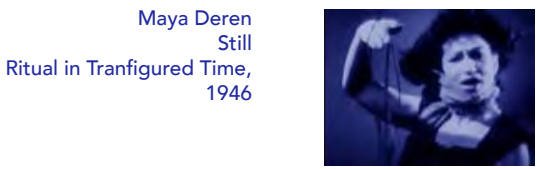

Maya Deren

Still

Meshes of Afternoon, 1943

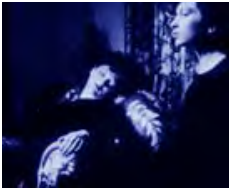

Maya Deren

Still

Meshes of Afternoon, 1943

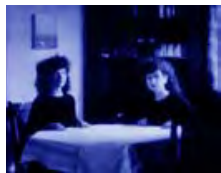

Ana Mendieta

Super 8

Mirage, 1974

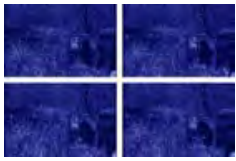

Maya Deren

Still

Ritual in Tranfigured Time, 1946

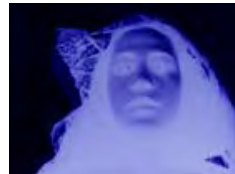



